\title{
Sediment hosted lead-zinc deposits of the Neoproterozoic Bambuí Group and correlative sequences, São Francisco Craton, Brazil: A review and a possible metallogenic evolution model
}

\author{
Aroldo Misi ${ }^{\mathrm{a}, \mathrm{b}, *}$, Sundaram S.S. Iyer ${ }^{\mathrm{c}}$, Carlos Eduardo S. Coelho ${ }^{\mathrm{a}, \mathrm{d}}$, \\ Colombo C.G. Tassinari ${ }^{\mathrm{e}}$, Washington J.S. Franca-Rocha, ${ }^{\mathrm{a}, \mathrm{f}}$, Ioná de Abreu Cunha ${ }^{\mathrm{b}}$, \\ Adriana S. Rocha Gomes ${ }^{\mathrm{b}, \mathrm{g}}$, Tolentino Flávio de Oliveira ${ }^{\mathrm{h}}$, \\ João Batista G. Teixeira ${ }^{a, b}$, Valter Mônaco C. Filho ${ }^{\mathrm{i}}$ \\ ${ }^{\mathrm{a}}$ Grupo de Metalogênese, Centro de Pesquisa em Geofisica e Geologia and Instituto de Geociencias, Universidade Federal da Bahia, \\ Salvador, BA 40170-290, Brazil \\ ${ }^{\mathrm{b}}$ Curso de Pós-Graduação em Geologia, Instituto de Geociências, Universidade Federal da Bahia, Salvador, BA, Brazil \\ ${ }^{\mathrm{c}}$ Department of Physics and Astronomy, University of Calgary, Calgary, Alberta, Canada T2N 1N4 \\ dPetróleo Brasileiro S.A., PETROBRAS-CENPES, Rio de Janeiro, RJ, Brazil \\ ${ }^{\mathrm{e}}$ Centro de Pesquisas Geocronológicas, Instituto de Geociências, Universidade de São Paulo, SP, Brazil \\ ${ }^{\mathrm{f}}$ Universidade Estadual de Feira de Santana, Feira de Santana, BA, Brazil \\ ${ }^{\mathrm{g}}$ Centro de Educação Federal Escola Técnica (CEFET), Salvador, BA, Brazil \\ ${ }^{\mathrm{h}}$ Companhia Mineira de Metais (CMM), Paracatu, Minas Gerais, Brazil \\ ${ }^{\mathrm{i} C o m p a n h i a ~ B a i a n a}$ de Pesquisa Mineral (CBPM), Salvador, Bahia, Brazil
}

Received 1 September 2002; accepted 28 December 2004

Available online 14 April 2005

\begin{abstract}
The Proterozoic sediment-hosted $\mathrm{Zn}-(\mathrm{Pb})$ sulfide and non-sulfide deposits of the São Francisco Craton, Brazil, are partially syn-diagenetic and epigenetic and were probably formed during extensional events. The majority of the deposits occur within shallow water dolomites. The $\mathrm{Pb}$ isotopic data of sulfides are relatively homogeneous for individual deposits and plot above the upper crust evolution curve of the Plumbotectonic model. Some of the deposits are characterized by highly radiogenic lead $\left({ }^{206} \mathrm{~Pb} /{ }^{204} \mathrm{~Pb} \geq 21\right)$ originating from the highly radioactive crust of the São Francisco Craton. $\mathrm{Pb}$ and $\mathrm{S}$ isotopic data suggest the sources of metal and sulfur for the deposits to be the basement rocks and seawater sulfates in the sediments, respectively. The relatively high temperatures of formation $\left(100\right.$ to $\left.250{ }^{\circ} \mathrm{C}\right)$ and moderate salinity $(3 \%$ to $20 \% \mathrm{NaCl}$ equiv.) of the primary fluid inclusions in the sphalerite crystals suggest the participation of basinal mineralizing fluids in ore formation. The steep paleo-
\end{abstract}

\footnotetext{
* Corresponding author.

E-mail address: misi@ufba.br (A. Misi).
} 
geothermal gradient generated by the radioactively enriched basement rocks probably assisted in heating up the circulating mineralizing fluids.

(C) 2005 Elsevier B.V. All rights reserved.

Keywords: Proterozoic $\mathrm{Pb}-\mathrm{Zn}$ deposits; São Francisco Craton; Isotopes; Fluid inclusions; Metallogeny

\section{Introduction}

World class Proterozoic sediment-hosted lead-zinc and/or copper deposits of Africa (Gamsberg, CongoZambia), Australia (Broken Hill, McArthur, Mount Isa-Century), and North America (Sullivan) attest to the metallogenetic importance of the Proterozoic era, during which massive amounts of base metals were deposited in sedimentary basins. Despite this, no giant deposits have yet been discovered in the Proterozoic sedimentary basins of South America, particularly in Brazil, which occupies $50 \%$ of the total continental landmass. This is all the more enigmatic judging from the fact that many base metal deposits, including the world's largest sedimentary copper deposits, occur in the equivalent Neoproterozoic siliciclastic and carbonate sequence of the Katangan province, situated on the African side of Western Gondwana.

The Bambuí Group of Brazil does, however, contain a number of moderate-sized zinc deposits and a large number of smaller deposits and prospects. The genetic character of the deposits range from those of 'Mississippi Valley' to 'Irish Midlands' type, and also include an important zinc-silicate (i.e., non-sulfide) deposit (Vazante). The major deposits of Vazante and Morro Agudo are located along the western border of the São Francisco Craton, and have been mined since 1988 by Companhia Mineira de Metais (CMM). Estimated metal reserves are $18.1 \mathrm{Mt}$ of zinc silicate ore grading $23 \% \mathrm{Zn}$ at Vazante, and $11.7 \mathrm{Mt}$ of sulfide ore grading $6.4 \% \mathrm{Zn}$ and $2.2 \% \mathrm{~Pb}$ at Morro Agudo. The present paper discusses the geology and geochemistry of individual deposits and utilizes this data to develop a metallogenetic model for the area.

\section{Geological and geotectonic setting}

The São Francisco Craton (Fig. 1) is one of the most significant geotectonic units in South America and extends over an area of ca. 1 million $\mathrm{km}^{2}$. During the last decade, investigation and review studies by many researchers (e.g., Dominguez and Misi, 1993; Pedrosa Soares et al., 1994; Barbosa and Dominguez, 1996; Cordani et al., 2000) have significantly improved the level of knowledge about the geological evolution of this craton. The basement to the Proterozoic and Phanerozoic sedimentary basins consists of Archean/Paleoproterozoic medium- to highgrade metamorphic rocks (trondhjemite-tonalitegranodiorite, migmatite, orthogneiss with granitic and mafic/ultramafic intrusions) and volcanosedimentary/greenstone belts (komatiite, tholeiite and calcalkaline rocks, BIF's, chert and sedimentary sequences). The three main sedimentary cover sequences are: (i) Paleo- to Mesoproterozoic Espinhaço Supergroup, with continental felsic volcanic rocks at the base, overlain by sandstone, siltstone and pelite at the mid and upper sections; (ii) Neoproterozoic carbonate and pelitic sequences of the Bambuí Group and their correlatives (the Vazante and the Una Groups); and (iii) Cretaceous siliciclastic sedimentary rocks in the western part of the São Francisco River. The Neoproterozoic carbonate and pelitic sequences host the $\mathrm{Pb}-\mathrm{Zn}$ deposits. Some of the significant geotectonic events and features associated with $\mathrm{Zn}-\mathrm{Pb}$ metallogeny in the Proterozoic basins of the São Francisco Craton are shown in Fig. 2, and are briefly discussed below.

\subsection{The Espinhaço Rift and U-bearing granites of the Paramirim Valley}

The Paramirim Valley divides the São Francisco Craton into two geological domains. The Mesoand Neoproterozoic basins of the Espinhaço Supergroup and Bambuí Group lie on the western side, whereas the equivalent sequences of the Chapada Diamantina and Una Groups occur to the east. The Paramirim Valley itself is $500 \mathrm{~km}$ long and 50 to 


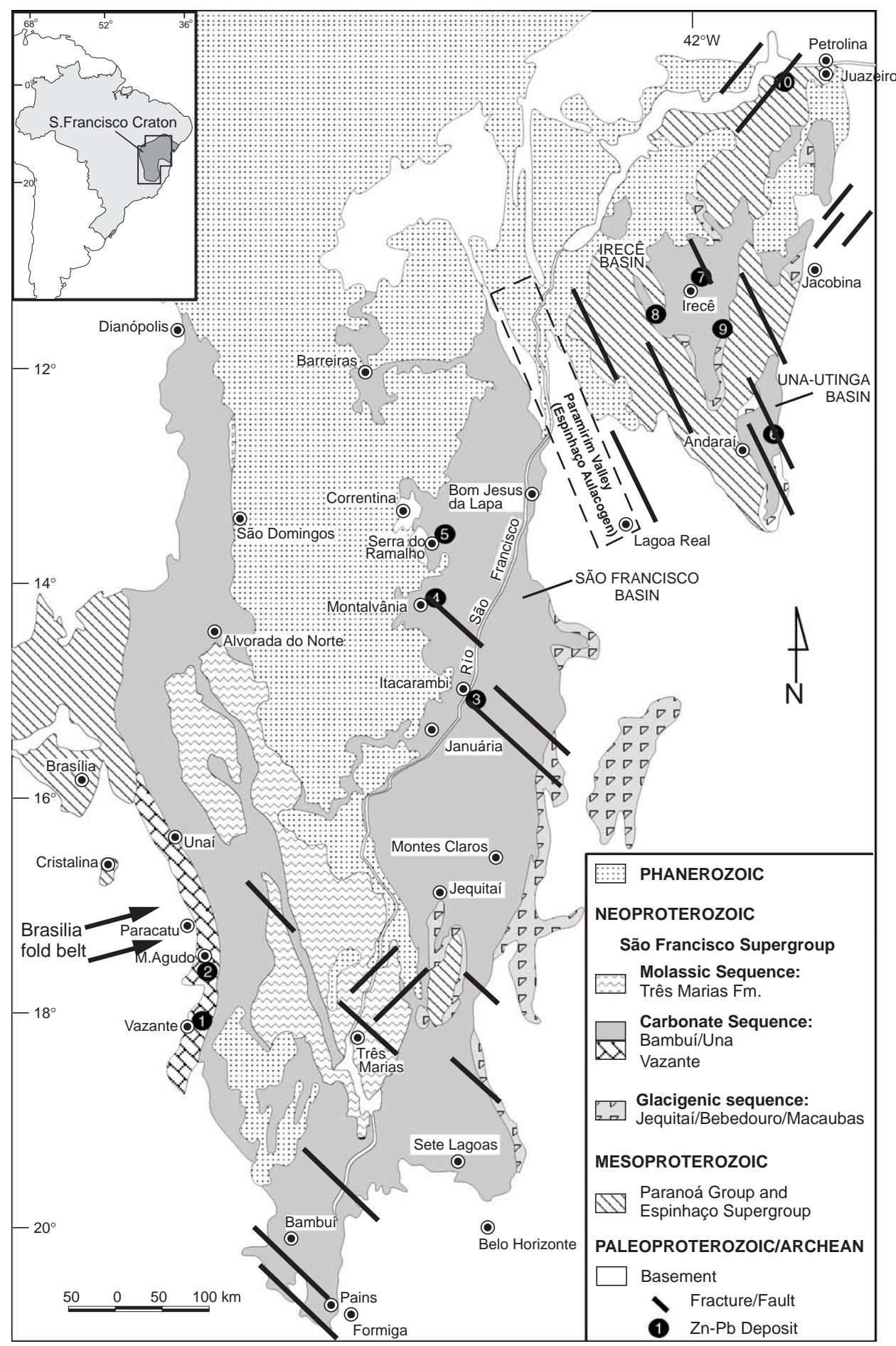

Fig. 1. Geological map of part of the São Francisco Craton displaying the Neoproterozoic basins and the main $\mathrm{Zn}-\mathrm{Pb}$ deposits. (1) Vazante, (2) Morro Agudo, (3) Itacarambí, (4) Montalvania, (5) Serra do Ramalho, (6) Nova Redenção, (7) Irecê, (8) Morro do Gomes, (9) Melancias, (10) Caboclo (Mesoproterozoic). Modified after Schobbenhaus et al. (1981). 


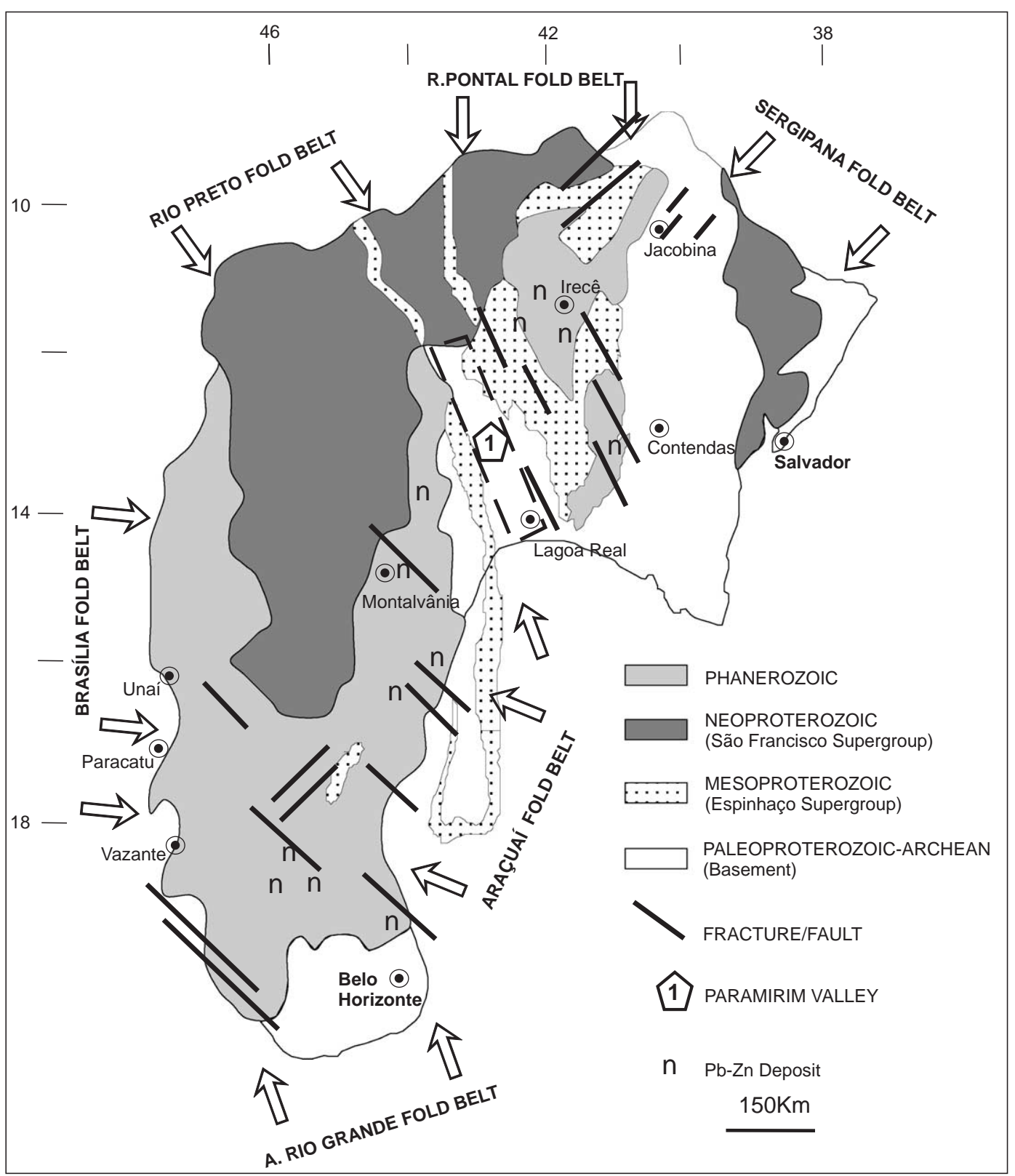

Fig. 2. Simplified geological map of the São Francisco Craton, showing the $\mathrm{Zn}-\mathrm{Pb}$ deposits and occurrences, the main geotectonic features and the locations referred to in the text.

$100 \mathrm{~km}$ wide and trends NNW-SSE. The valley rests on an Archean/Paleoproterozoic terrane composed of migmatite, granite and metamorphosed sedimentary and volcanic rocks. The Paramirim structure was formed during an important extensional event marked by the emplacement of alkaline to sub-alkaline igneous complexes, including A-type granites. A tectonic inversion aborted the evolution of the rift. Diverse isotopic dating techniques, including $\mathrm{U}-\mathrm{Pb}$ on detrital zircons, yielded dates between 1.76 and $1.8 \mathrm{Ga}$ (Turpin et al., 1988; Machado et al., 1989; Cordani et al., 1992; 
Babinski, 1993) for the intrusive granites (Lagoa Real Complex) and volcanic flows (Rio dos Remédios Group).

The rocks of Lagoa Real granite-orthogneiss complex are highly enriched in radioactive elements, with concentrations of $\mathrm{U}$ and Th ranging from 4 to 20 and 15 to 76 ppm, respectively (Maruéjol et al., 1987). Extensive mobilization by late metasomatic solutions within the Lagoa Real complex led to accumulation of economic U-deposits, which are currently mined. The high radiogenic heat production of the granites appears to have induced high heat flow, resulting in a steep paleo-geothermal gradient. Such a gradient may have facilitated the setting up of a high temperature convective system in the Neoproterozoic basins (see below).

\subsection{The Pan African-Brasiliano Tectonic Cycle and the Neoproterozoic sedimentary basins}

The Pan African-Brasiliano orogeny consists of several orogenic events spanning from ca. 850 to 490 $\mathrm{Ma}$, reaching a climax between 600 and $550 \mathrm{Ma}$ ago (Almeida and Hasui, 1984; Brito Neves et al., 2000). Deposition of the Neoproterozoic sedimentary sequences hosting $\mathrm{Zn}-\mathrm{Pb}$ deposits in the São Francisco Craton took place during extensional events marking the fragmentation of the Rodinia supercontinent, between 750 and $600 \mathrm{Ma}$. Condie (2002) has suggested that the sequence leading to formation and breakup of Rodinia, and the subsequent assembly of Gondwana is a cycle with a probable overlap of $100 \mathrm{Ma}$ between each stage. Porada (1989) and Brito Neves et al. (2000) described the diachronic history of the Pan African-Brasiliano orogeny in the African and South American continents.

The two important geotectonic mega-units of the Neoproterozoic sedimentation in the São Francisco Craton are as follows. (A) Carbonate platform sequences in the central part, forming the São Francisco, Irecê and Una-Utinga Basins (Bambuí and Una Groups). (B) Passive margin carbonate and siliciclastic sequences forming intensely deformed units in the fold belts surrounding the craton. The Brasília Fold Belt, with the Vazante Group, lies on the western border of the São Francisco Craton. Brito Neves (1975), Dardenne (1978, 2000), Misi (1976, 1999, 2001), Dardenne and Freitas-Silva (1998), and
Misi et al. (1998, 1999) have demonstrated possible sequence correlation between the sedimentary units deposited in these two distinct tectonic settings.

The following assemblages constitute the Neoproterozoic sequences of the São Francisco Craton (Fig. 1):

Glacigenic units, consisting predominantly of diamictite, conglomerate, pelite and quartzitic (arkosic) lenses of the Jequitaí, Macaúbas, and Bebedouro Formations. Minor glacio-marine and fluvial sedimentary rocks occur in this sequence. In the passive margin basin of the Brasilia Fold Belt, Dardenne $(2000,2001)$ observed diamictites at the base (Santo Antonio do Bonito Formation, Vazante Group), possibly equivalent to the Jequitaí Formation (Bambuí Group, base).

Carbonate and pelitic units, comprised of limestone, dolostone, marl, shale and siltstone. In the São Francisco Basin, the Neoproterozoic sedimentary sequence is known as the Bambuí Group and contains carbonate sedimentary rocks of the Sete Lagoas and Lagoa do Jacaré Formations, interpreted as deposited in a warm and shallow shelf environment. The correlative unit of the Bambuí Group in the Irecê and Una-Utinga Basins is the Salitre Formation of the Una Group. Along the marginal fold belts, particularly in the Brasilia Fold Belt, the carbonate sedimentation is thicker, reaching up to $2 \mathrm{~km}$ of dolostones in the Vazante Group. Molasse-type strata: consisting of arkosic sandstone, siltstone, phyllite and conglomerate, probably related to the evolution of a "molasse-type" basin (Thomaz Filho et al., 1998). In the Minas Gerais State they are represented by the Três Marias Formation.

The most significant radiometric age constraints available for the Neoproterozoic sediments can be summarized as follows. A U-Pb SHRIMP age of 950 Ma was obtained for the detrital zircons extracted from basal diamictite of glacio-marine origin within the Araçuaí fold belt. This may be considered the maximum age limit of the glaciation; Pedrosa Soares et al. (2000) linked this age to the Neoproterozoic rift magmatism. Rb-Sr age determinations (Macedo, 1982; Macedo and Bonhomme, 1984) suggest a time interval of $932 \pm 30$ to 
$667 \pm 30$ Ma for deposition of the glacigenic basal sediment. $\mathrm{Rb}-\mathrm{Sr}$ isotopic dating of pelitic sedimentary rocks (Macedo, 1982; Macedo and Bonhomme, 1984) suggest a time interval of 770 to $560 \mathrm{Ma}$ for deposition of the carbonate sequence above the glacigenic units. The $\mathrm{Pb}-\mathrm{Pb}$ isochron age $(740 \pm 22$ $\mathrm{Ma} ; \mathrm{MSDW}=0.66$ ) from well-preserved carbonates of the Bambuí Group, interpreted as the depositional age (Babinski and Kaufman, 2003). Chemostratigraphic studies of the carbonate units (Misi et al., 1997; Chang, 1997; Misi and Veizer, 1998; Azmy et al., 2001; Misi, 2001) support the sequence correlation discussed above. In these studies, ${ }^{87} \mathrm{Sr} /{ }^{86} \mathrm{Sr}$ data of well-preserved carbonate samples indicate a possible age of sedimentation close to $700 \mathrm{Ma}$, by comparing with seawater global composition based on extremely well-preserved sediments, permitting the construction of $\mathrm{Sr}$ isotope age curves of great confidence (cf. Jacobsen and Kaufman, 1999; Brasier and Shields, 2000).

During the evolution of these carbonate and pelitic sequences, a minimum of two major sedimentary cycles (Fig. 3) appear to have occurred predominantly in the non-folded platform sequences within the cratonic area (Misi, 1999).

The first of these (Cycle 1) was a transgressiveregressive event resulting in a typical shallowing upward sequence. This cycle starts in the basal portion of the carbonate platform sequence of rythmites made of limestone with interbedded clay material deposited over the glacigenic units. The upper most part of the sequence is composed of dolomites with tepee structures and cyanobacterial mats, suggesting a regional subaerial exposure of the carbonate platform. The leadzinc deposits are associated with this dolomitic unit (Dardenne, 1978, 2000; Misi, 1978, 1999) and with syn-sedimentary normal faults at Vazante and Morro Agudo (Hitzman, 1997; Dardenne, 2000; Misi et al., 2000) and fractures aligned NNW-SSE (see below).

Cycle 2 was a transgressive event, where the presence of black shale and marl immediately above the dolomitic units of Cycle 1 indicates a regional subsidence of the basin related to extensional processes. Organic-rich oolithic and pisolitic limestone at the top, indicate deposition in shallow agitated waters by tidal currents.

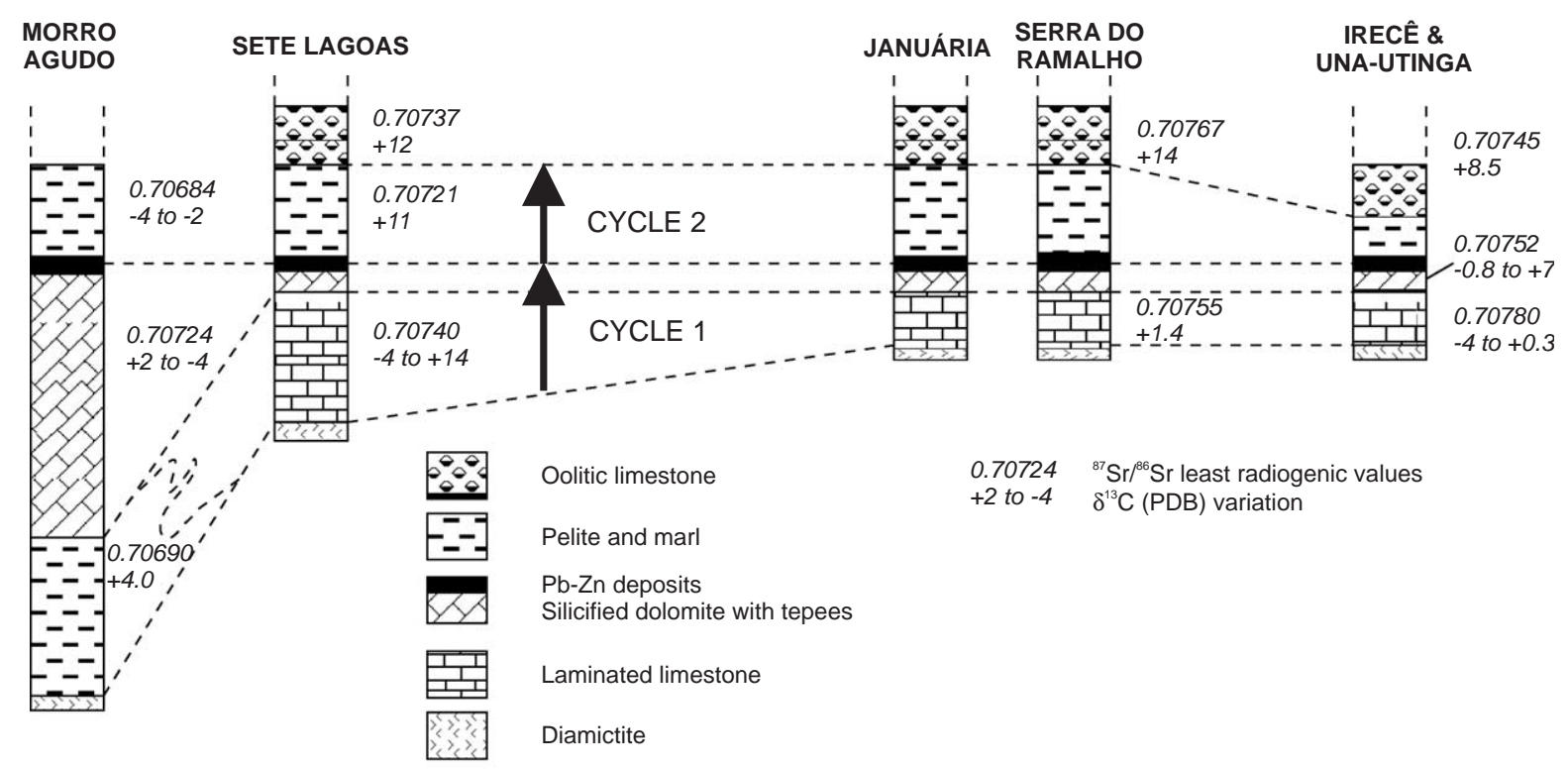

Fig. 3. Sedimentary cycles in the Neoproterozoic sedimentation, São Francisco Craton. Note the sequence correlations (supported by chemostratigraphic investigation) and the location of the $\mathrm{Zn}-\mathrm{Pb}$ deposits controlled by a sequence boundary. Modified after Misi (2001). 


\subsection{Structural lineaments}

The structural lineaments (fractures and faults) that cross the Pre-Neoproterozoic basement and the Neoproterozoic sedimentary cover, as well as the associated growing faults observed in the sedimentary basins, suggest that the tectonic regime active in the Paleoproterozoic basement probably continued during the sedimentation of the Espinhaço Supergroup and Bambuí Group and equivalents. Two main trends of structural lineaments occur in the cratonic area are (Figs. 1 and 2). The first of these, trending NNW-SSE in the Vazante-Paracatú and Sete Lagoas areas (Minas Gerais), Serra do Ramalho and Chapada Diamantina (Bahia), shows a close association with the $\mathrm{Pb}-\mathrm{Zn}$ deposits and occurrences. In Morro Agudo mine (Paracatu), orebodies are associated to syn-sedimentary normal faults trending $\mathrm{N} 10-20^{\circ} \mathrm{W}$, in which the main fault was demonstrated to be a feeder zone to the deposit (Misi et al., 1999). The second, trends NNE-SSW in the Chapada Diamantina area and crossing the Mesoproterozoic sequences. Conceição Filho et al. (1993), Franca Rocha and Misi (1993) and Misi (1999) demonstrated the association of the Caboclo $\mathrm{Pb}-\mathrm{Zn}$ mineralization (the only known sulfide deposit within Mesoproterozoic sedimentary rocks of the São Francisco Craton) with these structures, which are considered to be extensional faults. Both sets of structures crosscut the PreNeoproterozoic basement and the Neoproterozoic sequences.

\section{The zinc-lead deposits}

$\mathrm{Zn}-\mathrm{Pb}$ deposits of the São Francisco Craton are distributed over an area $>300,000 \mathrm{~km}^{2}$. Their main characteristics are described below. Only two deposits (Morro Agudo and Vazante) are currently mined.

\subsection{Morro Agudo}

The Morro Agudo and the Vazante mines, as well as several other $\mathrm{Zn}-\mathrm{Pb}$ deposits, occur on the western border of the São Francisco Basin, within the east verging Brasilia fold belt (Fig. 4). The Morro Agudo mineralization is stratigraphically disposed and controlled by a fault system (Fig. 5). The deposit is lithostratigraphically confined to dolarenites and pink dolomites of the Morro do Calcário Formation with black carbonaceous slate on top (Lapa Formation). Very shallow water sedimentation is shown by mud cracks (Fig. 6A) and barite nodules. Dardenne (1978) defined these units as belonging to the "Vazante Formation", formed of two regressive megacycles separated by a transgressive event attested by the pelite-carbonate succession. Such cyclicity is very similar to that observed in the Bambuí and Una Groups within the cratonic area (Misi, 1978; Dardenne, 1978; Marini et al., 1981). These units vary in thickness with southern parts of the Vazante mine reaching $>2500 \mathrm{~m}$.

The age of sedimentation has been a matter of controversy for many years. Although most researchers considered the Vazante to be a non-cratonic folded counterpart of the Bambuí Group, Dardenne $(1978,1979)$ did not find lithostratigraphic correlation with the typical cratonic Bambuí sequences and suggested a Mesoproterozoic age for the Vazante Formation. However, chemostratigraphic studies based on ${ }^{87} \mathrm{Sr} /{ }^{86} \mathrm{Sr}$ determinations of well-preserved carbonate samples (organic, micritic limestone) and of phosphorites from the Una and Bambuí/Vazante sequences indicate a Neoproterozoic age for the carbonate sedimentation (Misi et al., 1997; Azmy et al., 2001; Misi et al., 2003).

Dardenne $(2000,2001)$ established a new stratigraphic order for the Vazante sequences, classifying them as a Group (the Vazante Group) made up of diamictite beds, quartzite, slate and phosphorite bearing basal unit (Retiro or Santo Antonio do Bonito Formation). According to Dardenne, some of these lithotypes are "very similar to those in the Jequitaí Formation" and thus may be correlated to the Bambuí Group" (Dardenne, 2000, p. 247).

In Morro Agudo, the sulfide mineralization (sphalerite, galena and minor pyrite) is associated with calcite, microquartz (length slow), megaquartz and barite. Both the massive and disseminated ore deposits are distributed along a fault zone. These are subdivided into four main types by local mine geologists (Fig. 5; Romagna and Costa, 1988) as follows. The M orebody consists of coarse-grained galena and sphalerite forming veins in dolarenites. 


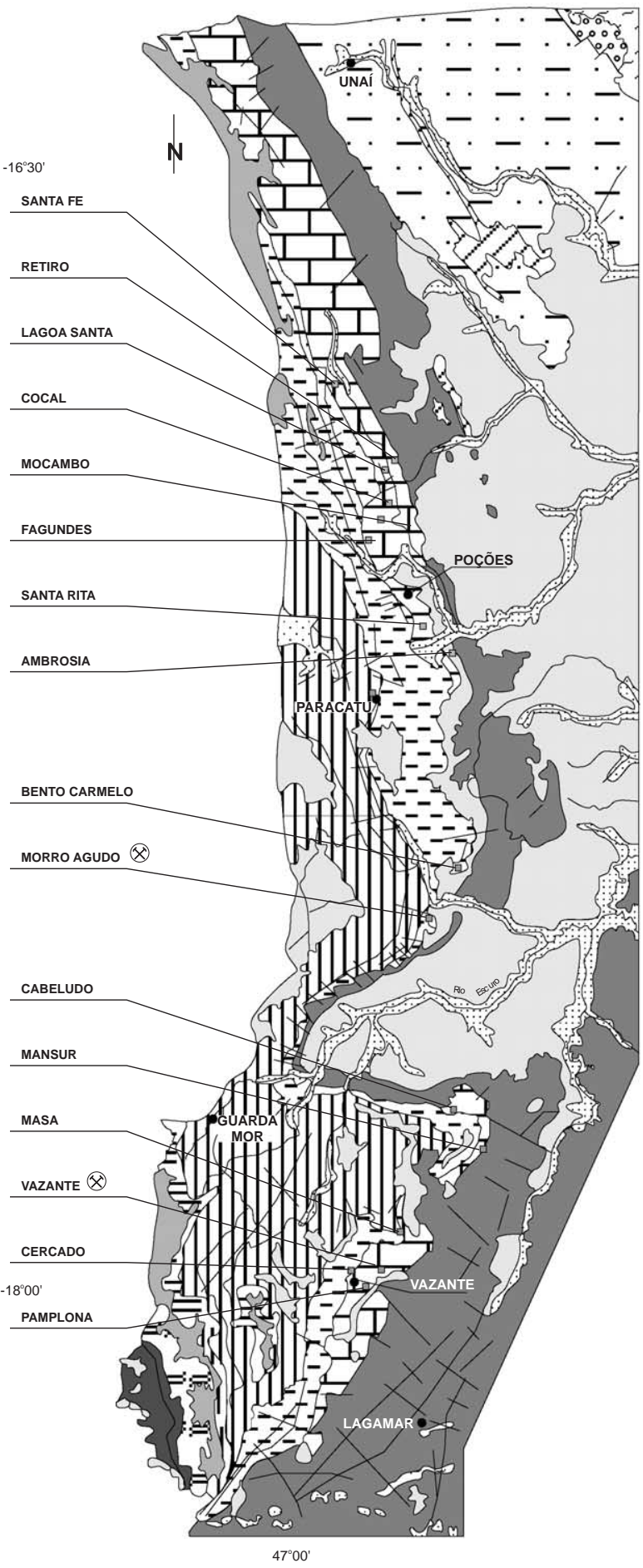

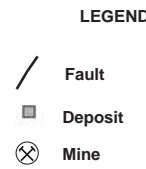

PHANEROZOIC

ALLUVIAL

QUATERNARY PLEISTOCENE

TERTIARY

- UPPER CRETACEOUS

NEOPROTEROZOIC

$\because$ TRESSMARIAS

$\left[\begin{array}{l}\square \\ \square\end{array}\right]$ unaí sequence

DI PARACATU

-- $\quad$ LAPA FORMATION

VAZANTE DOLOMITES

S. DO GARROTE
FORMATION

IBIÁ FORMATION

$\square$ UPPER SANDSTONE

E Lower sandstone

Fig. 4. Geological map of the Vazante-Unaí trend showing the Vazante Formation with the $\mathrm{Zn}-\mathrm{Pb}$ deposits. After unpublished data of CMM. 


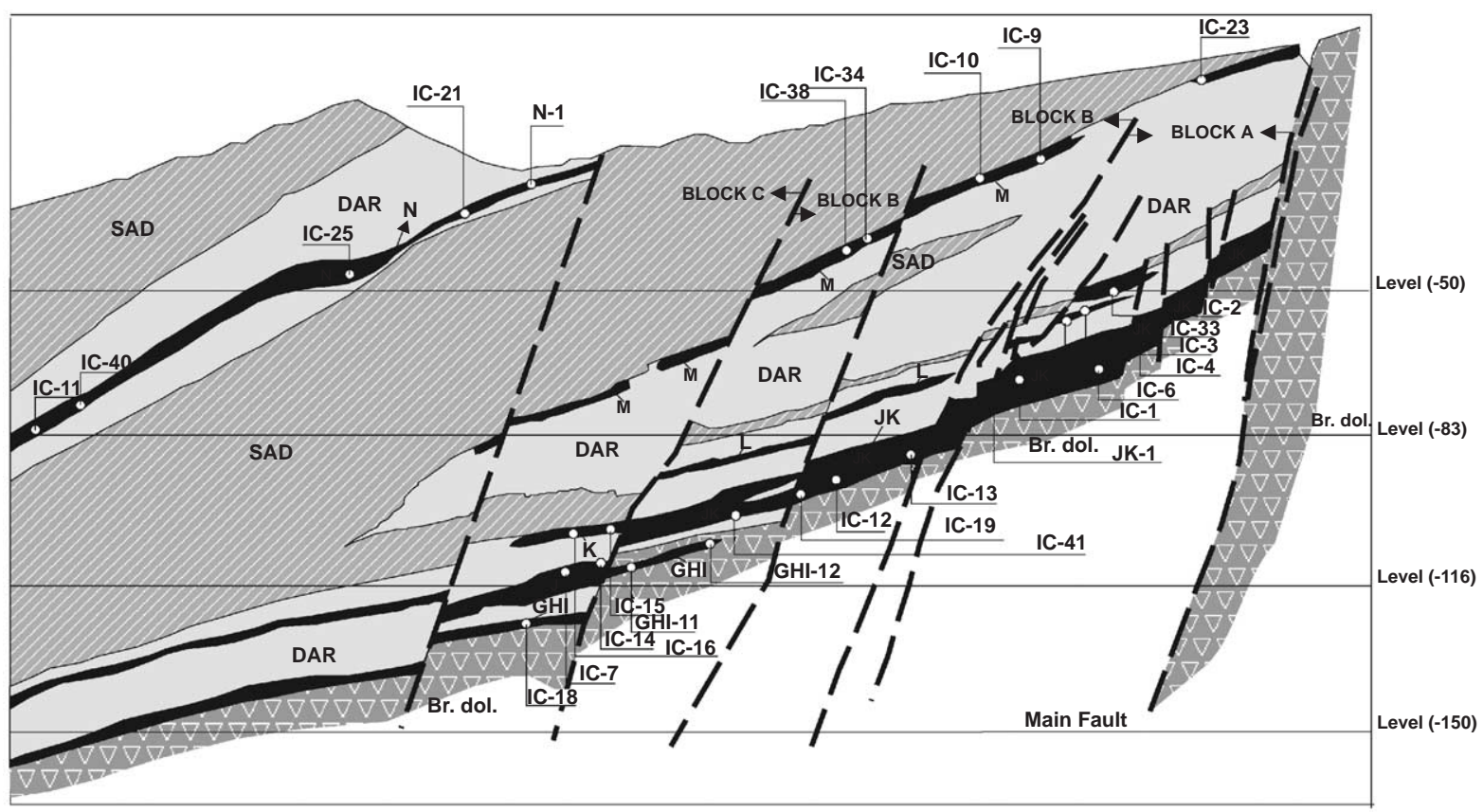

LEGEND
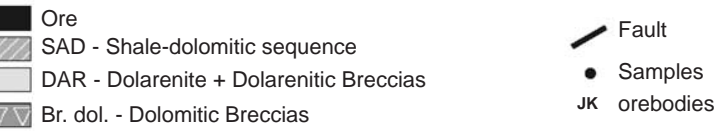

Fig. 5. W-E cross section in the Morro Agudo deposit across the mine blocks A, B, C and D showing the distribution of the ore bodies in relation to the main fault and the location of the samples used for isotopic and fluid inclusions studies. After unpublished data of CMM and Cunha (1999).

The $\mathrm{N}$ orebody is composed of fine-grained, stratiform mineralization in dolarenitic beds. Alternate lamina of chert, galena, sphalerite and pyrite and the presence of $\mathrm{mm}$-scale beds of ultra-fine sphalerite, silica nodules deforming sphalerite laminae (Fig. 6C) and sulfide nodules (Fig. 6D) suggest a syngenetic to syndiagenetic mineralization within this orebody. The JKL ore body consists of massive fine- to coarse-grained sulfides (mainly sphalerite), cementing oolitic dolostone beds (Fig. 6E) and the GHI ore body consists of coarse-grained sphalerite and galena cementing brecciated structures (Fig. 6F). The occurrence of nodular sulfides associated with microcrystalline, fibrous quartz in the $\mathrm{N}$ orebody suggests that an earlier evaporate condition controlled part of the stratiform mineralization.

The main fault, as labelled by mine geologists at Morro Agudo, is a normal fault trending N $10-20^{\circ} \mathrm{W}$ and dipping $75^{\circ} \mathrm{W}$. All the ore bodies are located to the west of the fault zone; barren stromatolitic and brecciated dolostones occur to the east (Fig. 5). Sulfur isotopic data of 36 sulfide samples from the different orebodies show a decrease of $\delta^{34} \mathrm{~S}$ values from the fault zone towards the west implying a possible feeder zone associated with the fault system.

\subsection{Vazante}

The Vazante deposit, $80 \mathrm{~km}$ south of Morro Agudo, is currently the most significant $\mathrm{Zn}$ mine in Brazil. Unlike other deposits, the ore has been oxidized and consists mainly of willemite $\left(\mathrm{Zn}_{2} \mathrm{SiO}_{4}\right)$, with lesser hemimorphite, hydrozincite, smithsonite and pyromorphite. Stratigraphic control of the primary mineralization at Vazante was demonstrated by Monteiro et al. (1999). Willemite and sulfide concentrations are restricted to the upper part of the 

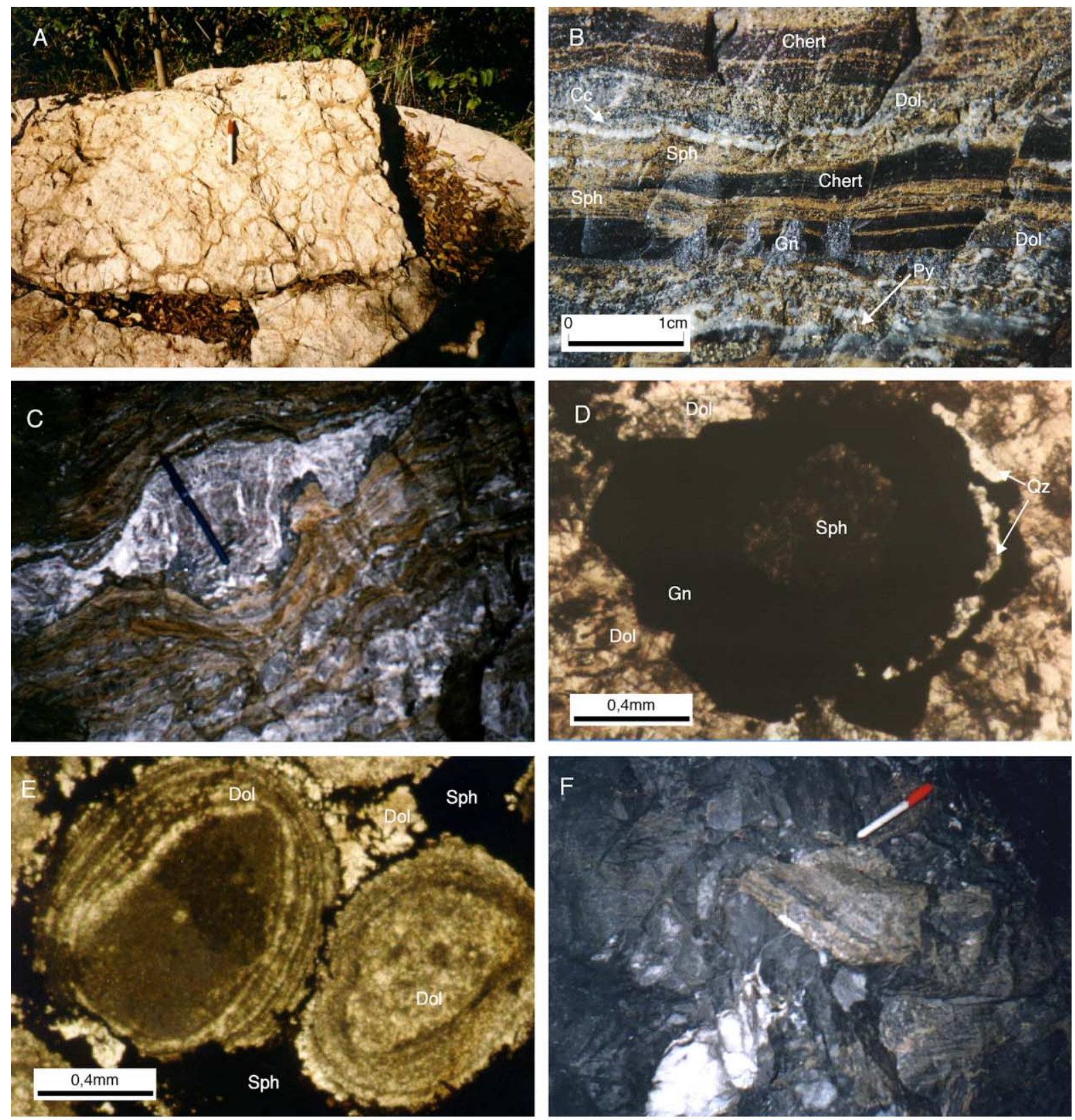

Fig. 6. Macro- and microscopic features in the orebodies and in the host rocks at the Morro Agudo mine. (A) Dolostone with mud-cracks at the Pamplona Member (Vazante Formation). (B) Massive stratiform mineralization at the N orebody, Morro Agudo deposit, formed by millimetric layers of chert, dolomite (Dol) and fine grained sphalerite (Sph), with patches of galena (Gn) and pyrite (Py) and with calcite veins (Cc). (C) Silica nodule (microquartz) at the N orebody, Morro Agudo mine. Sphalerite and dolostone beds are deformed during growth of the nodule. (D) Complex sulfide nodule in dolostone, formed by sphalerite ( $\mathrm{Sph}$ ) surrounded by galena $(\mathrm{Gn})$, probably replacing a sulfate nodule. The presence of length-slow quartz (Qz) suggests that the silica replaced sulfate minerals in the dolostone (gypsum?). N orebody, Morro Agudo mine. (E) Massive coarse grained sphalerite replacing oolithic dolarenite, JKL orebody, Morro Agudo mine. (F) Breccia-type sphalerite mineralization, GHI orebody, Morro Agudo mine. 

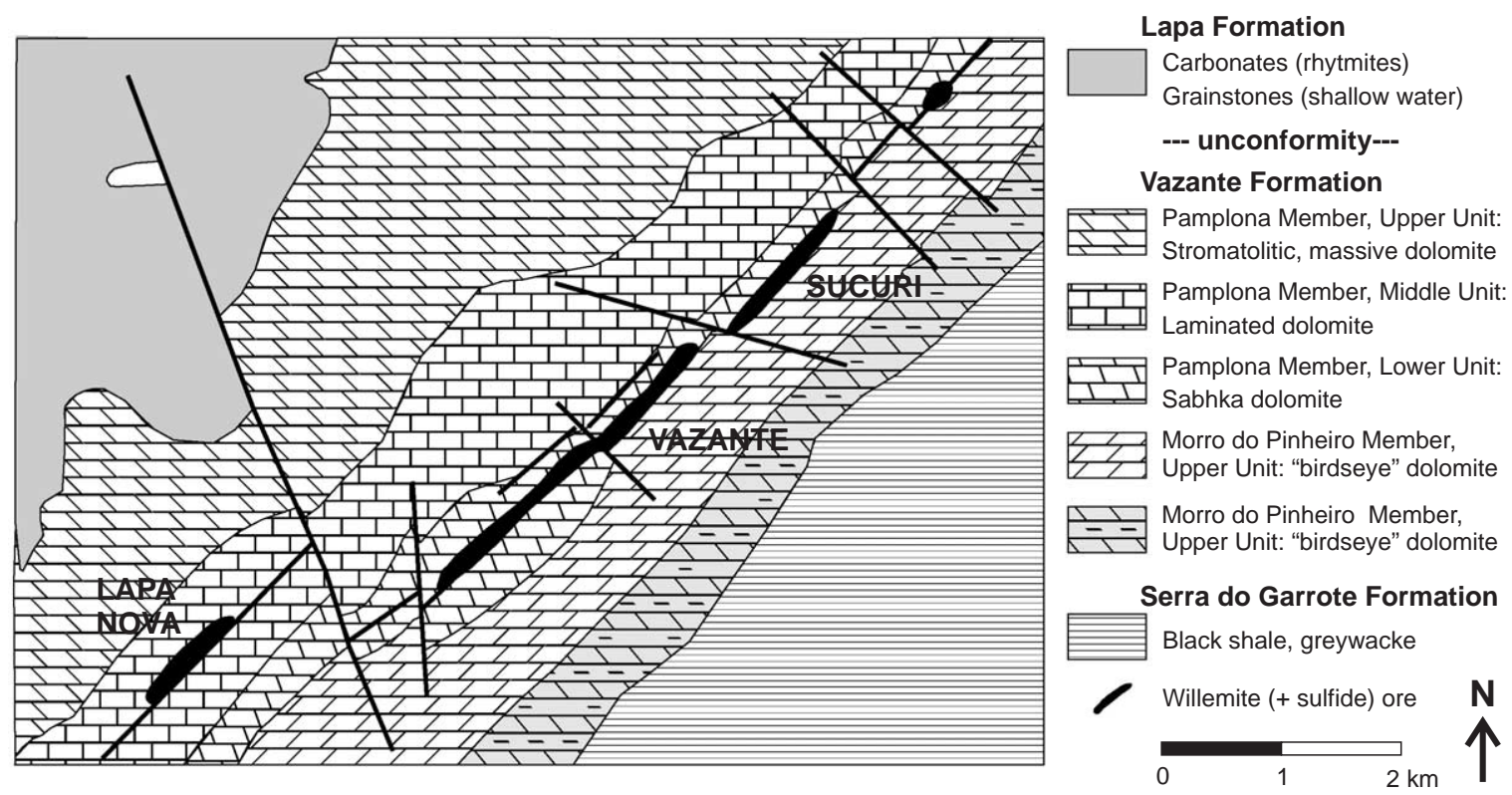

Fig. 7. Geology of part of the Vazante mine. After unpublished data of CMM geologists.

Morro do Pinheiro Member (Monteiro et al., 1999). Geological characteristics of the Vazante mine and a cross-section of a typical ore zone are shown in Figs. 7 and 8. A fault zone (the Vazante Fault), subparallel to the regional strikes of the rocks, appears to control the ore deposition (Fig. 8). According to Dardenne (2000), the structural system was originally related to a syn-sedimentary growth fault, reactivated several times during the Brasiliano orogeny. Hitzman (1997) observed that, despite the general trend of the normal fault, final movement of the Vazante fault was reverse sense, as evident from several kinematic indicators.

Mineralization at Vazante largely occurs in NEtrending and NW-dipping $\mathrm{cm}$ - to $\mathrm{m}$-wide veins along a fracture zone (Hitzman, 1997). In these veins, willemite mineralization is associated with hematite, zincite, franklinite, sphalerite and galena. The host dolomite is hydrothermally altered (silicification and sideritization), with both mineralization and hydrothermal alteration zones apparently controlled by faults. The veins with hematite and silica formed during the evolution of the normal faults. According to Hitzman (1997), the transposition of the movement (extensional to compressional) led to the appearance of reversed faults that disrupted the veins as well as the hydrothermally altered layers of dolomites.

The sulfide mineralization at Vazante includes small irregular bodies and veins of sphalerite with minor galena and devoided of pyrite and pyrrhotite. SEM images of euhedral contacts of willemite with sphalerite with which it is intergrown led Hitzman (1997) to suggest co-precipitation of willemite and coexisting sulfides. Oxygen and carbon isotopic composition of the gangue minerals led Monteiro (1997) and Monteiro et al. (1999) to the conclusion that the oxy-reduction conditions for sulfide and willemite mineralization were similar.

\subsection{Irecê Basin}

The Irecê Basin comprises of a $1.2 \mathrm{~km}$ thick, predominantly carbonate (Salitre Formation), lying unconformably above glacigenic sedimentary rocks (diamictites) of the Bebedouro Formation. Mesoproterozoic siliciclastic metasedimentary rocks of the Chapada Diamantina Group (Fig. 1) lie at the base of this formation. Misi (1978) identified two transgressive-regressive cycles in the carbonate package of the Irecê Basin. A sedimentation age interval of 670 to $600 \mathrm{Ma}$ was proposed by Misi and Veizer 


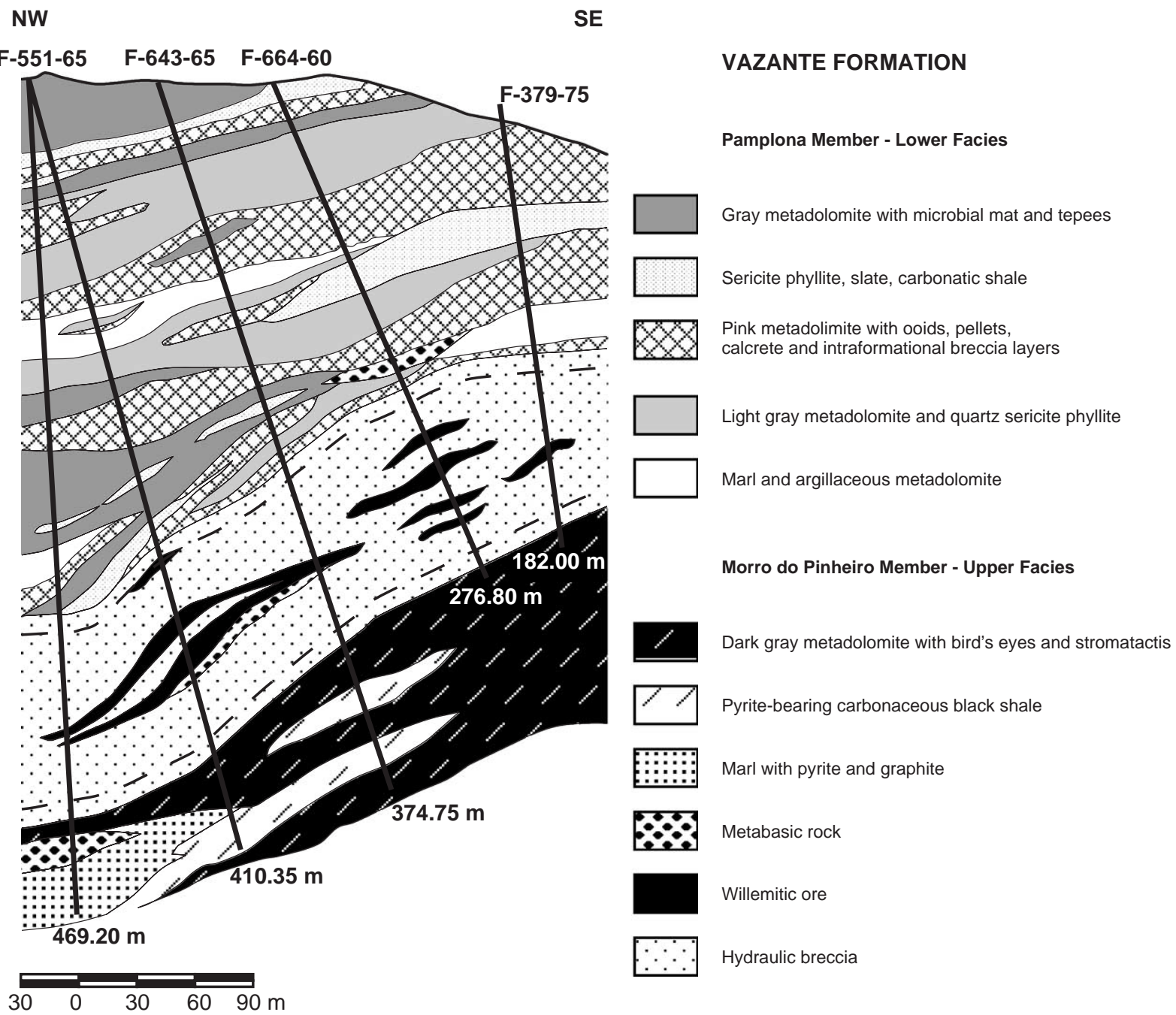

Fig. 8. Cross-section of a typical ore zone in the Vazante mine. After Monteiro et al. (1999).

(1998) from ${ }^{87} \mathrm{Sr} /{ }^{86} \mathrm{Sr}$ data of well-preserved carbonates of the Irecê Basin. The Salitre Formation hosts several small stratigraphically controlled $\mathrm{Pb}-\mathrm{Zn}$ deposits, including Melancias, Morro do Gomes and Rufino or Três Irmãs (Fig. 1). With the exception of Morro do Gomes, the others are associated with stromatolitic silicified dolomites overlying a shallowing-upward sequence (Unit B1). The orebodies are stratiform, stratabound and discordant, and contain nodular barite, calcite and microcrystalline, length slow quartz. Massive galena aggregates occur along with megaquartz and calcite veins in the Morro do Gomes deposit.
In 1979, a small $\mathrm{Zn}-\mathrm{Pb}-\mathrm{Ag}$ sulfide mineralization (the Rufino or Três Irmãs deposit) was discovered in the central part of the Irecê Basin by Riofinex do Brasil during drilling close to a gossan occurrence. In the mid-1980s, stromatolitic phosphate concentration was discovered in the same area by the Geological Survey of Brazil (CPRM) and the Superintendência de Geologia e Mineração (SGM, the former Geological Survey of Bahia State)). Monteiro (1989) estimated the sulfide ore reserves to be $1.5 \mathrm{Mt}$ at an average grade of $8 \% \mathrm{~Pb}+\mathrm{Zn}$ and $120 \mathrm{~g} / \mathrm{t} \mathrm{Ag}$. Stratabound sulfide mineralization and phosphate concentration occur within a $50 \mathrm{~m}$ thick 
tidal flat sequence of the Salitre Formation (Figs. 9 and 10). The phosphate mineralization (mainly carbonate fluorapatite) is at a slightly lower stratigraphic position in relation to the sulfide ore zone. Investigations of Misi and Kyle (1994) revealed that phosphate-bearing columnar stromatolitic structures in dolostone were formed in sub- to intertidal zones and that carbonate fluorapatite was formed during the early diagenetic evolution of the carbonate sediments.

The association of stratabound massive and disseminated sulfide mineralization in the Rufino deposit with dolostone formed in a shallow-water sedimentary environment (Fig. 11A) (Kyle and Misi, 1997). Finegrained dissemination, laminae, lenses, irregular masses, nodular aggregates (Fig. 11C, D, F), and breccia and fracture-filling sulfide minerals (pyrite, sphalerite, galena, marcasite, jordanite, tetrahedrite and covellite) are associated with dolomite, calcite, microquartz (fibrous, length-slow), barite, baroque dolomite, gypsum and megaquartz (Kyle and Misi, 1997). Replacement textures are common in the sulfides, with pyrite crystal aggregates showing bladed forms (Fig. 11B, E), pseudomorphs after gypsum.

\subsection{Nova Redenção (Una-Utinga Basin)}

The Una-Utinga Basin is filled with predominantly carbonate sequences and the stratigraphic structure is similar to that of the Irecê Basin. Diamictites of the glacigenic Bebedouro Formation are unconformably overlain by limestone and dolomitic limestones, which occupy a stratigraphic position equivalent to those of the Salitre Formation, in the Irecê Basin. The $\mathrm{Pb}-\mathrm{Zn}$ (Ag) mineralization in Nova Redenção is in direct association with silicified oolitic dolarenites and dolomitic breccia that correspond to the uppermost section of a shallowing-upward sequence. Despite the intensive silicification, these dolomitic beds seem to
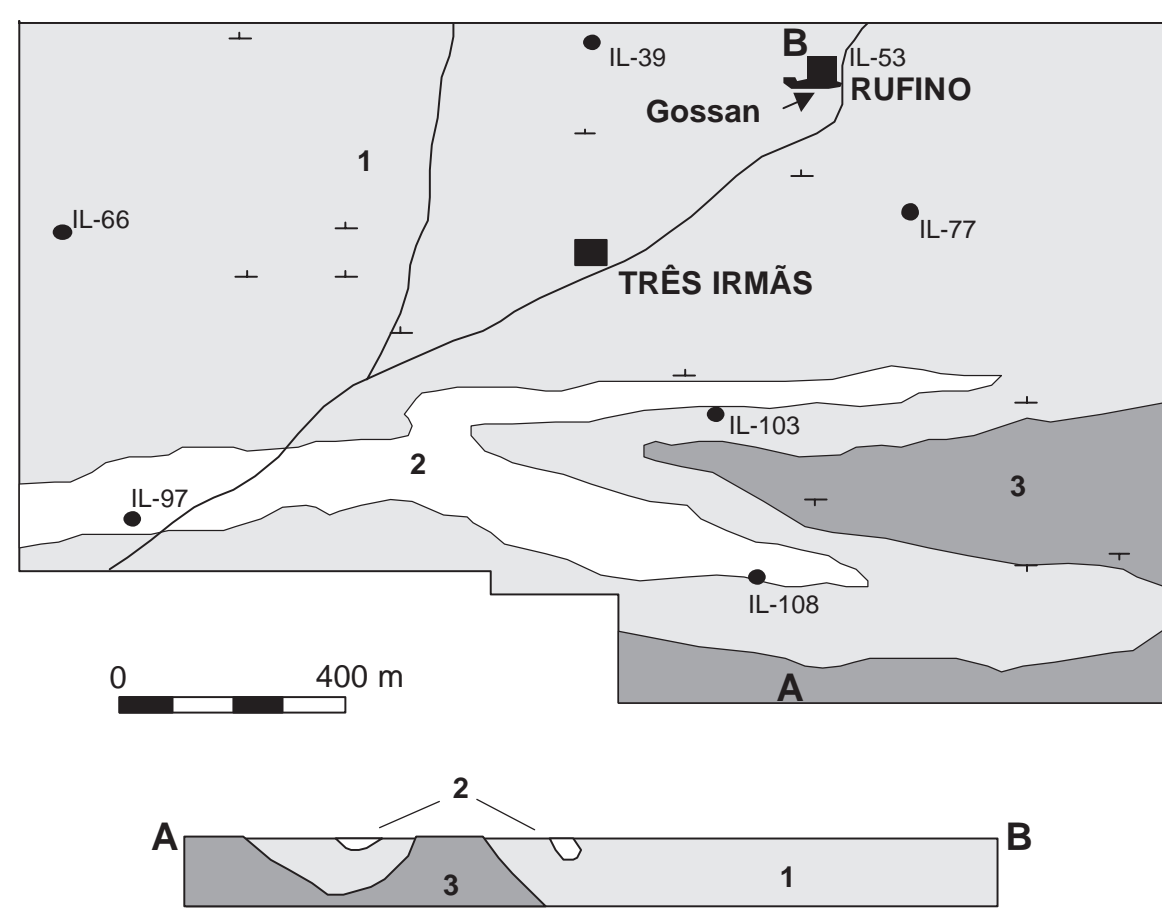

UNIT B1

(Subunits)

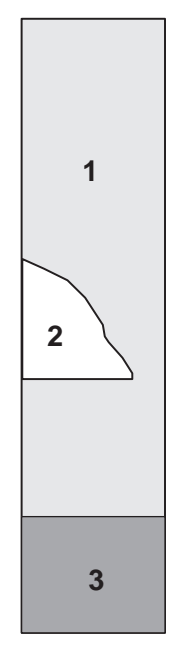

$(\mathrm{Zn}, \mathrm{Pb})$

$\left(\mathrm{P}_{2} \mathrm{O}_{5}\right)$

IL-77 Drill hole

Fig. 9. Geological map of the Três Irmãs/Rufino area, generalized after Monteiro (1989). (1) Subunit 1: Medium gray dolostone with tepees, evaporitic nodules, barite and $\mathrm{Fe}-\mathrm{Pb}-\mathrm{Zn}$ sulfides (uppermost part) current-cross bedding, disturbed laminae, local intraclasts and columnar stromatolites, phosphatic. (2) Subunit 2: Dark-gray calcilutite, peloidal calcarenite. (3) Subunit 3: Dark and light gray parallel-laminated dolomitic micrite. After Misi and Kyle (1994) and Kyle and Misi (1997). 


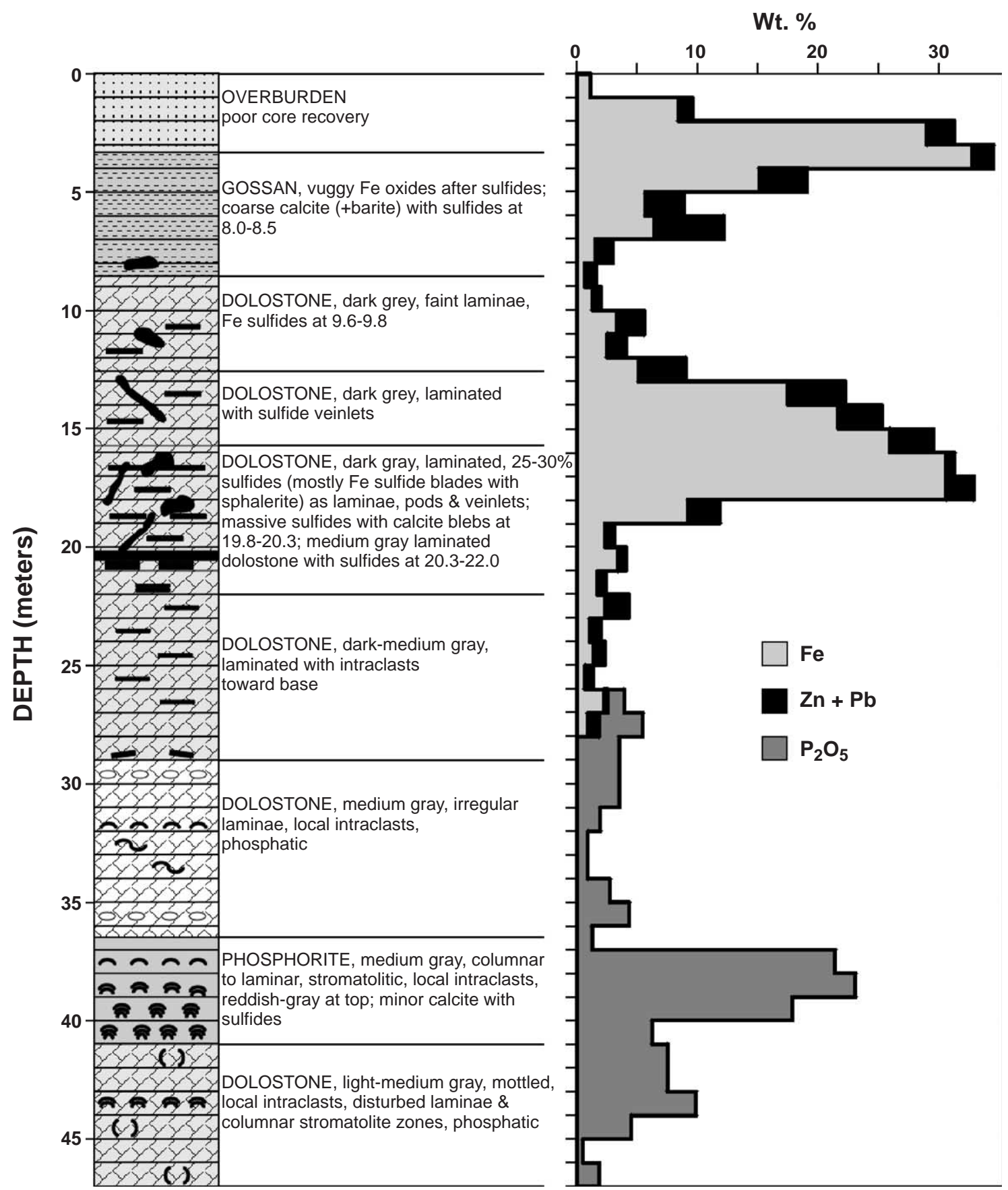

Fig. 10. Lithologic description and geochemical analysis of IL 53 core at Rufino or Três Irmãs area, Irecê deposit. Core intercept is within a 50 $\mathrm{m}$ thick tidal flat sequence of the Salitre Formation, where phosphate mineralization is at a lower stratigraphic position in relation to the sulfide ore. After Misi and Kyle (1994). 
preserve sedimentary structures indicative of shallow water evaporative formation, as shown by nodules of microquartz (fibrous, length slow), quartz pseudomorph from gypsum, teepee structures and laminar stromatolites (Misi et al., 1999).

During exploration in the Una-Utinga Basin, CPRM discovered several $\mathrm{Pb}-\mathrm{Zn}$ and barite deposits, and noticed prominent soil and stream sediment geochemical anomalies and gossans. $\mathrm{A}$ small $\mathrm{Pb}-$ $\mathrm{Zn}-(\mathrm{Ag})$ deposit in the Nova Redenção area (Fig. 1), with an estimated ore reserve of $2.5 \mathrm{Mt}$ at $6.3 \% \mathrm{~Pb}$, $0.5 \% \mathrm{Zn}, 33 \mathrm{ppm} \mathrm{Ag}$, represents the major deposit discovered in the southern part of the basin. The intimate relationship of the deposits with structures oriented approximately $\mathrm{N} 45 \mathrm{~W}$ was establishing by mapping and drilling (Fig. 12). Stratabound galena, sphalerite, pyrite, cerussite and anglesite are the major ore minerals and are associated with microquartz, megaquartz, hematite and barite. The ore forms massive lenses and dissemination in the dolarenites, cementing the matrix of oolitic and brecciated dolostones, forming nodules and remobilized veins. The close association between mineralization and $\mathrm{N} 45 \mathrm{~W}$ fractures is remarkable. Fractures can be followed for more than $10 \mathrm{~km}$ (Misi et al., 1999).

\subsection{São Francisco Valley (São Francisco Basin)}

Several small mineral deposits and prospects (Serra do Ramalho, Montalvânia, Januária-Itacarambí and others) distributed over a large area to the east of the São Francisco River (Figs. 1 and 2) have been described by Robertson (1963), Beurlen (1974), Cassedanne (1972), Miranda et al. (1976), Misi (1976, 1978) and Dardenne (1978). These authors and several others described the stratigraphic sequence in the São Francisco Basin. Misi and Veizer (1998), using chemostratigraphic data, demonstrated the possible correlation of Irecê and Serra do Ramalho sequences (Fig. 3). Martins (1999) suggested the existence of a sequence boundary at the top of the Sete Lagoas Formation at the dolomites with teepee structures (hosting the $\mathrm{Pb}-\mathrm{Zn}$ deposits and occurrences).

Misi (1978) described three types of mineralization in the Serra do Ramalho area: (i) disseminated galena and sphalerite in silicified dolomites; (ii) massive sulfides in the matrix of the dolostone with cm-scale syn-sedimentary breccias (very small occurrences); and (iii) veins and pods of minor remobilized galena associated with calcite and/or quartz with abundant fluorite.

According to Dardenne (1978) the sulfide deposits of the São Francisco Valley were deposited near the end of a regressive cycle (Fig. 13). Geologists from the Companhia Baiana de Pesquisa Mineral (CBPM) recently demonstrated the association of the sulfide occurrence at the Cocos area, near Montalvânia, with a N20-40W/70 ${ }^{\circ} \mathrm{SW}$ fault system.

Epigenetic fluorite deposits are very common in the São Francisco valley. Major deposits are associated with breccias related to paleokarst systems, below the dolomitic beds with teepee structures. The fluorite mineralization post-dates the sulfide formation.

\section{Lead isotopic constraints}

Lead isotopic investigation on the sulfides of the Vazante and Morro Agudo deposits started with the pioneering work of Amaral (1968) and Cassedanne and Lassère (1969). Further detailed studies were carried out by Iyer (1984) and Iyer et al. (1992). Lead isotopic investigations were also carried out on basement rocks and the sedimentary cover hosting the deposits (Barbosa, 1986; Marinho, 1991; Cordani et al., 1992; Silva, 1992; Babinski, 1993; Santos Pinto, 1996).

In this contribution, we present new $\mathrm{Pb}$ isotope data along with previously published analyses on sulfides from different deposits in the São Francisco Craton (Table 1). The implications of these data for the metallogenic evolution of the deposits are discussed and clues for future exploration are pointed out.

\subsection{Analytical methods}

The majority of the samples analyzed are from drill cores while the remaining samples are from underground mines or from trenches. $\mathrm{Pb}$ isotopic analyses were carried out on galena crystal aggregates from all deposits and, in addition, coexisting sphalerite and pyrite in the Irecê deposit were also analyzed. Samples from Morro Agudo, Vazante, 

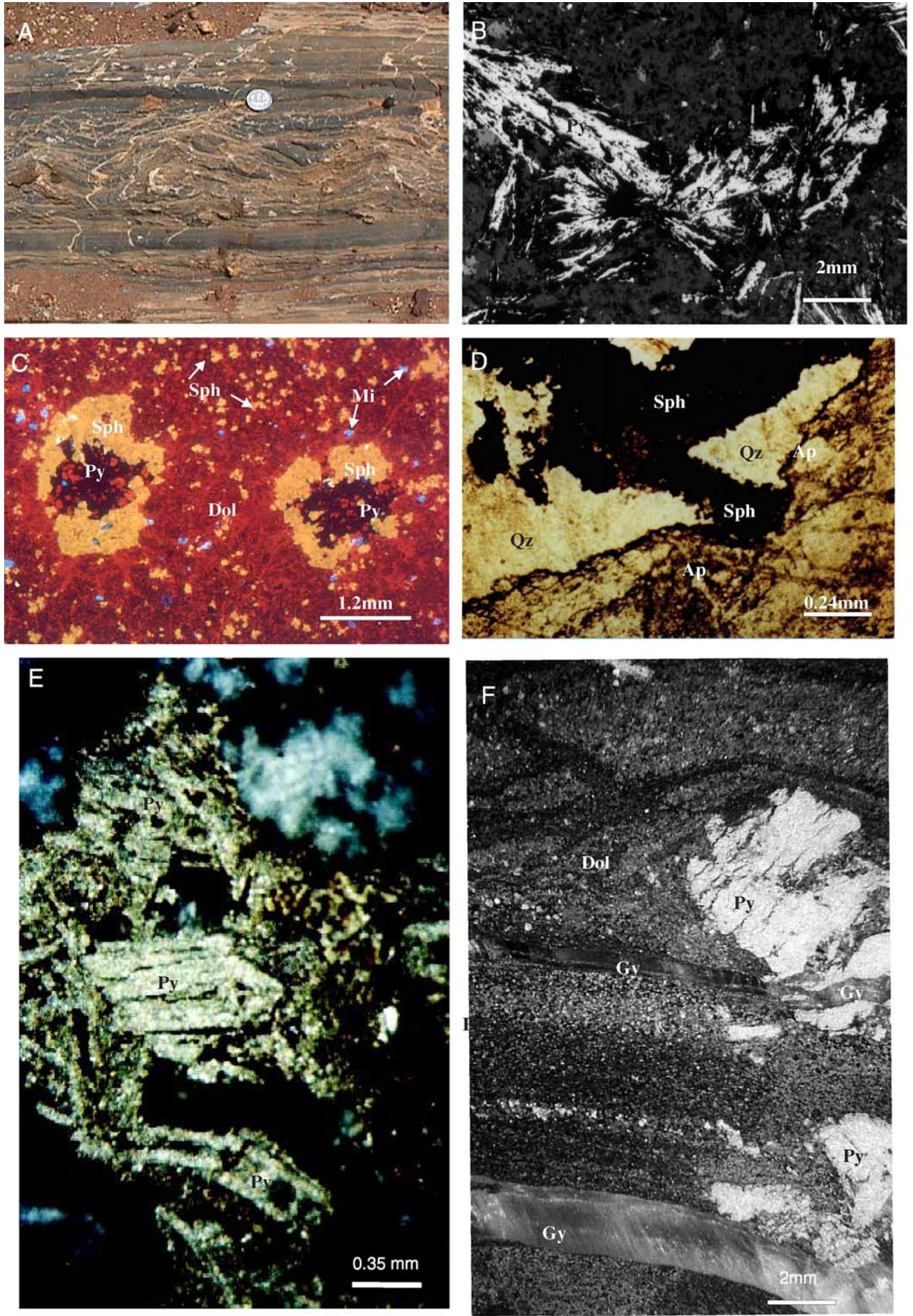
(a)

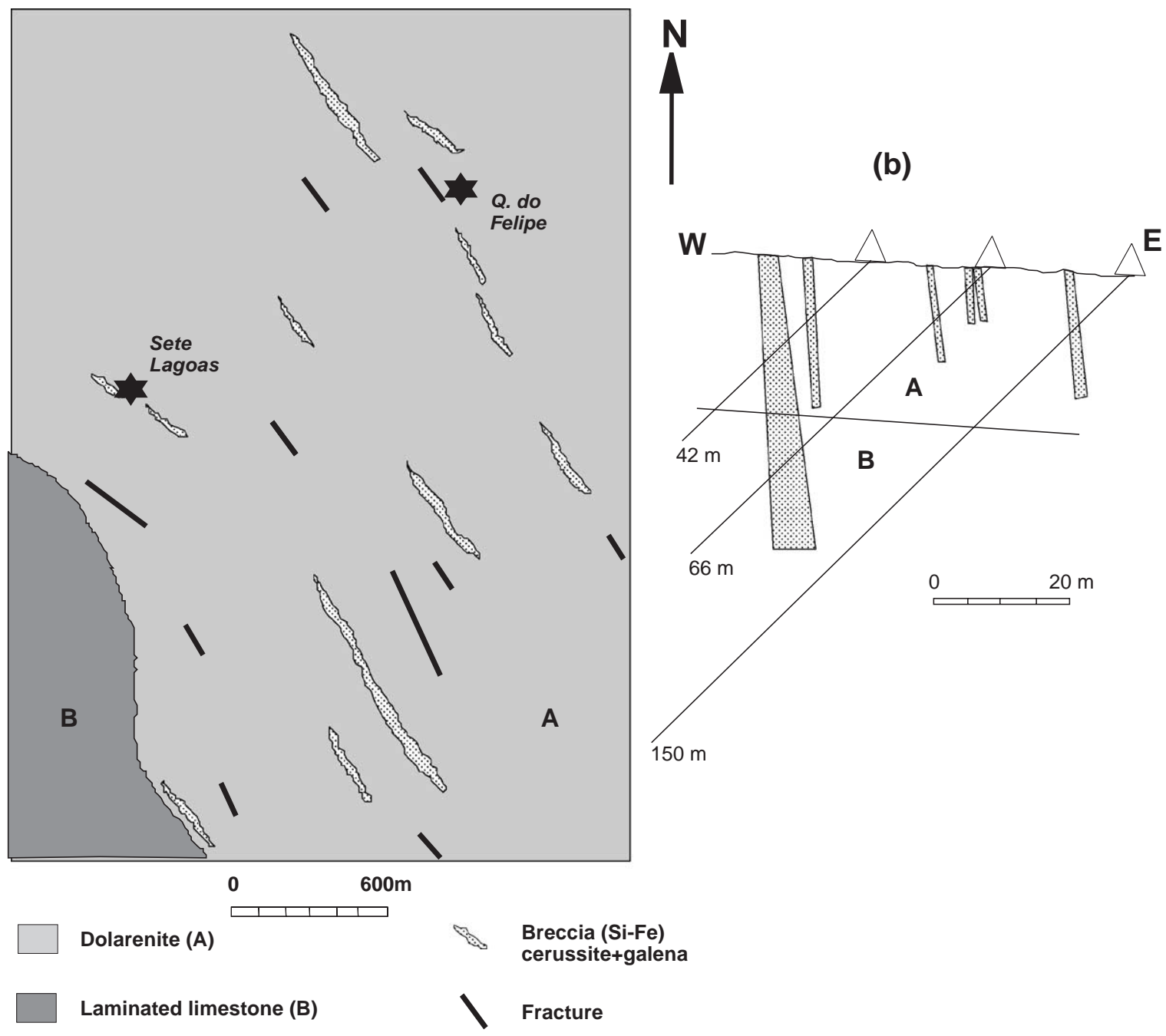

\section{$\widehat{P b}-Z n$ deposits}

Fig. 12. (a) Simplified geological map of Nova Redenção area, with the two main $\mathrm{Zn}-\mathrm{Pb}$ deposits closely associated with N45W fractures and aligned breccia zones. (b) Cross section at the Sete Lagoas deposit based on 3 drill holes. After Moraes Filho and Leal (1990).

Fig. 11. Macro- and microscopic features observed in the mineralized zone and in the host rock at the Irecê deposit, Irecê Basin. (A) Teepee structures in dolostone and limestone of Unit B1, upper part of Salitre Formation (Una Group), Irecê Basin. (B) Radial bladed pyrite aggregates, probably pseudomorphs after sulfate (gypsum). Reflected light photomicrography. (C) Complex nodules within dolostone (Dol) with an inner core of pyrite (Py) surrounded by coarse-crystalline sphalerite (Sph). Sphalerite also occurs as pore-filling crystals in dolostone. Microcline detrital minerals (Mi) in blue color. Cathodoluminescence photomicrograph from Kyle and Misi (1997). (D) Coarse crystalline sphalerite (Sph) within microquartz (Qz - length-slow quartz) in contact with carbonate fluorapatite (Ap) in dolostone. Probably a sulfate nodule replaced by microquartz and by sphalerite post-dating the apatite formation. Transmitted light photomicrography. (E) Bladed pyrite aggregates (Py), pseudomorphs after sulfates within dolostone (Dol). Note pyrite crystals with the typical twining forms of gypsum. Reflected light photomicrograph. (F) Pyrite nodule (?) within dolostone (Dol) with gypsum beds (Gy). Laminations are deformed probably by growth nodule. Photomicrograph with vertical illumination of a core sample, IL 53 drill hole (CBPM). 
(a)

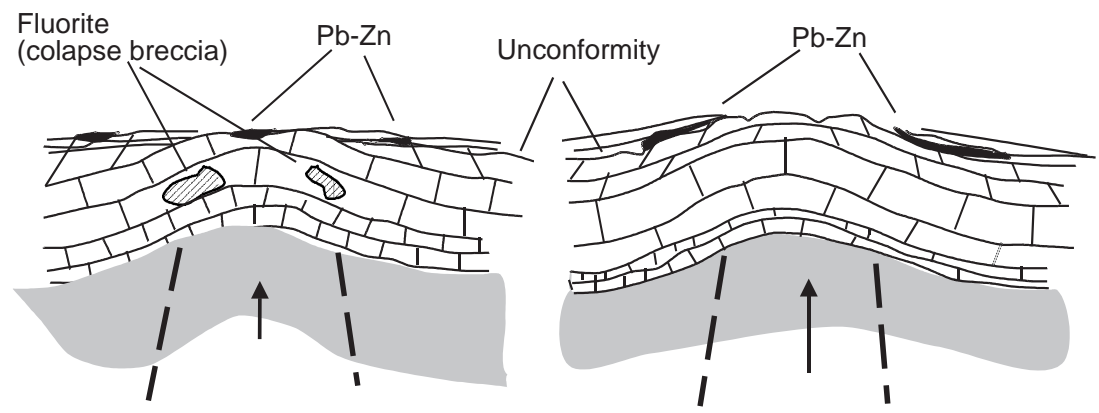

Fig. 13. Schematic cross sections at Campo Alegre and Mina Grande deposits, São Francisco Valley, according to Dardenne (1978): (a) Campo Alegre (Serra do Ramalho); (b) Mina Grande (Itacacambí).

Nova Redenção and Serra do Ramalho were analyzed at the Geochronology Center of the University of São Paulo, Brazil, using a Micromass VG 354 instrument. The data are reported with a precision and accuracy of $\pm 0.1 \%$. Sulfides from Irecê were analyzed at the Max Planck Institute, Mainz, Germany, using a MAT 261 mass spectrometer. The precision reported was $\pm 0.1 \%$. Samples from the deposits of the São Francisco Valley were analyzed by Iyer (1984) and Iyer et al. (1992) with a precision varying between $0.2 \%$ and $0.4 \%$. The analytical methods and procedures are reported in the referred papers.

\subsection{Results}

The isotopic data show that galena and other sulfides analyzed are in general highly enriched in radiogenic lead with ${ }^{206} \mathrm{~Pb} /{ }^{204} \mathrm{~Pb}$ as high as $25.41 \pm 0.5$ (Fig. 14) and the data points plot well above the plumbotectonic model lead isotope growth curve for an upper crustal source (Fig. 15). The enriched radiogenic $\mathrm{Pb}$ isotopic composition of the sulfides appears to have resulted from the highly radioactive nature of the crust in the region, where even the granulitic rocks are highly radioactive (Iyer et al., 1995). It is worth recalling that the senior authors are developing a craton specific $\mathrm{Pb}$ isotope evolution curve for the upper crust of the São Francisco Craton, using whole rock lead isotope data of samples spanning a period from the Archean to the Neoproterozoic.
The data points from Morro Agudo/Vazante and Nova Redenção (Fig. 15) plot very close to the position corresponding to the inferred age values for the host sedimentary rocks, while the data points for sulfides from Irecê and São Francisco Valley plot well above the plumbotectonic $\mathrm{Pb}$ evolution curves. The $\mathrm{Pb}$ isotope data show a linear distribution in the $\mathrm{Pb}-$ $\mathrm{Pb}$ isotope plot. Lead isotope data for individual deposits are discussed below.

\subsubsection{Irecê Basin}

The 12 analyzed samples comprise massive or disseminated and stratiform, sulfides (galena, sphalerite and pyrite) from two drill holes of the Rufino deposit and the three coarse galena samples are from quartz + calcite veins of the Morro do Gomes deposit, interpreted to be a remobilized mineralization. The data show two distinct groups. In the first group, ${ }^{206} \mathrm{~Pb} /{ }^{204} \mathrm{~Pb}$ ratios vary from 22.909 to 26.452 (average value $=25.699$ ) while the average ${ }^{207} \mathrm{~Pb} /{ }^{204} \mathrm{~Pb}$ and ${ }^{208} \mathrm{~Pb} /{ }^{204} \mathrm{~Pb}$ values are 16.797 and 42.839. In the second group, the isotopic ratios are homogeneous with ${ }^{206} \mathrm{~Pb} /{ }^{204} \mathrm{~Pb}$ ratios varying from 18.4703 to 18.4844 (average value of 18.475). The average ${ }^{207} \mathrm{~Pb} /{ }^{204} \mathrm{~Pb}$ and ${ }^{208} \mathrm{~Pb} /{ }^{204} \mathrm{~Pb}$ values for this group are 15.829 and 39.099, respectively. The highly enriched radiogenic $\mathrm{Pb}$ isotope values indicate the elevated $U$ and $T h$ values of the source rocks from which the lead was derived. The data points, when plotted in the ${ }^{207} \mathrm{~Pb} /{ }^{204} \mathrm{~Pb}$ vs. ${ }^{206} \mathrm{~Pb} /{ }^{204} \mathrm{~Pb}$ plot, show a linear relationship or a secondary isochron line $($ slope $=0.1328)$. 


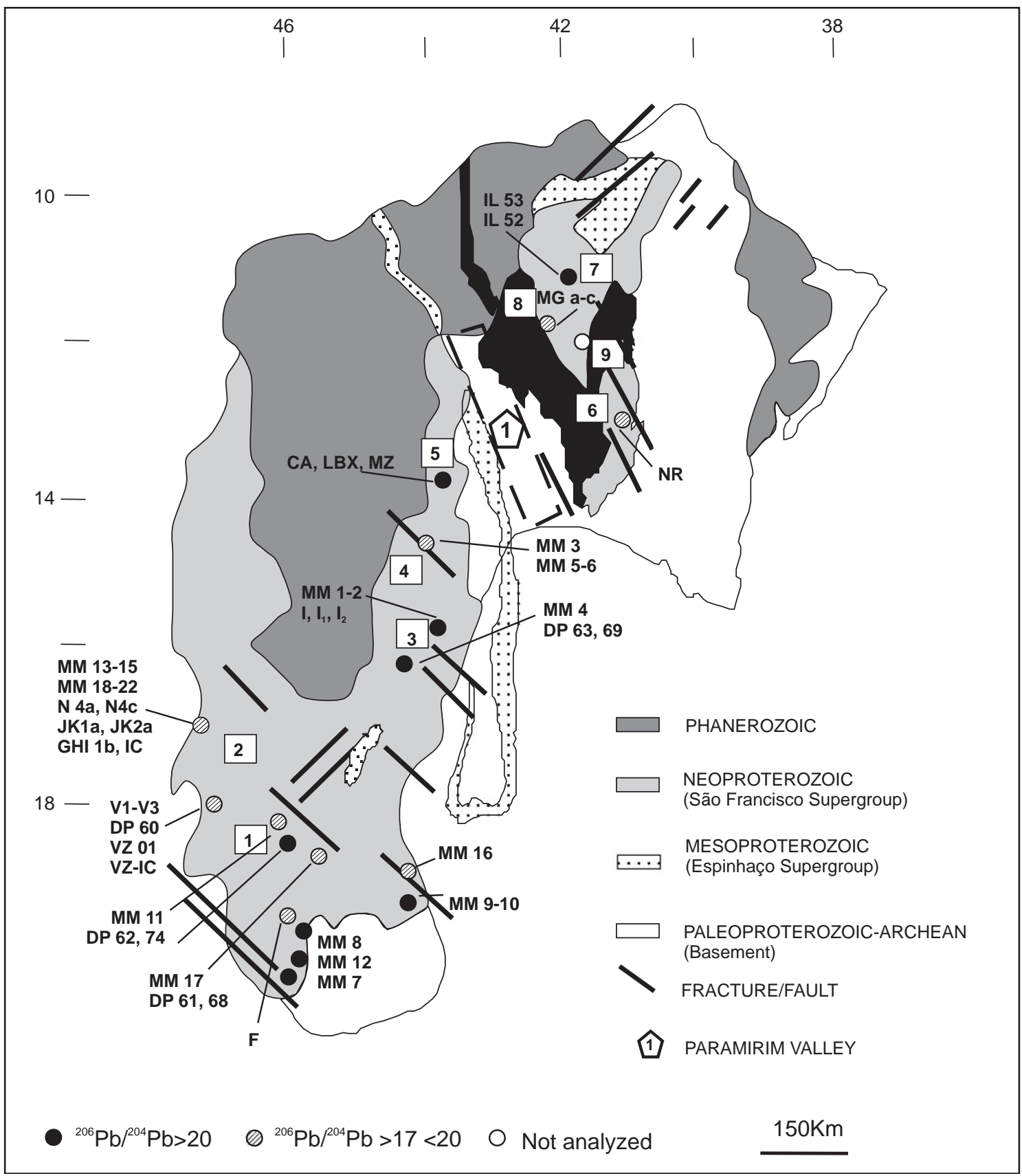

Fig. 14. Variation in ${ }^{206} \mathrm{~Pb} /{ }^{204} \mathrm{~Pb}$ for the Neoproterozoic $\mathrm{Zn}-\mathrm{Pb}$ deposits of the São Francisco Craton. See Table 3 for data and references and Fig. 1 for deposit names.

Since the sulfides studied are devoid of any radioactive mineral inclusions the isochron should represent a growth line for the time interval between the formation of the source rock $(T)$ and the mineralization $(t)$ when the $\mathrm{Pb}$ isotopic evolution ceased. This growth line is expressed in the following 
Table 1

$\mathrm{Pb}$ isotope data for the $\mathrm{Zn}-\mathrm{Pb}$ deposits studied

\begin{tabular}{|c|c|c|c|c|}
\hline & ${ }^{206} \mathrm{~Pb} /{ }^{204} \mathrm{~Pb}$ & ${ }^{207} \mathrm{~Pb} /{ }^{204} \mathrm{~Pb}$ & ${ }^{208} \mathrm{~Pb} /{ }^{204} \mathrm{~Pb}$ & Description \\
\hline \multicolumn{5}{|c|}{ Irecê (Misi, 1999) } \\
\hline IL 53-8.89c & 26.71 & 16.90 & 43.46 & Galena: massive, stratabound \\
\hline IL $5312.85 \mathrm{c}$ & 25.45 & 16.74 & 42.77 & Galena: massive, with barite \\
\hline IL 53-8.89a & 26.99 & 17.01 & 43.83 & Pyrite: massive, stratabound \\
\hline IL 5312.85a & 26.73 & 16.93 & 43.51 & Pyrite: blades with barite \\
\hline IL $5317.70 \mathrm{~b}$ & 26.73 & 16.93 & 43.54 & Sphalerite: fine grain., dissemin. \\
\hline IL $5317.70 \mathrm{a}$ & 26.78 & 16.92 & 43.51 & Pyrite: fine grain., dissemin. \\
\hline IL $5317.70 \mathrm{c}$ & 26.65 & 16.91 & 43.45 & Galena: fine grain., dissemin. \\
\hline IL $5317.50 \mathrm{a}$ & 24.87 & 16.68 & 42.18 & Pyrite: coarse grain., bladed \\
\hline IL $5317.50 \mathrm{~b}$ & 24.89 & 16.68 & 42.17 & Sphalerite: coarse grain. \\
\hline IL $5215.12 \mathrm{a}$ & 22.93 & 16.47 & 41.07 & Pyrite: bladed, with gypsum \\
\hline IL $5215.12 \mathrm{c}$ & 22.91 & 16.44 & 40.99 & Galena: fine grain., dissemin. \\
\hline IL $5315.87 \mathrm{a}$ & 26.75 & 16.95 & 43.58 & Pyrite: massive, stratabound \\
\hline $\mathrm{MGa}$ & 18.48 & 15.84 & 39.12 & Galena: coarse grain. with qz. and calcite \\
\hline MGb & 18.47 & 15.82 & 39.07 & Galena: coarse grain. with qz. \\
\hline MGc & 18.47 & 15.83 & 39.08 & Galena: coarse grain. with qz. \\
\hline \multicolumn{5}{|c|}{ Nova Redenção (Gomes, 1998; Misi, 1999) } \\
\hline NR AM 1 & 19.30 & 16.08 & 39.50 & Galena: coarse grain., Veins \\
\hline NR AM 8 & 18.59 & 15.89 & 37.97 & Galena: fine grain., dissemin. \\
\hline NR $14-25,45$ & 19.30 & 16.06 & 39.44 & Galena: massive, pods \\
\hline NR $12-25,5$ & 19.34 & 16.08 & 39.55 & Galena: fine grain., dissemin. \\
\hline NR $12-32,5$ & 19.47 & 16.20 & 39.92 & Galena: cementing ooid structures \\
\hline NR $12-25,45 b$ & 19.67 & 16.34 & 40.13 & Galena: dissemin., with qz. \\
\hline NR 12-28,6a & 19.50 & 16.26 & 40.11 & Galena: cementing ooid structures \\
\hline NR $25-0,6$ & 19.24 & 16.02 & 39.28 & Galena: massive, pods \\
\hline
\end{tabular}

Vale do São Francisco (Iyer et al., 1992; Amaral, 1968; Cassedanne and Lassère, 1969)

\begin{tabular}{lllll} 
MM 1 & 19.72 & 15.79 & 38.55 & Galena \\
MM 2 & 20.24 & 15.94 & 40.29 & Galena \\
MM 3 & 20.02 & 15.93 & 39.85 & Galena \\
MM 4 & 19.83 & 15.85 & 39.05 & Galena \\
MM 5 & 18.92 & 15.83 & 38.64 & Galena \\
MM 6 & 18.94 & 15.80 & 38.48 & Galena \\
MM 7 & 24.87 & 16.29 & 46.05 & Galena \\
MM 8 & 36.43 & 18.21 & 45.63 & Galena \\
MM 9 & 20.52 & 15.48 & 43.93 & Galena \\
MM 10 & 19.95 & 15.29 & 37.21 & Galena \\
MM 11 & 18.92 & 17.75 & 37.95 & Galena \\
MM 12 & 32.12 & 15.62 & 44.93 & Galena \\
MM 16 & 18.91 & 15.82 & 37.89 & Galena \\
MM 17 & 19.13 & 15.85 & 38.54 & Galena \\
T & 19.60 & 16.10 & 38.87 & Galena \\
I & 20.60 & 16.10 & 40.90 & Galena \\
$I_{1}$ & 20.30 & 16.36 & 40.90 & Galena \\
$I_{2}$ & 20.54 & 15.90 & 41.56 & Galena \\
F & 19.06 & 15.52 & 38.99 & Galena \\
DP 61 & 19.02 & 15.78 & 37.63 & Galena \\
DP 68 & 19.34 & 16.00 & 38.34 & Galena \\
DP 63 & 19.95 & 16.10 & 39.53 & Galena \\
DP 69 & 19.96 & 15.86 & 39.45 & Galena \\
DP 62 & 19.86 & 15.96 & 38.98 & Galena \\
DP 74 & 19.92 & & 39.21 & Galena \\
\hline & & &
\end{tabular}


Table 1 (continued)

\begin{tabular}{|c|c|c|c|c|}
\hline & ${ }^{206} \mathrm{~Pb} /{ }^{204} \mathrm{~Pb}$ & ${ }^{207} \mathrm{~Pb} /{ }^{204} \mathrm{~Pb}$ & ${ }^{208} \mathrm{~Pb} /{ }^{204} \mathrm{~Pb}$ & Description \\
\hline \multicolumn{5}{|c|}{ Serra do Ramalho (Gomes, Misi and Babinski, unpublished) } \\
\hline CA-4 & 23.44 & 16.33 & 41.83 & Galena disseminated in carbonate rock \\
\hline CA-9 & 23.40 & 16.37 & 42.07 & Galena disseminated in carbonate rock \\
\hline CA-10a & 23.35 & 16.31 & 41.89 & Galena disseminated in fluorite \\
\hline CA-10b & 23.43 & 16.38 & 42.05 & Galena disseminated in carbonate rock \\
\hline CA-12 & 23.22 & 16.31 & 41.90 & Galena disseminated in carbonate rock \\
\hline LBX-1 & 30.73 & 17.58 & 49.75 & Galena disseminated in fluorite \\
\hline LBX-3 & 30.78 & 17.57 & 49.73 & Galena (coarse grain.) disseminated \\
\hline LBX-4 & 32.76 & 17.92 & 53.54 & Galena disseminated in carbonate rock \\
\hline LBX-5 & 30.23 & 17.58 & 49.53 & Galena coarse grained \\
\hline LBX-8 & 30.22 & 17.45 & 49.27 & Galena disseminated in fluorite \\
\hline MZ-3 & 18.68 & 15.78 & 38.59 & Nodular galena dissemin. in dolarenite \\
\hline
\end{tabular}

Morro Agudo/Vazante (Iyer et al., 1992; Amaral, 1968; Cassedanne and Lassère, 1969)

$\begin{array}{lllll}\text { MM 13 } & 17.69 & 15.57 & 36.89 & \text { Galena } \\ \text { MM 14 } & 17.79 & 15.60 & 36.98 & \text { Galena } \\ \text { MM 15 } & 17.91 & 15.81 & 37.67 & \text { Galena } \\ \text { MM 18 } & 17.78 & 15.71 & 37.24 & \text { Galena } \\ \text { MM 19 } & 17.76 & 15.71 & 37.25 & \text { Galena } \\ \text { MM 20 } & 15.69 & 37.15 & \text { Galena } \\ \text { MM 21 } & 17.91 & 15.71 & 37.25 & \text { Galena } \\ \text { MM 22 } & 17.79 & 15.71 & 37.24 & \text { Galena } \\ \text { V1 } & 17.79 & 15.62 & 37.06 & \text { Galena } \\ \text { V2 } & 17.68 & 15.56 & 37.06 & \text { Galena } \\ \text { V3 } & 17.64 & 15.81 & 37.39 & \text { Galena } \\ \text { DP60 } & 17.85 & 15.59 & 36.90 & \text { Galena }\end{array}$

(Misi, 1999)

$\begin{array}{lllll}\text { MA N 4a } & 17.79 & 15.79 & 37.37 & \text { Galena } \\ \text { MA N 4c } & 17.85 & 15.77 & 37.40 & \text { Galena } \\ \text { JK 1a } & 18.00 & 15.94 & 37.86 & \text { Galena } \\ \text { JK 2a } & 17.87 & 15.77 & 37.40 & \text { Galena } \\ \text { GHI 1b } & 17.85 & 15.79 & 37.43 & \text { Galena } \\ \text { VZ 01 } & 17.70 & 15.65 & 37.07 & \text { Galena } \\ & & & & \\ \text { (Cunha et al., 2001) } & & & 37.47 & \text { Galena } \\ \text { IC-50 (GHI) } & 17.81 & 15.76 & 37.28 & \text { Galena } \\ \text { IC-16 (JK) } & 17.76 & 15.70 & 37.00 & \text { Galena } \\ \text { IC-4 (JK) } & 17.68 & 15.61 & 37.51 & \text { Galena } \\ \text { IC-47 (M) } & 17.82 & 15.77 & 37.56 & \text { Galena } \\ \text { IC-48 (M) } & 17.84 & 15.79 & 37.20 & \text { Galena } \\ \text { IC-51 (GHI) } & 17.75 & 15.68 & 37.04 & \text { Galena } \\ \text { IC-46 (N) } & 17.65 & 15.64 & 37.14 & \text { Galena } \\ \text { IC-44 (GHI) } & 17.73 & 15.66 & 37.05 & \text { Galena } \\ \text { IC-40 (N) } & 17.66 & 15.64 & 37.12 & \text { Galena } \\ \text { IC-33 (JK) } & 17.70 & 15.65 & 37.17 & \text { Galena } \\ \text { VZ-IC-F1106 } & 17.73 & 15.67 & 37.30 & \text { Galena } \\ \text { VZ-IC-F1136 } & 17.76 & 15.71 & 37.18 & \text { Galena } \\ \text { VZ-IC-F797 } & 17.72 & 15.67 & 37.47 & \\ \text { VZ-IC-F104 } & 17.74 & 15.69 & & \end{array}$




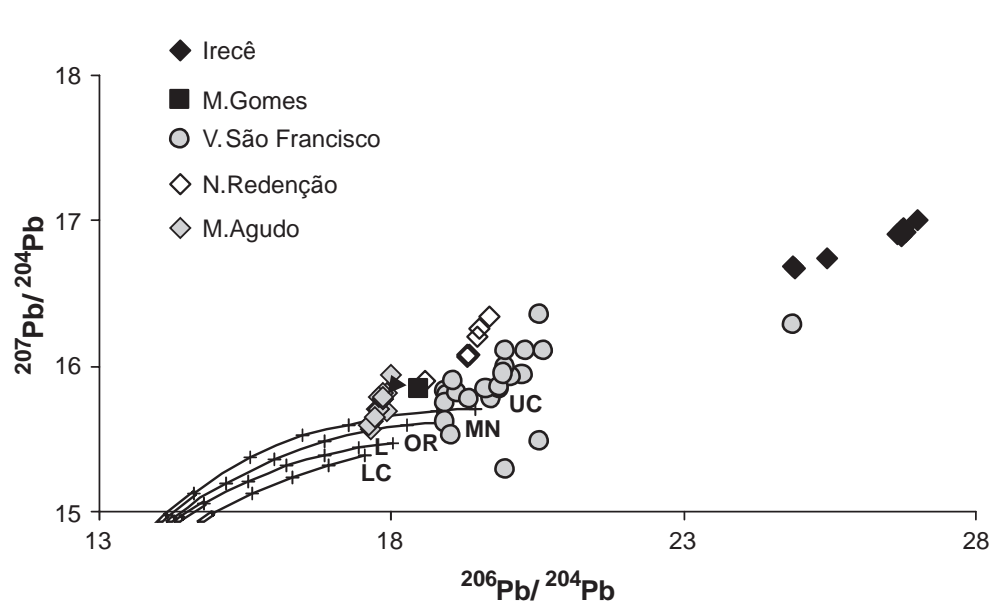

Fig. 15. Lead isotope composition of sulfides from Proterozoic $\mathrm{Pb}-\mathrm{Zn}$ deposits of the São Francisco Craton. Evolution curves according to the plumbotectonic model of Zartman and Doe (1981). The upper curve corresponds to the evolution in the upper crust (UC), followed by the mantle (MN), orogen (OR) and lower crust (LC).

equation (Holmes-Houtermans model), where $T=$ age of the source rock, $t=$ age of the mineralization, $\lambda=$ constant of decay of ${ }^{238} \mathrm{U}\left(0.155125 \times 10^{-9}\right)$ and $\lambda^{\prime}=$ constant of decay of ${ }^{235} \mathrm{U}\left(0.98485 \times 10^{-9}\right)$ :

$$
\begin{aligned}
& \frac{\left({ }^{207} \mathrm{~Pb} /{ }^{204} \mathrm{~Pb}\right)_{t}-\left({ }^{207} \mathrm{~Pb} /{ }^{204} \mathrm{~Pb}\right)_{T}}{\left({ }^{206} \mathrm{~Pb} /{ }^{204} \mathrm{~Pb}\right)_{t}-\left({ }^{206} \mathrm{~Pb} /{ }^{204} \mathrm{~Pb}\right)_{T}} \\
& =\frac{1}{137.88} \frac{\left\{\mathrm{e}^{\left(\lambda^{\prime} T\right)}-\mathrm{e}^{\left(\lambda^{\prime} t\right)}\right\}}{\left\{\mathrm{e}^{(\lambda T)}-\mathrm{e}^{(\lambda t)}\right\}}=\text { slope }
\end{aligned}
$$

Assuming a possible age of mineralization $(t)$ from geological and other criteria, the probable age $(T)$ of the source rock could be estimated. For Irecê, a mineralization age of $0.65 \mathrm{Ga}(t)$ would yield an age $(T)$ between 1.7 and $1.8 \mathrm{Ga}$. for the source. Such an age corresponds to the felsic to intermediate magmatic episode involving many granitic intrusions closely related to the widespread Espinhaço event in the São Francisco Craton.

A comparison of the secondary isochron for the sulfides studied here with the $\mathrm{Pb}-\mathrm{Pb}$ isochron line of the Lagoa Real granite complex whole rocks $(1.705 \pm 0.1 \mathrm{Ga}$; Iyer et al., 1999) indicates a remarkable similarity (Fig. 16). These granites of the Lagoa Real Complex are located in the Paramirim valley and are related to anorogenic magmatic event during the Espinhaço rifting. The granites have relatively high $\mathrm{U}$ and Th concentrations ( $\mathrm{U}: 4$ to 20 ppm; Th: 15 to 76 ppm; Maruéjol et al., 1987).

\subsubsection{Nova Redenção (Una-Utinga Basin)}

The $\mathrm{Pb}$ isotopic data for the samples analyzed show limited variation (except for a fine grained sample disseminated in dolarenite) and the data plot well above the Plumbotectonic $\mathrm{Pb}$ isotope evolution curve for an upper crustal source (Fig. 15). The model ages calculated for individual samples using the twostage model of Zartman and Doe (1981) range from 400 to $600 \mathrm{Ma}$.

The highly radiogenic $\mathrm{Pb}$ isotope character of the sulfides is probably the result of a highly radioactive source that supplied the metals to the sedimentary basin. The limited spread in the $\mathrm{Pb}$ isotope data does not permit the calculation of the age of the source rocks as was done for Irecê sulfides.

\subsubsection{São Francisco Valley}

The $\mathrm{Pb}$ isotope data of sulfides from the São Francisco Valley (Table 1) are from Iyer (1984), Iyer et al. (1992) and Gomes et al. (unpublished data). The majority of galena samples analyzed yielded highly enriched radiogenic values. The ${ }^{206} \mathrm{~Pb} /{ }^{204} \mathrm{~Pb}$ ratio for the 36 samples ranges from 18.92 to 36.43 (Table 1). When plotted in the lead evolution diagram of Zartman and Doe (1981), the data fall above the upper-crustal model source, except for 4 samples (Fig. 15). 


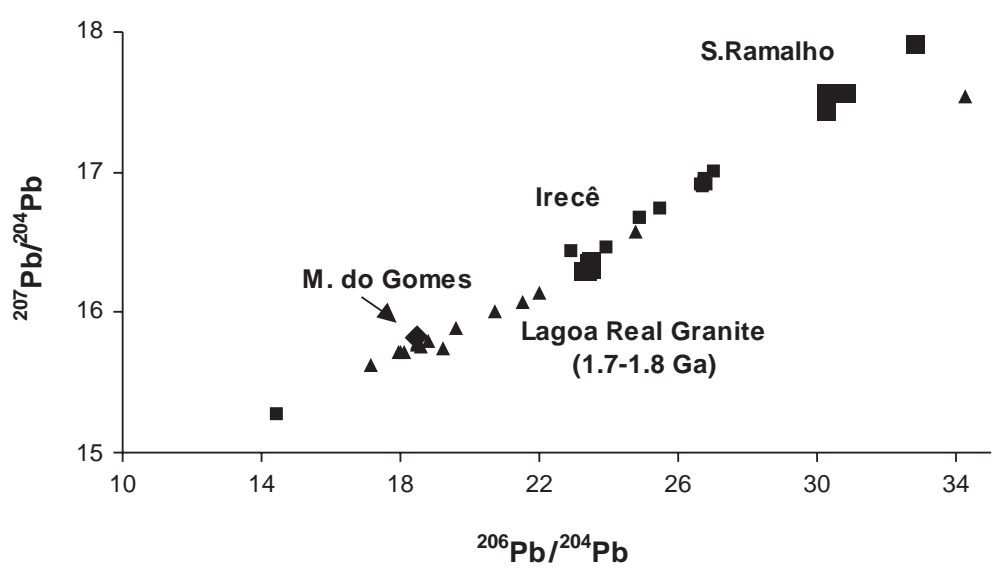

Fig. 16. Lead isotope plot of ${ }^{206} \mathrm{~Pb} /{ }^{204} \mathrm{~Pb}$ vs. ${ }^{207} \mathrm{~Pb} /{ }^{204} \mathrm{~Pb}$ for whole rock samples from Lagoa Real Granite, Paramirim Valley (closed triangles) and for galena and other sulfides from Serra do Ramalho, Irecê, Morro do Gomes and Nova Redenção deposits. See Table 1 for the data and references. Data from Lagoa Real Granite are from Iyer et al. (1999).

\subsubsection{Morro Agudo and Vazante}

The earliest lead isotopic analyses on Morro Agudo and Vazante sulfides were performed by Amaral (1968) and Cassedanne and Lassère (1969). Additional studies by Iyer (1984) and Iyer et al. (1992) showed a linear distribution (isochron) of the $\mathrm{Pb}$ isotopic data in the evolution diagram of Cumming and Richards (1975). The isochron cuts the $\mathrm{Pb}$ isotope evolution curve at two points, corresponding to ages of 650 and $1800 \mathrm{Ma}$. These dates were interpreted to mark the remobilization and deposition of the sulfides (650 Ma) and the age of the basement source rocks (1800 Ma). Galena samples from the Morro Agudo/ Vazante area are the least radiogenic among sulfides of equivalent age in the São Francisco Craton. The data show a zoning in the $\mathrm{Pb}$ isotope ratios with the values becoming more radiogenic away from the Morro Agudo/Vazante area, to the east. According to Iyer et al. (1992) such zoning represents either the incomplete mixing of a solution containing common lead with a solution containing varying proportions of radiogenic lead or mixing of solutions containing radiogenic lead with varying proportions of common lead. Over $200 \mathrm{~km}$ of zoning makes it necessary to invoke multiple flow involving solutions of different strength interacting with basement rocks over different intervals of time and extracting the metals (Iyer, 1984; Iyer et al., 1992).

Freitas Silva and Dardenne (1997) and Dardenne and Freitas-Silva (1998) presented $\mathrm{Pb}$ isotope data for
12 galena samples from the Morro Agudo mine and placed the samples into two groups, each formed during distinct but different events. The two groups are: (1) "primary" galena with a model age of 1050 $\mathrm{Ma}$; and (2) "remobilized" galenas of age 750 to 650 Ma. The authors provided the distribution of the data in a $\mathrm{Pb}$ evolution curve without providing further details.

In the present contribution, we present 16 additional galena analyses from different orebodies of the Morro Agudo mine (number of samples analyzed is given in the brackets): N (4), JKL (5), GHI (4) and M (2) along with 5 samples from Vazante. The $\mathrm{Pb}$ isotopic composition of these samples is homogeneous and reinforces the interpretation of Iyer et al. (1992).

The $\mathrm{Pb}$ isotopic investigation in Morro Agudo and Vazante has important implications for mineral exploration. Major orebodies present homogeneous and lowest radiogenic isotopic compositions and the isotopic signature could be used to discriminate between economic and minor deposits of lesser value (Gulson, 1986).

\subsection{Summary}

The preliminary conclusions related to the $\mathrm{Pb}$ isotopic data are that the metals for most deposits appear to have been derived from radioactively enriched basement rocks. The factors responsible 
for the variation in the $\mathrm{Pb}$ isotopic ratios are: (a) diverse basement source rocks containing different abundance of $\mathrm{U}$ and $\mathrm{Th}$, (b) varying reactivity (ionic strength, $\mathrm{pH}$, etc.) of the hydrothermal solutions attacking these rocks and (c) different lengths of time or periods of interaction of hydrothermal solution and the source rocks. The enriched $\mathrm{Pb}$ isotopic composition of the sulfides and the highly radioactive nature of the upper and middle to lower crust of the São Francisco Craton warrants the development of a Craton specific lead isotope evolution curve in this region. The age values calculated for the source rocks in the Irecê deposits from secondary isochrons correspond to the age values recorded for highly radioactive basement rocks. The ore forming episode dated by $\mathrm{Pb}$ isotopic method is associated with an important extensional event that took place during the evolution of the Neoproterozoic basins in the São Francisco Craton.

\section{Sulfur isotopic constraints}

Sulfide and barite samples from the deposits of Irecê, Nova Redenção, São Francisco Valley, Morro Agudo, and Vazante were analyzed for sulfur isotopes (Table 2, Figs. 17 and 18). The samples were selected after a detailed petrographic study and separated in the laboratory by hand picking under a binocular microscope. The majority of analyses were carried out at the Stable Isotope Laboratory of the University of Calgary, following procedures described by Iyer et al. (1992). The precision of the analyses is $\pm 0.2 \%$. Analyses of samples from the Irecê deposits were undertaken in laboratories of the United States Geological Survey (USGS), Reston, Virginia, with a precision of $\pm 0.2 \%$, and at the Coastal Science Laboratories, Inc., Austin, Texas, with a precision of $\pm 0.4 \%$ o. The analytical procedure followed at the USGS was described by Kyle and Misi (1997). The results of the 106 sulfide samples and 30 barite samples analyzed on the different deposits are shown in Table 2 and are discussed below.

\subsection{Irecê}

Sulfur isotope data for twenty sulfides (pyrite, galena, sphalerite, jordanite and a nodule of pyr- ite + galena + sphalerite), which were mainly from drill core samples, along with coexisting barite and gypsum samples from the deposits of Rufino or Três Irmãs, are presented in Table 2. The sulfates are enriched in ${ }^{34} \mathrm{~S}\left(\delta^{34} \mathrm{~S}=+25.2 \%\right.$ o to $+32.8 \%$; average $=+28.9 \% \circ \pm 2.9 \% \circ \mathrm{CDT})$, and these values coincide with the sulfur isotope composition of marine basins at the end of the Proterozoic $(+18 \%$ o to $+34 \%$ o CDT; Claypool et al., 1980). The primary sulfides from Irecê have $\delta^{34} \mathrm{~S}$ values in the range of $+19.1 \%$ o to $+25.1 \%$ o (mean $+21.6 \pm 1.3 \%$ CDT). The small sulfur isotopic fractionation between sulfides and sulfates $(\sim 7 \%$ o $)$ suggests that these sulfides were formed by thermochemical reduction of sulfates. The presence of organic matter in the carbonates hosting the ore deposits could be the major factor inducing the thermochemical reduction process (Misi and Kyle, 1994; Kyle and Misi, 1997).

\subsection{Nova Redenção}

The sulfur isotopic data of 13 galena, 3 sphalerite, and 3 pyrite samples along with 4 barite samples from the enclosing dolarenites in this region are presented in Table 2 and shown in Fig. 17. Isotopic data of two cogenetic pairs of galena-sphalerite, apparently in isotopic equilibrium, have been used for geothermometric calculation. Barites yielded high positive $\delta^{34} \mathrm{~S}$ values $(+33.6 \%$ o to $+41 \%$ o CDT $)$, higher than those observed for the sea water sulfates at the end of the Proterozoic (Claypool et al., 1980) and could be the result of barite growth in a more restricted local basin. The variation in $\delta^{34} \mathrm{~S}$ values of sulfides is large $(0 \%$ o to $+18.6 \%$ o CDT; mean $+13.8 \%$ o $)$ with no difference for coexisting mineral phases. The large difference in the $\delta^{34} \mathrm{~S}$ values between sulfates and sulfides (up to $23 \%$ ) may be interpreted as related to sulfide formation by bacterial reduction of sulfates. However the temperatures calculated using the equation of Ohmoto and Rye (1979) for cogenetic galena-sphalerite pairs are high $\left(150\right.$ to $200{ }^{\circ} \mathrm{C}$, $\Delta^{34} \mathrm{~S}_{\mathrm{sph}-\mathrm{gal}}=4.0$ and 3.3 ) and thus may not be attributed to a bacterial reduction process.

\subsection{São Francisco Valley}

The isotopic data obtained for 10 galena samples from this region show $\delta^{34} \mathrm{~S}$ values in the range 


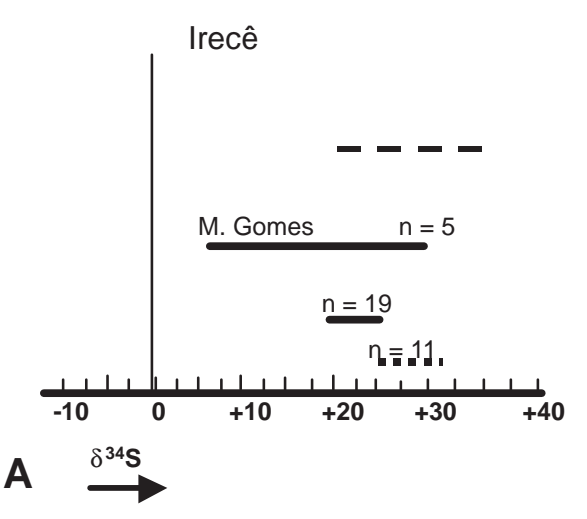

Vale do S. Francisco

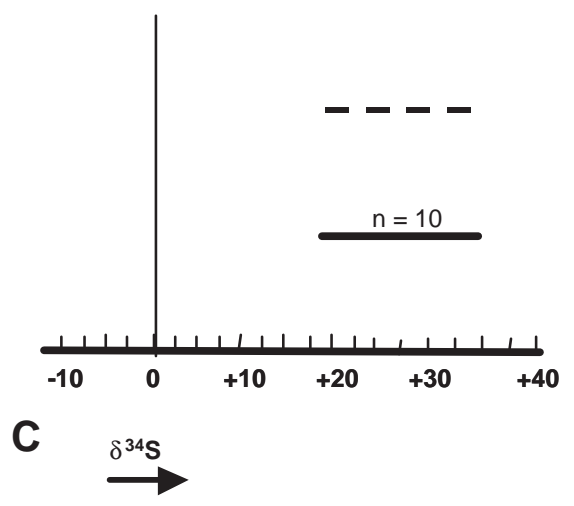

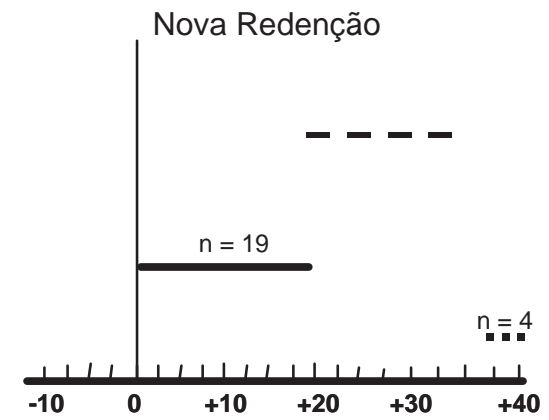

B $\stackrel{\delta^{345}}{\rightarrow}$

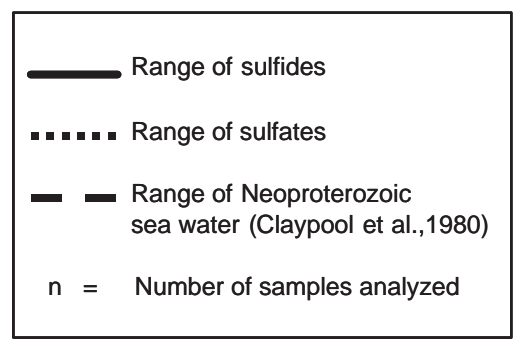

Fig. 17. Sulfur isotopic data for sulfides and sulfates from the zinc-lead deposits of the Neoproterozoic basins of the São Francisco Craton. See Table 2 for complete $\delta^{34} \mathrm{~S}$ data.

$+18 \%$ o to $+35 \%$ CDT (mean +25.3$)$ with $80 \%$ of the data falling in the restricted range of $+23 \%$ to $+27 \%$ o (Iyer et al., 1992). Lack of data on sulfates from this region does not permit any interpretation on the mode of sulfide formation.

\subsection{Morro Agudo}

There is a clear trend in the $\delta^{34} \mathrm{~S}$ values for the sulfides with highly enriched values in the stratigraphically lowermost breccia-type GHI body to less enriched values in the overlying oolitic stratabound JKL, and moderately to slightly depleted for the stratiform $\mathrm{N}$ orebody. Geothermometric calculations using the sulfur isotope data of cogenetic sphalerite-galena pair show increasing temperature values stratigraphically downward from $\mathrm{N}\left(100{ }^{\circ} \mathrm{C}\right)$, JKL $\left(150{ }^{\circ} \mathrm{C}\right)$ to GHL $\left(250{ }^{\circ} \mathrm{C}\right)$ orebody types (Fig. 18). Such a trend supports the hypothesis of a feeder zone associated with the fault. The sulfur isotope data for the barite samples $(+23 \%$ o to $+29 \%$ ) suggest their derivation from Neoproterozoic seawater.

\subsection{Vazante}

Sulfur isotope data are limited in the Vazante deposit (Table 2). The isotopic ratios for sphalerite and galena are in the range $+11.8 \%$ o to $+16.4 \%$ o (average of $+14.3 \%$ o CDT, $n=9$ ). The application of the isotopic geothermometric equation of Ohmoto and Rye (1979) for a cogenetic sphalerite-galena pair yielded a crystallization temperature of $\sim 270$ ${ }^{\circ} \mathrm{C}$. Although the sulfur isotope composition of these sulfides are less enriched compared to those from Morro Agudo, the values obtained in Vazante are compatible with the derivation of sulfur from a Proterozoic seawater sulfate source. Monteiro et al. 
Table 2

$\mathrm{S}$ isotope data $\left(\delta^{34} \mathrm{~S}\right)$ of sulfides and sulfates for the $\mathrm{Zn}-\mathrm{Pb}$ deposits studied

\begin{tabular}{|c|c|c|c|}
\hline & Mineral & Description & $\delta^{34} \mathrm{~S}$ \\
\hline \multicolumn{4}{|l|}{ Irecê } \\
\hline ML TR 00 & Barite & clear, massive, stratiform & 32.78 \\
\hline ML TR 02 & Barite & clear, massive, stratiform & 32.80 \\
\hline ML TR 10 & Barite & clear, massive, stratiform & 29.05 \\
\hline IR ML 1b & Barite & clear, massive, stratiform & 31.90 \\
\hline ML-a & Barite & white and brown, massive & 30.90 \\
\hline IR AM 21c & Barite & white, nodular & 29.40 \\
\hline IL $53-8.40 \mathrm{a}$ & Barite & white, nodular, with pyrite & 25.30 \\
\hline IL $53-8.40 \mathrm{~b}$ & Barite & dark gray, nodular, with pyrite & 25.90 \\
\hline IL 53-11.25a & Barite & white, veins with $\mathrm{qz}$ and calcite & 29.60 \\
\hline IL $53-12.85$ & Barite & white, nodular, with pyrite & 25.20 \\
\hline IL 53-31.42 & Barite & nodular, with qz microcrist. & 31.40 \\
\hline IL $3516.78 b$ & Gypsum & stratiform + veins with pyrite & 26.40 \\
\hline IL $5211.67 \mathrm{c}$ & Gypsum & veins with pyrite & 25.80 \\
\hline IR MG 1a & Galena & coarse crystal., within qz. vein & 32.21 \\
\hline IR MG 1b & Galena & lenses with $\mathrm{qz}+$ calc. & 25.95 \\
\hline IR MG 2 & Galena & lenses with $\mathrm{qz}+$ calc. & 28.64 \\
\hline $8-134$ & Galena & coarse crystal., with qz. + calc. & 12.30 \\
\hline IR BE 1 & Galena & gal $(70 \%)+$ sph. in qz. vein & 7.10 \\
\hline IR ML 1a & Galena & coarse crystal., stratiform, with barite & 39.36 \\
\hline ML-b & Galena & coarse crystal., stratiform, with barite & 25.10 \\
\hline IL $53-8.40 \mathrm{c}$ & Pyrite & fine, with barite & 21.40 \\
\hline IL 53-11.25b & Pyrite & fine, with dol.+bar. & 21.30 \\
\hline IL 53-15.87 & Pyrite & blades with sphalerite & 20.20 \\
\hline IL $53-15.87 \mathrm{a}$ & Pyrite & massive, irregular & 21.80 \\
\hline IL $53-15.87 b$ & Sphalerite & brown, replacing pyrite & 22.60 \\
\hline IL $53-15.87 \mathrm{c}$ & Sphalerite & yellow green & 21.10 \\
\hline IL $53-15.87 d$ & Galena & fine, with sphalerite + jordanite & 20.30 \\
\hline IL $53-15.87 \mathrm{e}$ & Jordanite & fine, with galena & 21.20 \\
\hline IL $53-17.50 \mathrm{a}$ & Pyrite & coarse, blade, with quartz & 22.10 \\
\hline IL $53-17.50 \mathrm{~b}$ & Sphalerite & fine, with quartz & 20.80 \\
\hline IL $53-17.70 \mathrm{a}$ & Pyrite & coarse, disseminated & 20.60 \\
\hline IL $53-17.70 b$ & Pyrite & fine, disseminated & 22.60 \\
\hline IL $53-17.70 \mathrm{c}$ & Sphalerite & brown, with pyrite + quartz & 22.30 \\
\hline IL 52-14.86a & Pirita & fine with sphalerite & 22.40 \\
\hline IL $52-14.86 b$ & Sphalerite & dissemin. with pyrite & 21.60 \\
\hline IL $35-13.50 \mathrm{a}$ & Galena & nodules: $75 \%$ gal. + sph + py & 21.70 \\
\hline IL $35-13.50 \mathrm{~b}$ & Sulfides & nodules of gal + esf + pir. & 22.50 \\
\hline IL $35-16.78 \mathrm{a}$ & Pyrite & nodules with gypsum + quartz & 19.10 \\
\hline \multicolumn{4}{|c|}{ Nova Redenção } \\
\hline NR AM 4 & Barite & clear gray, with hematite & 39.25 \\
\hline NR $11-11.0$ & Barite & vein, within dolarenite & 40.96 \\
\hline NR 11-1.0 & Barite & vein, within dolarenite & 33.60 \\
\hline NR $11-9.76$ & Barite & vein, within dolarenite & 36.16 \\
\hline NR AM 1 & Galena & coarse, massive, veins & 15.10 \\
\hline NR AM 2 & Galena & fine, pods & 14.38 \\
\hline NR AM 8 & Galena & pods within dolarenite & 6.00 \\
\hline NR $12-25.5 \mathrm{a}$ & Galena & coarse, within dolarenite & 11.72 \\
\hline NR $14-25.9$ & Galena & fine, dissemin. & -0.09 \\
\hline NR AG 1 & Galena & massive, lenses & 15.50 \\
\hline NR AG 2a & Pyrite & massive, with galena & 17.20 \\
\hline NR AG $2 b$ & Galena & massive, lenses & 14.00 \\
\hline NR AG 2c & Sphalerite & massive, lenses & 18.00 \\
\hline
\end{tabular}


Table 2 (continued)

\begin{tabular}{|c|c|c|c|}
\hline & Mineral & Description & $\delta^{34} \mathrm{~S}$ \\
\hline \multicolumn{4}{|l|}{ Nova Redenção } \\
\hline NR AG $3 a$ & Pyrite & massive, lenses & 17.60 \\
\hline NR AG 3b & Galena & massive, lenses & 15.30 \\
\hline NR AG $3 c$ & Sphalerite & massive, lenses & 18.60 \\
\hline NR AG 4a & Pyrite & massive, lenses & 17.30 \\
\hline NR AG $4 b$ & Galena & massive & 15.40 \\
\hline NR AG $4 \mathrm{c}$ & Sphalerite & massive & 16.50 \\
\hline NR $14-25.45 a$ & Galena & fine, within stylolites & 8.10 \\
\hline NR 14-25.45a1 & Galena & medium grain, pods & 9.80 \\
\hline NR $24 \mathrm{a}$ & Galena & massive, lenses & 15.20 \\
\hline NR $25-0.6$ & Galena & massive, lenses & 16.20 \\
\hline \multicolumn{4}{|c|}{ Vale do São Francisco (Iyer et al., 1992) } \\
\hline MM 1 & Galena & - & 26.60 \\
\hline MM 2 & Galena & - & 26.40 \\
\hline MM 3 & Galena & - & 23.10 \\
\hline MM 4 & Galena & - & 26.00 \\
\hline MM 5 & Galena & - & 18.60 \\
\hline MM 6 & Galena & - & 25.60 \\
\hline MM 7 & Galena & - & 27.50 \\
\hline MM 8 & Galena & - & 26.00 \\
\hline MM 9 & Galena & - & 35.50 \\
\hline MM 10 & Galena & - & 18.00 \\
\hline
\end{tabular}

Morro Agudo/Vazante

Morro Agudo, $N$ ore body

MA N

MA N 1a

MA N 1b

Sphalerite

Galena

MA N 1c

MA N 2a

MA N 2b

Pyrite

Sphalerite

MA N 2c

Galena

MA N 3a

Pyrite

Pyrite

MA N 3b

Galena

MA N 4a

Galena

MA N 4b

MA N 5a

Sphalerite

Pyrite

MA N 5b

Sphalerite

MA IC 11a

Sphalerite

MA IC $11 b$

Galena

MA IC $21 b$

Barite

very fine, stratiform

$-0.30$

gal. $(90 \%)+$ esf., fine grain. $\quad-7.50$

fine, dissemin., stratiform $\quad-7.10$

fine, stratiform

0.50

very fine, stratiform

$-4.40$

very fine, stratiform

$-5.00$

fine, stratiform

$-4.90$

fine, stratiform

$-5.20$

very fine grain.

$-1.90$

very fine grain.

2.70

fine, stratiform

1.50

fine, stratiform

0.50

fine, stratiform

$-5.62$

fine, stratiform

$-8.66$

pods

25.40

$M$ ore body

MA IC 9a

MA IC $9 b$

Sphalerite

Galena

pods

38.80

Barite

pods

33.70

pods

23.80

Pyrite

pods

29.58

MA IC 38d

Barita

pods

28.67

JKL ore body

MA JK 1

Galena

coarse, massive

29.40

Galena

coarse, massive

20.90 
Table 2 (continued)

\begin{tabular}{|c|c|c|c|}
\hline & Mineral & Description & $\delta^{34} \mathrm{~S}$ \\
\hline \multicolumn{4}{|l|}{ JKL ore body } \\
\hline MA JK 1a & Galena & massive, fine grain & 22.10 \\
\hline MA JK $1 b$ & Galena & coarse, massive & 19.90 \\
\hline MA JK $1 \mathrm{c}$ & Sphalerite & medium grain., w/ galena & 24.80 \\
\hline MA JK 1d & Pyrite & fine grain., with sphalerite & 22.70 \\
\hline MA JK 2a & Galena & coarse grain., cementing breccia & 19.80 \\
\hline MA JK $2 b$ & Sphalerite & fine grain., cementing breccia & 24.20 \\
\hline MA JK 2c & Barite & veins & 23.10 \\
\hline MA JKL 1a & Sphalerite & fine, dissemin. in dolarenite & 13.90 \\
\hline MA JKL $1 b$ & Galena & fine, in dol. with sphalerite & 10.60 \\
\hline MA JKL 4 & Sphalerite & fine to medium grain., dissemin. & 13.60 \\
\hline MA JKL 5 & Pyrite & massive, stratiform & 14.00 \\
\hline MA IC 2a & Sphalerite & coarse grain., dissemin. & 27.50 \\
\hline MA IC $2 b$ & Galena & fine, within sphalerite & 31.10 \\
\hline MA IC 2c & Barite & lenses + stratif. (JKL ore body) & 21.10 \\
\hline MA IC $3 c$ & Barite & pods, $\mathrm{L}$ ore body & 23.90 \\
\hline MA IC 4c & Barite & within sphalerite & 25.40 \\
\hline MA IC $12 \mathrm{a}$ & Sphalerite & fine, massive & 26.40 \\
\hline MA IC $12 b$ & Galena & fine, massive & 24.72 \\
\hline MA IC $12 \mathrm{c}$ & Pyrite & nodules, within sphalerite & 18.60 \\
\hline MA IC 13a & Sphalerite & & 28.90 \\
\hline MA IC $13 b$ & Galena & & 25.60 \\
\hline MA IC $14 \mathrm{a}$ & Sphalerite & & 20.20 \\
\hline MA IC $14 b$ & Galena & & 16.00 \\
\hline MA IC $15 \mathrm{a}$ & Barite & lenses, stratiform & 15.90 \\
\hline MA IC $15 \mathrm{c}$ & Barite & lenses, stratiform & 19.60 \\
\hline MA IC $16 \mathrm{c}$ & Barite & lenses, stratiform & 20.80 \\
\hline MA IC $33 \mathrm{c}$ & Barite & pods & 14.50 \\
\hline MA IC 34a & Barite & pods & 44.03 \\
\hline \multicolumn{4}{|l|}{ GHI ore body } \\
\hline MA GHI 1a & Barite & pods & 28.50 \\
\hline MA GHI 1b & Galena & pods & 25.30 \\
\hline MA GHI 1c & Sphalerite & pods & 27.90 \\
\hline MA GHI 2 & Barite & pods & 26.30 \\
\hline MA IC $18 \mathrm{a}$ & Sphalerite & pods & 31.70 \\
\hline MA IC $18 b$ & Galena & pods & 34.00 \\
\hline MA IC 44a & Sphalerite & pods & 29.83 \\
\hline MA IC 44b & Galena & pods & 25.80 \\
\hline MA IC $44 \mathrm{c}$ & Barite & pods & 18.59 \\
\hline \multicolumn{4}{|l|}{ Vazante } \\
\hline VZ 01a & Sphalerite & medium grain., in fracture & 15.50 \\
\hline VZ 01b & Galena & medium grain., in fracture & 13.00 \\
\hline VZ 5002 & Sphalerite & coarse grain., in fracture + dissemin. & 16.40 \\
\hline VZ OPEN PIT & Sphalerite & med. to coarse grain., veins with qz. & 15.30 \\
\hline VZ OP 02 & Sphalerite & coarse grain., fracture with qz. & 15.70 \\
\hline
\end{tabular}

(1999) suggested the possibility of reduced sulfur derived from the leaching of basement rocks or from pre-existing sulfides. Their model involves a hydrothermal aqueous solution and sulfate reduction by thermochemical reactions in the presence of $\mathrm{Fe}^{2+}$-bearing minerals.

In summary, the sulfur isotope compositions of the Neoproterozoic sediment hosted base metal 


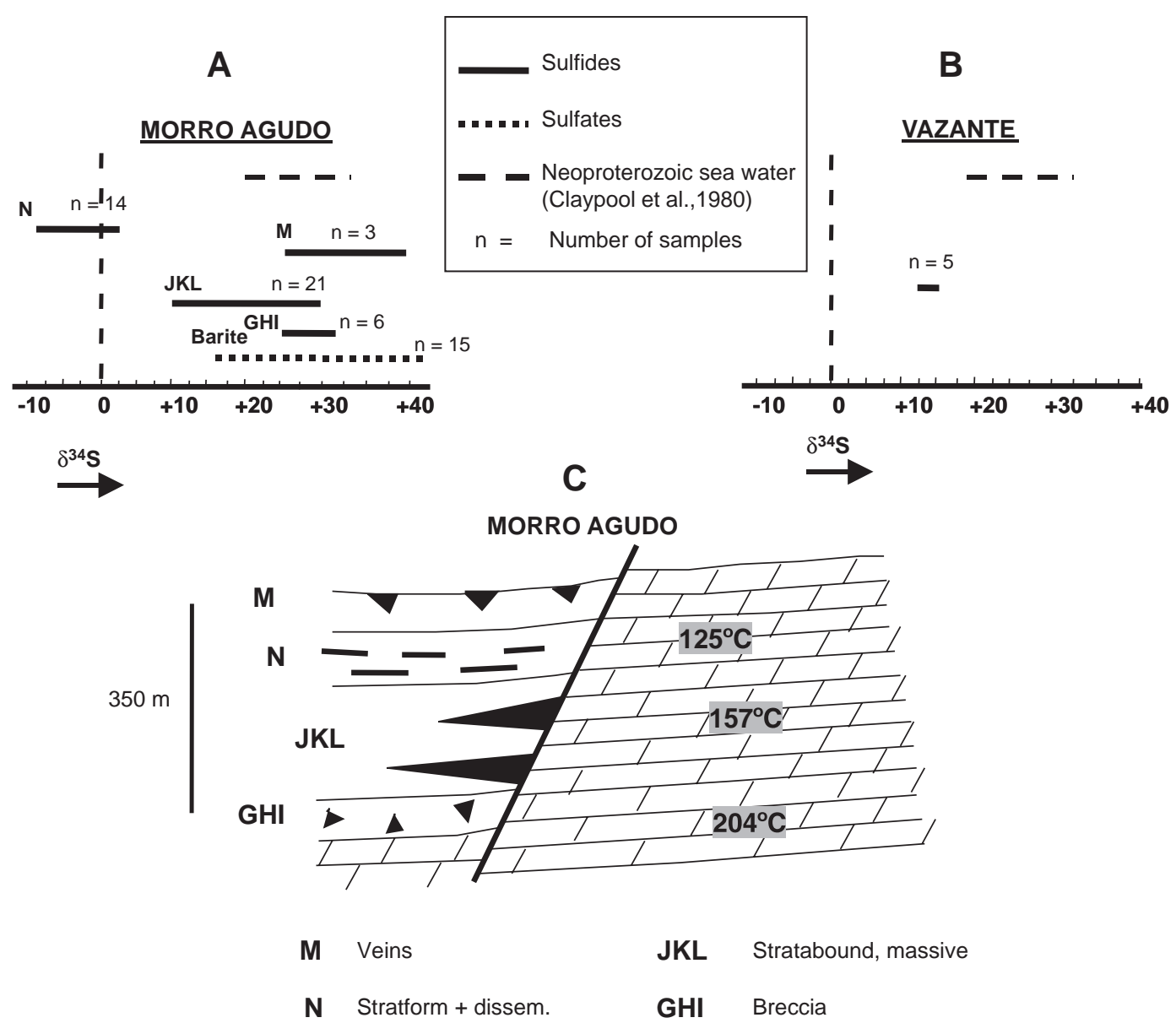

Fig. 18. Sulfur isotopic data of sulfides and sulfates from the $\mathrm{Zn}-\mathrm{Pb}$ deposits of (A) Morro Agudo and (B) Vazante. (C) Schematic representation (not to scale) of the distribution of the deposits in relation to the main fault and the calculated temperatures from co-genetic sulfur isotopic pairs galena-sphalerite. See Fig. 5 and Table 2 for details.

deposits of the São Francisco Craton indicate seawater source of the sulfur. One possible explanation for the enrichment in ${ }^{34} \mathrm{~S}$ of sulfides (and consequently the low fractionation observed between sulfates and sulfides) is that sulfate minerals were thermochemically reduced leading to the formation of the sulfides. Alternatively, when the carbonate was dissolved by the ascending mineralizing fluids, trace sulfate could be released and then thermochemically reduced to form sulfides. No additional isotopic fractionation is required by this process and similarly enriched ${ }^{34} \mathrm{~S}$ could be preserved in the sulfide phase (A.J. Kaufman, personal communication).

\section{Fluid inclusions}

Microthermometric measurements carried out on sphalerite crystals from Morro Agudo (Cunha, 1999; Cunha et al., 2000) and Nova Redenção (Gomes, 1998) deposits were confined to primary and pseudosecondary inclusions in sphalerite crystal aggregates. Inclusions observed in both deposits are of 5 to $10 \mu \mathrm{m}$ in size, with occasional larger ones. They have a variety of shapes (negative crystal, octahedral, sharp tubular and irregular) and, are randomly distributed or formed of intra-granular trails, parallel to the cleavage planes of the crystals. They could be classified into: (1) two-phase inclusions $(\mathrm{L}+\mathrm{V})$, with a degree of 
filling varying from 0.8 to 0.9 ; (2) monophase ( $\mathrm{L}$ or V) inclusions.

During the freezing runs, the monophase inclusions formed vapor bubbles and showed freezing temperature around $-60{ }^{\circ} \mathrm{C}$, suggesting that they were liquid aqueous inclusions which could correspond to two-phase inclusions that were initially in a metastable state. Microthermometric measurements for the Nova Redenção, Morro Agudo and Irecê deposits (Kyle and Misi, 1997) are shown in Table 3. The data for each deposit are discussed below.

\subsection{Nova Redenção}

During heating from very low temperature, several disturbances within the inclusions were observed between -60 and $-6{ }^{\circ} \mathrm{C}$ (Fig. 19A) and these could be related to eutectic temperatures. Half of the inclusions showed only a single phase change (or disturbance) around $-17{ }^{\circ} \mathrm{C}$. The inclusions with two-phase changes, displayed several major temperature peaks (Table 3). If these temperatures are truly eutectic it could suggest the presence of $\mathrm{Ca}$ and $\mathrm{Mg}$ salts in the inclusions. The total homogenization temperatures always occurred to the liquid phase, with temperatures varying from 80 to $210{ }^{\circ} \mathrm{C}$, although most of the data are in a narrower interval of 140 to $190{ }^{\circ} \mathrm{C}$ (Table 3, Fig. 19B).

\subsection{Morro Agudo}

Samples from the eight ore bodies in the blocks A, B and C of the Morro Agudo mine (Fig. 5) have been analyzed. Based on their characteristics, fluid inclusion data for the $\mathrm{G}, \mathrm{H}$ and $\mathrm{I}$ and $\mathrm{J}, \mathrm{K}$ and $\mathrm{L}$ ore bodies can be separated into two distinct groups:
GHI and JKL. The melting temperatures in the inclusions obtained during heating from very low temperatures for the ' $A$ ' and ' $C$ ' blocks of JKL (Fig. 20A) are shown in Table 3. The limited data obtained for inclusions of samples from the ' $\mathrm{B}$ ' block overlap with the ranges for the ' $\mathrm{A}$ ' and ' $\mathrm{C}$ ' blocks. The data from the 'GHI', ' $\mathrm{M}$ ' and ' $\mathrm{N}$ ' (Fig. 20B) ore bodies are presented in Table 3. In all the ore bodies studied the homogenization temperatures were always to the liquid phase (Table 3, Fig. 21A, $\mathrm{B}, \mathrm{C}$ and $\mathrm{D}$ ).

\subsection{Irecê}

Limited fluid inclusion studies were carried out on sphalerite crystal aggregates from the Rufino prospect. According to Kyle and Misi (1997), liquidvapor primary fluid inclusions are not abundant and their size varies from 2 to $4 \mu \mathrm{m}$. Homogenization temperatures are between 140 and $200{ }^{\circ} \mathrm{C}$. Limited determinations of final ice melting temperatures (Table 3) indicate a salinity ranging from 3 to 10 wt. $\% \mathrm{NaCl}$ equivalent.

\subsection{Interpretation}

A model composition for the studied inclusions may be ascertained from the first low stable melting temperatures during warming (eutectic temperature$\left.T_{\mathrm{e}}\right)$. According to Davis et al. (1990) and Oakes (1997), low eutectic temperatures are consistent with the topologies of the $\mathrm{NaCl}+\mathrm{CaCl}_{2}+\mathrm{H}_{2} \mathrm{O}$, $\mathrm{NaCl}+\mathrm{MgCl}_{2}+\mathrm{H}_{2} \mathrm{O}$, and probably other ternary or higher order systems. However, in general, the metastability of the saline inclusions makes $T_{\mathrm{e}}$ hard to determine, as the values measured may relate to

Table 3

Fluid inclusion data for Nova Redenção (NR), Morro Agudo (MA) and Irecê deposits

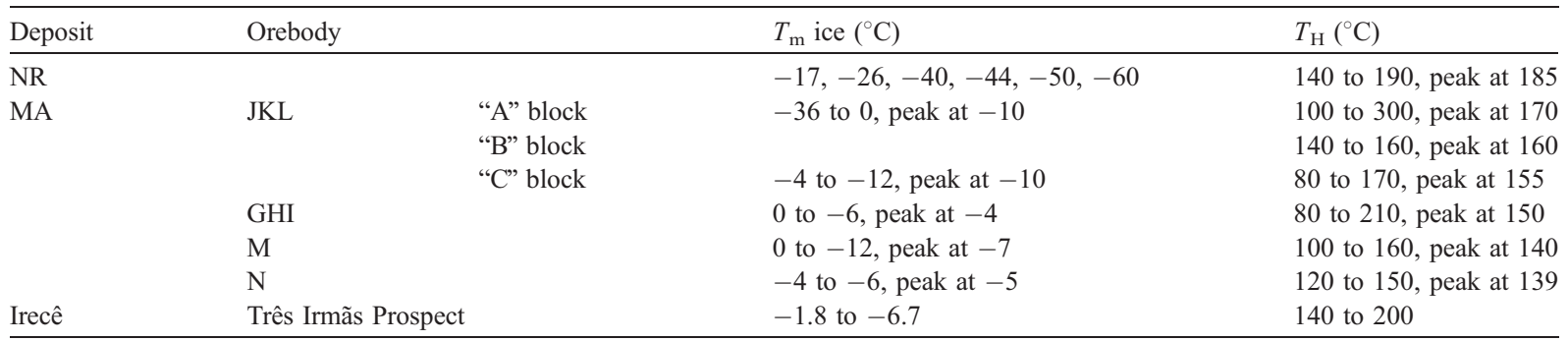



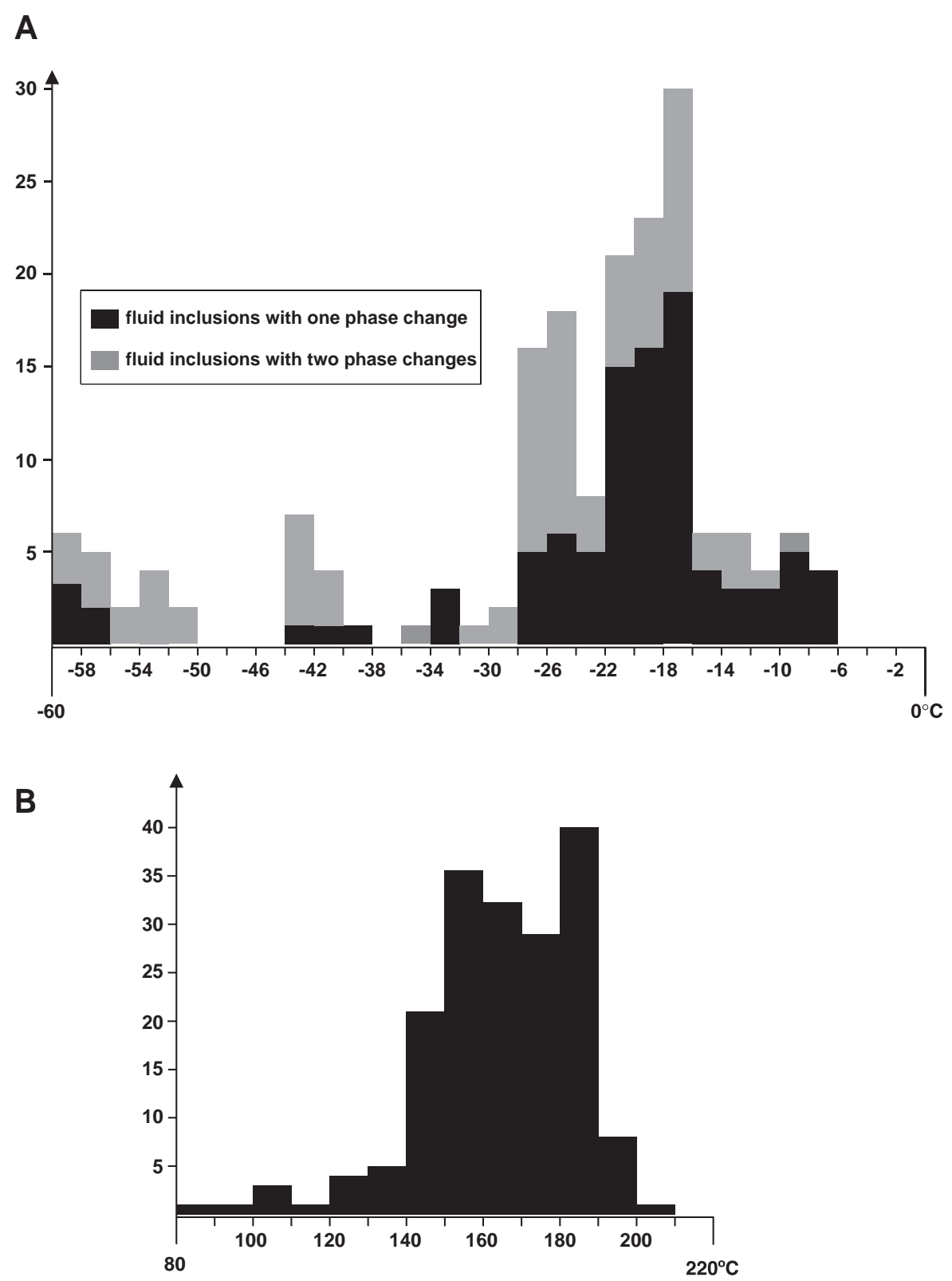

Fig. 19. (A) Frequency distribution diagram of phase change temperatures during heating from very low temperatures at Nova Redenção deposit. (B) Frequency distribution diagram of homogenization temperatures. After Gomes (1998).

the temperatures of various physical changes of solids such as recrystallization and devitrification. Only modern high-resolution microscopes equipped with video cameras and high magnification objectives are capable of differentiating between the two phenomena (Burrus, 1997; Bodnar, 1998). In addi- tion, the small size of the inclusions and the dark color of the host sphalerite crystals render the $T_{\mathrm{e}}$ determination in the inclusions in samples from Nova Redenção and Morro Agudo deposits difficult. Thus, the temperatures of low phase change recorded in the fluid inclusions could correspond either to 


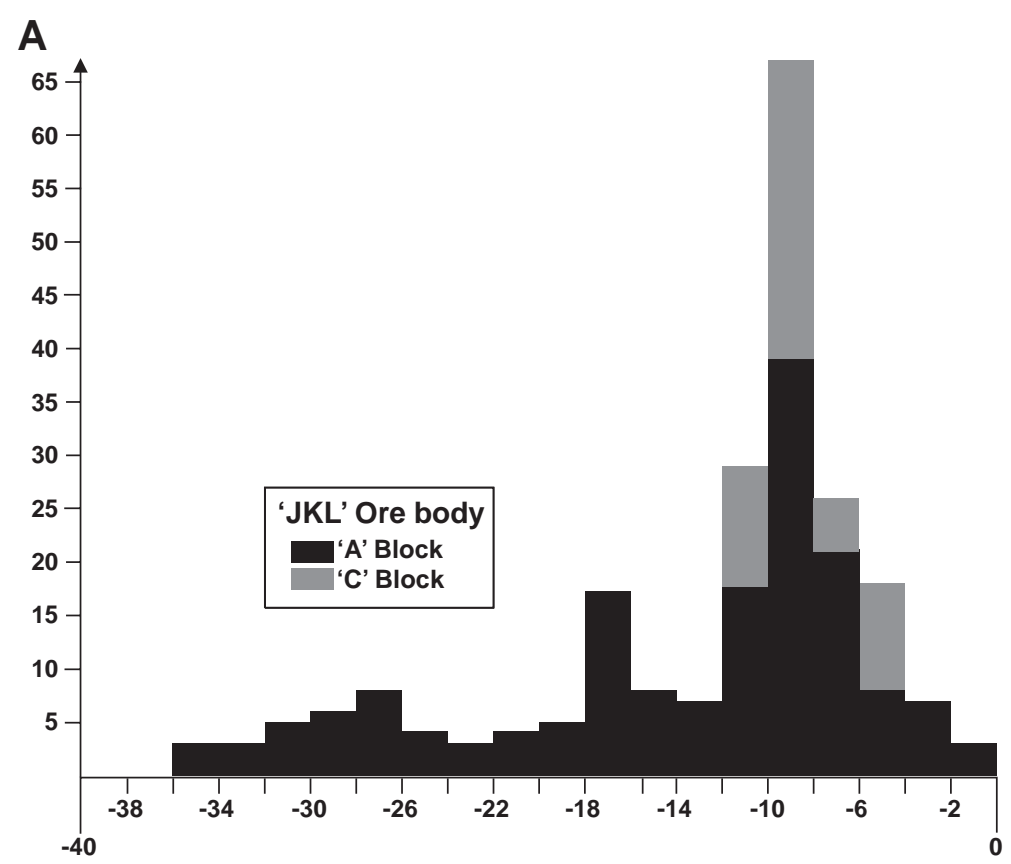

B
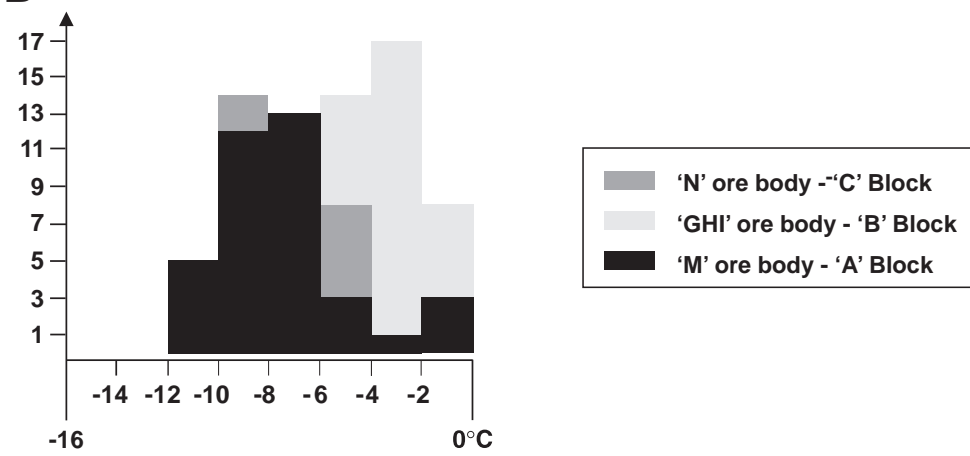

Fig. 20. Frequency distribution diagram of phase change temperatures during heating from very low temperatures: (A) JKL ore body; (B) GHI, $\mathrm{M}$ and $\mathrm{N}$ ore bodies. After Cunha (1999).

physical changes or to eutectic values (stable or metastable). We assume the $\mathrm{NaCl}-\mathrm{H}_{2} \mathrm{O}$ system as the composition model and disregard all temperatures below $-21.2{ }^{\circ} \mathrm{C}$ in the salinity calculation.

For the Nova Redenção deposit the calculated salinity of inclusions showing just a single phase change (assuming ice as the last crystal to melt) varied from 10.3 to 23.3 wt.\% eq. $\mathrm{NaCl}$. For the inclusions yielding melting temperatures below $-21.2{ }^{\circ} \mathrm{C}$, the equations of Oakes et al. (1990) were not applied for salinity calculations as stable eutectic temperature of the antarcticite could not be observed.
The melting temperatures of the solids in fluid inclusions from the JKL orebodies in the $\mathrm{A}$ and $\mathrm{C}$ blocks at Morro Agudo deposit, yielded average salinity of 12.85 wt.\% eq. $\mathrm{NaCl}$, or 24.81 wt.\% eq. $\mathrm{NaCl}$ assuming ice or hydrohalite as the last phase to melt. Similarly the average salinity for the 'M', 'N' and GHI orebodies obtained were 11.7 wt.\% eq. $\mathrm{NaCl}, 7.8$ and 4.9 wt.\% eq. $\mathrm{NaCl}$, respectively.

The homogenization temperature $\left(T_{\mathrm{h}}\right)$ data in 'JKL' orebodies of the Morro Agudo deposit exhibit a lateral thermal zonation with respect to the fault zone with a decrease in $T_{\mathrm{h}}$ values away from the fault zone. The 
A

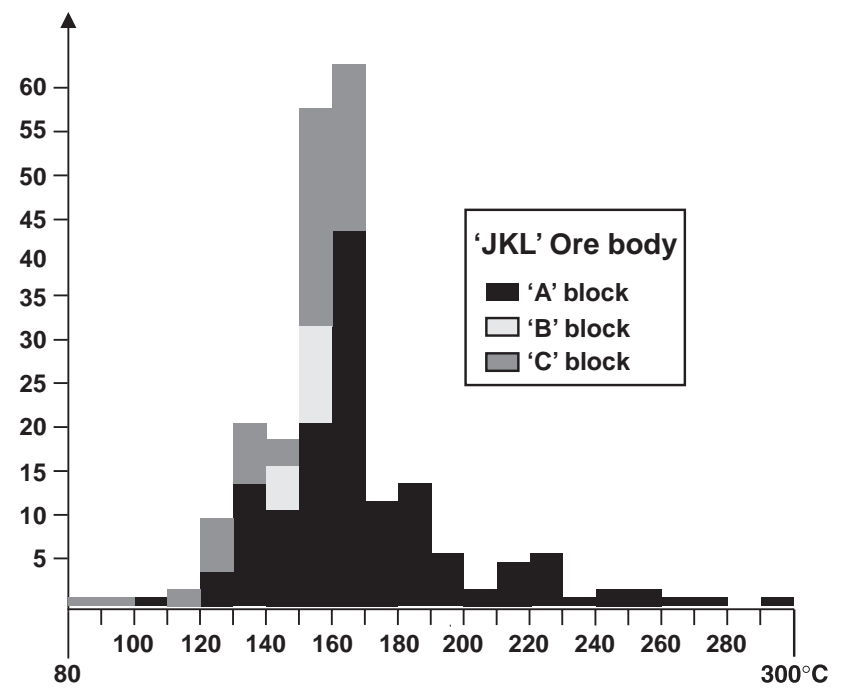

B
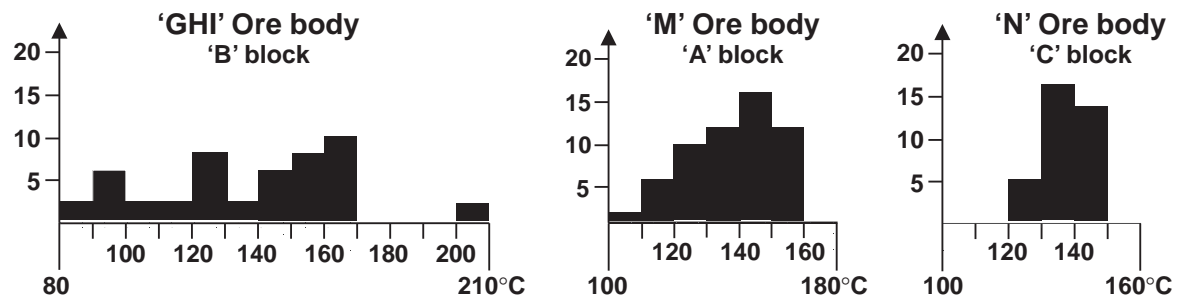

Fig. 21. Frequency distribution diagram of homogenization temperatures at Morro Agudo (A) 'JKL' ore body; (B) 'GHI', 'M' and 'N' ore bodies. After Cunha (1999).

data obtained from the 'GHI', 'M' and ' $\mathrm{N}$ ' orebodies also exhibit a vertical zoning. The temperatures measured from fluid inclusions are concordant with the values calculated from the sulfur isotopic fractionation in cogenetic pairs of sphalerite-galena (Table 4).

\section{Discussion and conclusions}

\subsection{Common geological characteristics of the deposits}

The $\mathrm{Pb}-\mathrm{Zn}$ deposits studied are distributed over a large area in the São Francisco Craton and share a number of geological features and mineralogical characteristics. These include host rock and strati-
Table 4

Geothermometric data calculated from $\delta^{34} \mathrm{~S}$ fractionation of cogenetic pairs (see Table 2) using Ohmoto and Rye (1979) equation, compared with homogenization temperature measured in primary fluid inclusions of sphalerites of the same samples $(\mathrm{NR}=$ Nova Redenção; MA=Morro Agudo)

\begin{tabular}{lll}
\hline Sample & $\begin{array}{l}\text { Temperature }\left({ }^{\circ} \mathrm{C}\right) \\
\left(\delta^{34} \mathrm{~S}_{\text {sph-gal }}=\right. \\
\left.0.73 \times 10^{6} / T^{2}\right)\end{array}$ & $\begin{array}{l}\text { Temperature }\left({ }^{\circ} \mathrm{C}\right) \\
\left(T_{\mathrm{h}} \text { : mode and }\right. \\
\text { range })\end{array}$ \\
\hline NR AG 2b & 154 & $160(140-190)$ \\
NR AG 3b & 187 & - \\
MA JK 1 & 113 & $175(117-278)$ \\
MA IC 9 & 105 & $136(133-141)$ \\
MA IC 11 & - & $139(138-139)$ \\
MA GHI 11 & 256 & $136(90-209)$ \\
MA IC 13 & 197 & $154(148-156)$ \\
MA IC 14 & 144 & $158(137-167)$ \\
MA N 4 & 125 & $138(137-167)$ \\
\hline
\end{tabular}


graphic control: shallow water marine carbonates, mainly of dolomitic type, associated with an organic-rich facies: stromatolitic structures, black micritic and oolitic carbonates, or black shales with disseminated pyrite. The presence of nodules of length-slow microquartz, gypsum, sulfides pseudomorph after sulfates, teepee structures and dissolution breccias indicate the intimate association of host rocks with an evaporitic environment. The evaporites and dolomites correspond to an end member of a regressive megacycle, which is well represented in the Neoproterozoic basins of the São Francisco Craton. They are overlain by organic-rich pelites, representing a rising sea level (Fig. 3).

The majority of the deposits display a very distinct structural control. Fractures and faults oriented $\mathrm{N} 20-50^{\circ} \mathrm{W}$ for Nova Redenção and Serra do Ramalho/Montalvânia deposits (Gomes, 1998; Misi, 1999; Misi et al., 2000). At Irecê, the intense folding masks any pronounced original lineament. However, Landsat images show a regional N40 $50^{\circ} \mathrm{W}$ fracture/fault system, with which most of the deposits and occurrences are associated (FrancaRocha, 2001). Syn-sedimentary normal faults trend $\mathrm{N} 10-20^{\circ} \mathrm{W}$ for the Morro Agudo deposits (Dardenne, 2000). The main fault in this system is interpreted as a feeder zone (Cunha, 1999; Misi et al., 1999). The sinistral transcurrent fault trending $\mathrm{N} 45-50^{\circ} \mathrm{E}$ was originally related to syn-sedimentary growth faults for the Vazante deposits (Hitzman, 1997; Dardenne, 2000).

Fig. 1 shows that some of the linear structures associated with the mineralization crosscut the sedimentary basin and its basement, implying that they were active at least until the end of the basin infill. These structures apparently had their origin during the basement induced extensional processes that have been active during the major period of sedimentation. Inversion from extensional to compressional tectonics occurred during late Brasiliano orogeny (Alkmim et al., 1996; Hitzman, 1997). Initial accumulation of metals took place during the development of the extensional process.

The $\mathrm{N} 20-50^{\circ} \mathrm{W}$ trending faults and fractures controlling the emplacement of the Neoproterozoic $\mathrm{Pb}-\mathrm{Zn}$ deposits in the carbonate platform are approximately parallel to the $1.8-1.7 \mathrm{Ga}$ Espinhaço rift (Paramirim Valley, Fig. 1). These structures were reactivated during the formation and evolution of the Neoproterozoic basins, during which the mobilization of metals from the basement source rocks took place and the ore deposits were formed.

A further shared characteristic is the ore mineral and gangue association: With the exception of the Vazante mine, where primary mineralization is essentially silicate (willemite), pyrite, galena and sphalerite represent the main mineral association in all other deposits. In Morro Agudo and Irecê, sphalerite represents the major sulfide, while galena is the dominant phase in Nova Redenção, Montalvânia, and Januária/Itacarambi. The most common gangue minerals are calcite, dolomite, quartz (mega and microquartz), and barite.

Lastly, stratiform mineralization is present in all deposits, along with irregular patches and discordant veins of disseminated or massive sulfides.

\subsection{Metallogenic evolution model}

The common characteristics of the ore deposits described above allow the development of an integrated metallogenic evolution model. Though many questions still persist we attempt here to answer some of the questions raised.

\subsubsection{Ore fluid composition and temperatures of deposition}

Homogenization temperatures $\left(T_{\mathrm{h}}\right)$ and salinity of the primary and pseudosecondary fluids in sphalerite samples of the deposits studied yielded similar values. In a diagram showing $T_{\mathrm{h}}$ plotted against salinity for MVT, SEDEX and 'Irish' type deposits (Fig. 22) the deposits of the São Francisco Craton fall in the field designated for the 'Irish' deposits.

\subsubsection{Source of metals}

In all the deposits the $\mathrm{Pb}$ isotope data plot above the $\mathrm{Pb}$ isotope evolution curves of Zartman and Doe (1981), implying the derivation of metals from upper crustal sources. Although the data points show a large spread, the scatter is limited for individual deposits, indicating a relatively uniform metal source for a given deposit. The São Francisco Valley and Irecê deposits contain highly radiogenic lead, while those of Vazante, Morro Agudo and some others are less radiogenic. Such a difference 


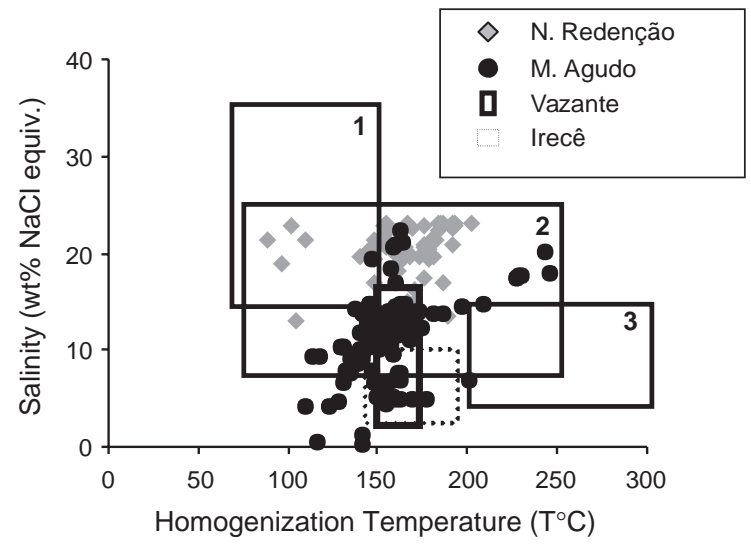

Fig. 22. Homogenization temperatures and salinity from primary and pseudo-secondary fluid inclusions in sphalerite crystals from the deposits studied and comparison with the databank of classical models of sediment-hosted sulfide deposits (Goodfellow et al., 1993; Hitzman, 1995). Range for willemite of the Vazante mine from Dardenne and Freitas-Silva (1999) and for sulfides of Irecê from Kyle and Misi (1997). (1) Mississippi Valley type (MVT); (2) 'Irish type'; (3) SEDEX type. After Misi et al. (2000).

may be explained by (i) the nature (concentration of heat producing elements) of the source rock from which $\mathrm{Pb}$ was derived and, (ii) the process involved during the mobilization of lead from the basement (Iyer, 1984). The interaction of the mineralizing solutions for a shorter period of time with the basement rocks preferentially removes loosely held radiogenic lead from radioactive minerals, while prolonged attack by solutions would release tightly held nonradiogenic lead from minerals like feldspar.

From the dispersion of the $\mathrm{Pb}$ isotope data in the secondary isochron for galena in the Irecê Basin, an age of $\sim 1.7 \mathrm{Ga}$. could be inferred for the source rocks that supplied $\mathrm{Pb}$ to the ore minerals. This age coincides with an important geological episode during which highly radioactive alkaline to subalkaline granites of crustal origin were intruded. A good example is the Lagoa Real Granite Complex whose origin is related to the Rio dos Remédios volcanism occurring mainly in the Paramirim Valley. These radioactively enriched granitic bodies $(U=4$ to $20 \mathrm{ppm}$ and $\mathrm{Th}=15$ to $76 \mathrm{ppm}$; Maruéjol et al., 1987) are part of an alkaline/sub-alkaline magmatism related to underplating. Given the regional importance of this magmatism it is possible that similar granitic bodies intruded different parts of the São Francisco Craton. The role of these rocks in modifying the paleo-geothermal gradient of the São Francisco Craton and their influence on ore formation will be discussed in Section 7.2.4.

\subsubsection{Source of sulfur and reduction mechanism}

Geological and petrographic investigations reveal that the deposits are clearly associated with evaporitic rocks, suggesting a marine origin for the sulfur. The $\delta^{34} \mathrm{~S}$ values of sulfates (layered, nodule and pods) are in the range expected for the Neoproterozoic seawater (Claypool et al., 1980). The absence of a correlation between $\delta^{34} \mathrm{~S}$ and ${ }^{206} \mathrm{~Pb} /{ }^{204} \mathrm{~Pb}$ observed for some of the sulfides (Fig. 23) indicates that lead and sulfur are derived from two independent sources, as suggested by Iyer et al. (1992) for the São Francisco Valley deposits.

The concordant high temperatures obtained for the ore deposition from fluid inclusion study and sulfur isotope fractionation of coexisting sulfide pairs and the association of organic matter with the carbonates hosting the ore deposits suggest that sulfides may have formed by thermochemical reduction of sulfates.

In the Morro Agudo deposit the process of ore formation appears to be more complex and requires further investigation. The $\delta^{34} \mathrm{~S}$ values of the sulfides at Morro Agudo vary according to the morphology of the orebody and its proximity to the main fault. The zonation in $\delta^{34} \mathrm{~S}$ along the vertical (close to 100 $\mathrm{m}$ ) and horizontal (close to $120 \mathrm{~m}$ ) directions mark the deposit and extends to a hand specimen of galena from the "JKL" orebody ( $\mathrm{Li}$ et al., 1996). This suggests the participation of more than one sulfur

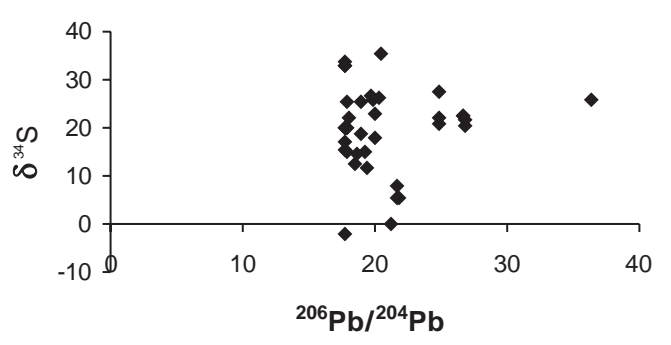

Fig. 23. Plot $\delta^{34} \mathrm{~S}$ vs. ${ }^{206} \mathrm{~Pb} /{ }^{204} \mathrm{~Pb}$ of sulfides from the deposits studied. Note the complete absence of correlation between the data, suggesting different sources for metals and sulfur. 
source, with distinct $\delta^{34} \mathrm{~S}$ values. One of the likely major sources is seawater sulfate, while other possible sources involve circulating metal-bearing mineralizing fluids. The high positive $\delta^{34} \mathrm{~S}$ value near the fault zone and the zonation of the isotopic ratios may be explained by the mixing of ${ }^{34} \mathrm{~S}$ enriched marine sulfate with less enriched sulfur of circulating hydrothermal fluids. Contrary to the interpretation of Romagna and Costa (1988), the deposits related to the " $\mathrm{M}$ " orebody do not appear to be remobilized, but could have the same or a similar origin as the "N" orebody. Their position close to the main fault and high temperature values (up to 140 ${ }^{\circ} \mathrm{C}$ ) obtained from fluid inclusions from sphalerite crystals, are further evidence of the primary nature of the "M" orebody.

A similar scenario prevails in the $\mathrm{Zn}-\mathrm{Pb}$ deposit of Navan, Ireland, where the dominant bacterially reduced marine sulfate is interpreted to be mixed with minor hydrothermal sulfur (Anderson et al., 1998). In the Navan deposit of Ireland the range of temperatures (150 to $\left.260{ }^{\circ} \mathrm{C}\right)$ obtained by fluid inclusion studies is similar to that obtained for the Morro Agudo deposits.

In Vazante, the mineralization is mainly willemite, though minor amounts of sphalerite and galena are present. Recent investigations by Monteiro (1997), Hitzman (1997) and Monteiro et al. (1999) have shown that willemite is primary and was not formed by replacement, as had been earlier speculated. Though the $\delta^{34} \mathrm{~S}$ values of sphalerite and galena from Vazante are less enriched compared to the sulfides from Morro Agudo, the values are still positive. Low concentration of dissolved sulfur in the hydrothermal solution could have led to the precipitation of silicate mineral. The association of hematite and $\mathrm{Zn}$-silicate in Vazante suggests ore precipitation under conditions of high oxygen fugacity with rapid cooling (Hitzman, 1997).

\subsubsection{Geothermal regime in the São Francisco Craton and fluid circulation}

On the Bouguer gravity map of the São Francisco Craton (Ussami, 1993), the deposits of Irecê, Nova Redenção, Serra do Ramalho, Itacarambi and some other occurrences of the São Francisco Basin are associated with negative gravity anomalies of amplitudes below $-65 \mathrm{mGal}$ and with circular to oval- shaped features (Fig. 24). Misi (1999) and Misi et al. (2000) suggested a link between the above deposits and the underlying rock bodies causing the anomalies. In this region, strong negative Bouguer anomalies of this kind are also associated with uranium-rich granites. In addition, the high homogenization temperature values obtained in primary fluid inclusions of sphalerite crystals in the deposits of Nova Redenção and Irecê point to the participation of a high temperature source in the formation of the deposits. Fehn et al. (1978) and O'Connor (1986) suggested that the anomalously high temperatures observed in some sedimentary sequences originate from $\mathrm{U}-\mathrm{Th}-\mathrm{K}$ rich granites ( $\mathrm{U}>6 \mathrm{ppm}$ and/or $\mathrm{Th}>25 \mathrm{ppm}$ ), forming part of the basement and lying directly underneath the sedimentary basin. The high radiogenic heat generated by these granites is retained for long periods of time and may be liberated during a late episode of fracturing. Elevated heat flows of $60 \mathrm{~mW} \mathrm{~m}{ }^{-2}$ are normally associated with this kind of granites (Fehn, 1985). Sangster et al. (1998) referred to the granites underlying the sediment-hosted base metal deposits of Gays River, Walton and Jubilee in Nova Scotia, Canada with strong negative Bouguer anomalies as "high heat production granites (HHP)". The K-rich nature of these rocks enhances the total radiogenic heat production budget, providing energy for fluid circulation and possibly serving as sources of lead and zinc.

Using the $\mathrm{Pb}$ isotope of the whole rock samples spanning ages of $3.2 \mathrm{Ga}$ to $0.65 \mathrm{Ga}$., Iyer and Hamza (1992) and Iyer et al. (1996) calculated the present and paleo radiogenic heat production and heat flux values for the Contendas-Mirante and Jequié Complexes of the São Francisco Craton. The paleo heat flow values of 90 to $100 \mathrm{~mW} \mathrm{~m}^{-2}$ obtained for the Jequié granulite terrain are much higher than those of granulite facies terrains from other parts of the world. From the heat flow and radiogenic heat production data, a geotherm was constructed and the thickness of the lithosphere calculated using the method of Oxburgh (1981) and Gupta et al. (1991). The calculations demonstrated the presence of a thin lithosphere in the Archean and subsequent thickening by crustal underplating and intrusions during the Proterozoic. Thus the radioactively enriched crust, a high geothermal gradient, the negative Bouguer anomalies in the São Francisco Craton along with 


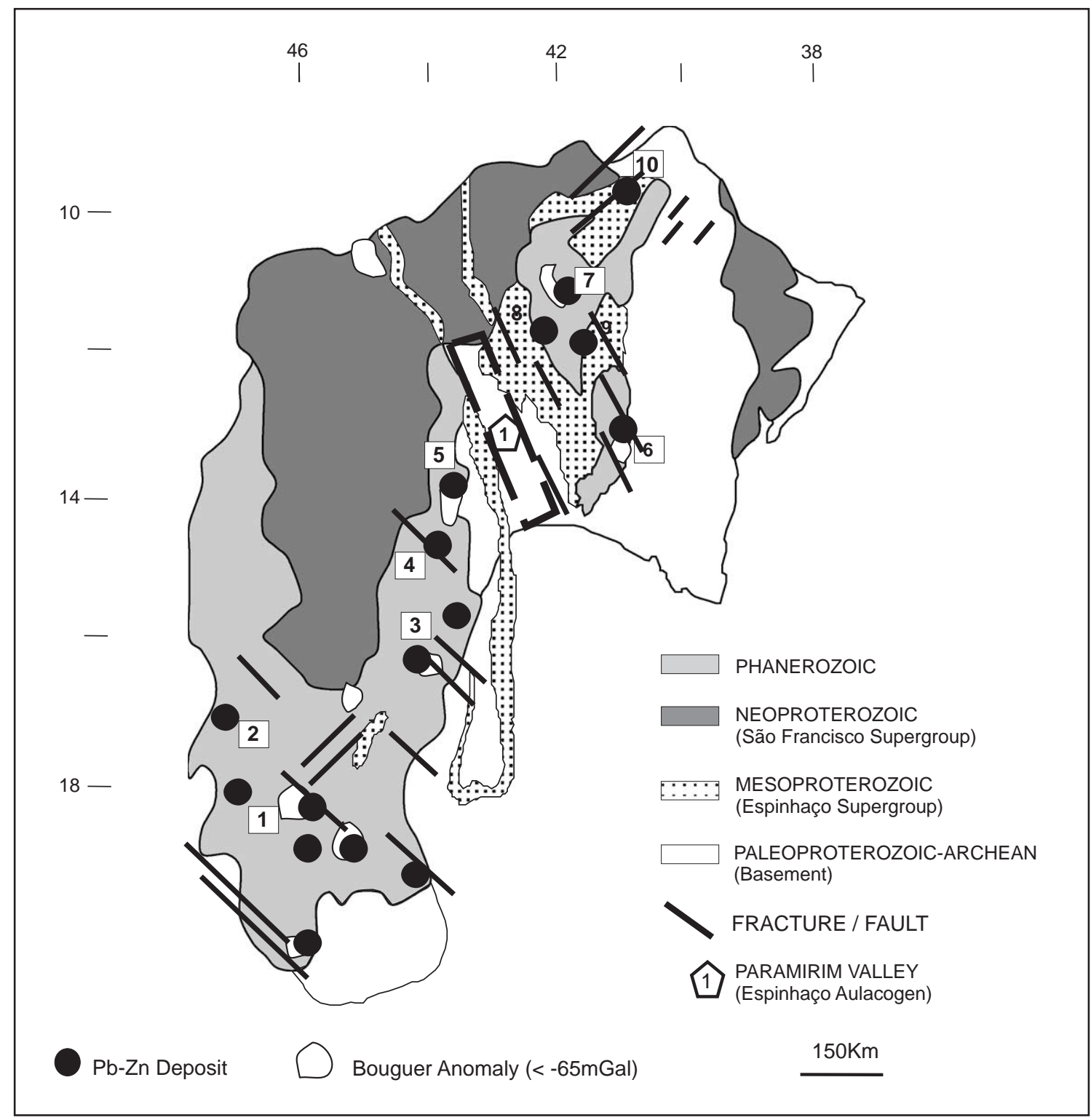

Fig. 24. The zinc-lead deposits of the Neoproterozoic sedimentary cover of the São Francisco Craton and its association with oval-shaped negative Bouguer anomaly (<-65 Mgal). Gravity data from Ussami (1993). See Fig. 1 for deposit names.

the high temperature values obtained from fluid inclusion studies of sphalerite crystals, should be considered in developing and applying regional metallogenic models.

A preliminary and simplified representation of a regional metallogenic model applied to the Neoproterozoic $\mathrm{Pb}-\mathrm{Zn}$ deposits of the São Francisco Craton, as above discussed, is shown in Fig. 25.

\section{Acknowledgements}

The study was carried out under the auspices of (a) "Financiadora de Estudos e Projetos" (FINEP/ PADCT III) grant no. 64.99.0264.00, (b) Conselho Nacional de Desenvolvimento Científico e Tecnológico $(\mathrm{CNPq})$, the national research agency of Brazil and (c) UNESCO/IGCP Project 450 "Proterozoic 


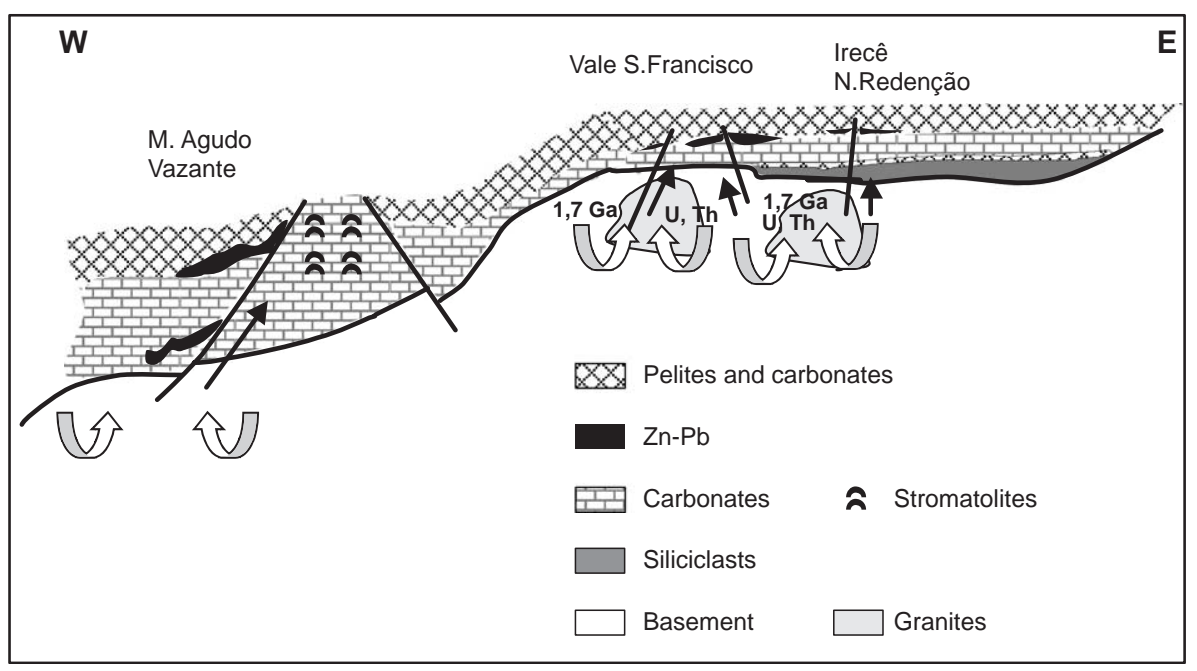

Fig. 25. A metallogenic evolution model (simplified) for the Neoproterozoic sediment-hosted Zn-Pb deposits of the São Francisco Craton. Modified after Misi (1999) and Misi et al. (2000).

sediment hosted base metal deposits of Western Gondwana". Acknowledgements are made to Companhia Baiana de Pesquisa Mineral (CBPM), Companhia Mineira de Metais (CMM), the Geological Survey of Brazil (CPRM) and to Geologia e Sondagens Ltda. (GEOSOL). John Ross made valuable suggestions on an earlier draft of the manuscript. M.G. Silva and A.J. Kaufman provided valuable input into some aspects of the interpretations. A.B. Kampunzu, N.J. Cook and two anonymous reviewers improved the manuscript and made important suggestions.

\section{References}

Alkmim, F.F., Chemale Jr., F., Endo, I., 1996. A deformação das coberturas proterozóicas do Craton do São Francisco e o seu significado tectônico. Revista da Escola de Minas (Ouro-Preto) $49,22-38$.

Almeida, F.F., Hasui, Y. (Eds.), 1984. O Precambriano do Brasil. Blücher Editora, São Paulo. 337 pp.

Amaral, G., 1968. Aplicação do estudo da composição isotópica do chumbo a problemas metalogenéticos: resultados preliminares para galenas de depósitos do Grupo Bambuí. Proceedings of the XXII Congresso Brasileiro de Geologia. Sociedade Brasileira de Geologia, SBG-MG, Belo Horizonte, pp. 131-138.

Anderson, I.K., Ashton, J.H., Boyce, A.J., Fallick, A.E., Russell, M.J., 1998. Ore depositional processes in the Navan $\mathrm{Zn}-\mathrm{Pb}$ deposit Ireland. Economic Geology 93, 535-563.
Azmy, K., Veizer, J., Misi, A., Oliveira, T.F., Sanches, A.L., Dardenne, M.A., 2001. Dolomitization and isotope stratigraphy of the Vazante Formation, São Francisco Basin, Brazil. In: Misi, A., Teixeira, J.B.G. (Eds.), Proterozoic Base Metal Deposits of Africa and South America. Proceedings of the First IGCP 450 Field Workshop. CNPq/UNESCO/IUGS, Belo Horizonte and Paracatu (MG), Brazil, pp. 36-37.

Babinski, M. 1993. Idades isocrônicas $\mathrm{Pb} / \mathrm{Pb}$ e geoquímica isotópica de $\mathrm{Pb}$ nas rochas carbonáticas do Grupo Bambuí na porção sul da bacia do São Francisco. Unpublished $\mathrm{PhD}$ thesis, Universidade de São Paulo, SP, 133 pp.

Babinski, M., Kaufman, A.J., 2003. First direct dating of a Neoproterozoic post-glacigenic cap carbonate. IV South American Symposium on Isotope Geology, Short Papers, vol. 1, pp. $321-323$.

Barbosa, J.S.F., 1986. Constitution lithologique et métamorphique de la région granulitique du sud de Bahia, Brésil. Unpublished $\mathrm{PhD}$ thesis, Université Paris VI, 300 pp.

Barbosa, J.S.F., Dominguez, J.M.L., 1996. Mapa Geológico do Estado da Bahia, Texto Explicativo. Superintendência de Geologia e Mineração (SGM) and Universidade Federal da Bahia, Curso de Pós-Graduação em Geologia, Salvador (BA), 188 pp.

Beurlen, H., 1974. Sobre a origem singenético-sedimentar de alguns corpos mineralizados em chumbo, zinco e fluorita no Grupo Bambuí e dispersão geoquímica primária dos elementos mineralizantes. Proceedings of the XXVII Congresso Brasileiro de Geologia, Sociedade Brasileira de Geologia, SBG-RS, vol. 6, pp. $49-60$.

Bodnar, R.J., 1998. Additional discussion of apparent low temperature observations. Fluid Inclusions Web site: http:// www.geology.wisc.edu/ pbrown/fi.html (accessed February 1998).

Brasier, M.D., Shields, G., 2000. Neoproterozoic chemostratigraphy and correlation of the Port Askaig glaciation, Dalradian Super- 
group of Scotland. Journal of the Geological Society (London) 157, 909-914.

Brito Neves, B.B., 1975. Regionalização Tectônica do Precambriano Nordestino. Unpublished $\mathrm{PhD}$ thesis. Universidade de São Paulo, SP, 198 pp.

Brito Neves, B.B., Campos Neto, M.C., Fuck, R.A., 2000. From Rodinia to Western Gondwana: an approach to the Brasiliano-Pan African Cycle and orogenic collage. Episodes 22, $155-166$.

Burrus, R.C., 1997. Short discussion of apparent low eutectic temperature observations. Fluid Inclusions Web site: http:// www.geology.wisc.edu/ pprown/fi.html (accessed June 1997).

Cassedanne, J.P., 1972. Les gites de plomb et zinc du Brésil et leur répartition linéamentaire. These Doctorat d'État, Universite Clermont-Ferrand, France, 336 pp.

Cassedanne, J., Lassère, M., 1969. Étude géologique et analyse isotopique par la méthode au plomb de quelques galenes du Brésil. Bulletin du Bureau de Récherches Géologiques et Minires. Série 2, Section 4, 71-87.

Chang, H.K., 1997. Isótopos estáveis (C, H, O e ${ }^{87} \mathrm{Sr} /{ }^{86} \mathrm{Sr}$ ): implicações na estratigrafia e na paleo-circulação de fluidos da Bacia do São Francisco. Tese de Livre Docência, Universidade Estadual Paulista Rio Claro, SP, Brazil, 129 pp.

Claypool, G.H., Holser, W.T., Kaplan, I.R., Sakai, H., Zak, I., 1980. The age curves of sulfur and oxygen isotopes in marine sulfate and their mutual interpretation. Chemical Geology 28, $199-260$.

Conceição Filho, V.M., Monteiro, M.D., Carvalho, M.P., Souza, W.S.T., 1993. Geologia e potencialidade para mineralizações de cobre, chumbo, zinco e prata da borda norte da Chapada Diamantina, Bahia. Companhia Baiana de Pesquisa Mineral (CBPM), Salvador, Série Arquivos Abertos no. 1, 24 pp.

Condie, K.C., 2002. The supercontinent cycle: are there two patterns of cyclicity? Journal of African Earth Sciences, 35, $179-183$.

Cordani, U.G., Iyer, S.S., Taylor, P.N., Kawashita, K., Sato, K., Mcreath, I., 1992. Pb-Pb, Rb-Sr, and K-Ar systematic of the Lagoa Real Uranium Province (South Central Bahia, Brazil) and the Espinhaço Cycle (ca. 1.5-1.0 Ga). Journal of South American Earth Sciences 5, 33-46.

Cordani, U.G., Milani, E.J., Thomaz-Filho, A., Campos, D.A. (Eds.), 2000. Tectonic Evolution of South America, International Geological Congress, vol. 31. Brazilian Academy of Sciences, Rio de Janeiro, 854 pp.

Cumming, G.L., Richards, J.R., 1975. Ore lead isotope relations in a continuous changing Earth. Earth and Planetary Science Letters $28,155-171$.

Cunha, I.A., 1999. Estudos de inclusões fluidas e de isótopos de enxofre dos corpos de minério de Morro Agudo, Minas Gerais. Dissertação de Mestrado (M.Sc.), Curso de Pós-Graduação em Geologia, Universidade Federal da Bahia Salvador, BA, 105 pp.

Cunha, I.A., Coelho, C.E.S., Misi, A., 2000. Fluid inclusion study of the Morro Agudo $\mathrm{Pb}-\mathrm{Zn}$ deposit, Minas Gerais, Brazil. Revista Brasileira de Geociências 30, 318-321.

Cunha, I.A., Misi, A., Babinski, M., 2001. Lead isotope signatures of galenas from the Morro Agudo $\mathrm{Pb}-\mathrm{Zn}$ deposits, Minas Gerais, Brazil. In: Misi, A., Teixeira, J.B.G. (Eds.), Proterozoic
Base Metal Deposits of Africa and South America. Proceedings of the First IGCP 450 Field Workshop. CNPq/UNESCO/IUGS, Belo Horizonte and Paracatu (MG), Brazil, pp. 45-47.

Dardenne, M.A., 1978. Síntese sobre a estratigrafia do Grupo Bambuí no Brasil central. Proceedings of the XXXI Congresso Brasileiro de Geologia, vol. 2. Sociedade Brasileira de Geologia, SBG-NE, Recife, pp. 597-610.

Dardenne, M.A., 1979. Les minéralisations de plomb, zinc, fluor du Protérozoique Supérieur dans le Brésil Central. Thse de Doctorat (PhD Dissertation), Université Paris VI, France, $251 \mathrm{pp}$.

Dardenne, M.A., 2000. The Brasilia fold belt. In: Cordani, U.G., Milani, E.J., Thomaz-Filho, A., Campos, D.A. (Eds.), Tectonic Evolution of South America. 31st International Geological Congress, Rio de Janeiro, pp. 231-263.

Dardenne, M.A., 2001. Lithostratigraphic sedimentary sequences of the Vazante Group. In: Misi, A., Teixeira, J.B.G. (Eds.), Proterozoic Base Metal Deposits of Africa and South America. Proceedings of the First IGCP 450 Field Workshop. CNPq/ UNESCO/IUGS, Belo Horizonte and Paracatu (MG), Brazil, pp. $48-50$.

Dardenne, M., Freitas-Silva, F., 1998. Modelos genéticos dos depósitos de $\mathrm{Pb}-\mathrm{Zn}$ nos Grupos Bambuí e Vazante. Proceedings of the Workshop Depósitos Minerais Brasileiros de Metais Base, Salvador (BA), Brazil, pp. 86-93.

Dardenne, M.A., Freitas-Silva, F.H., 1999. Pb-Zn ore deposits of Bambuí and Vazante Groups in the São Francisco Craton and Brasilia Fold Belt, Brazil. In: Silva, M.G., Misi, A. (Eds.), Base Metal Deposits of Brazil, MME-Brazil, pp. 75-83.

Davis, D.W., Lowenstein, T.K., Spencer, R.J., 1990. Melting behavior of fluid inclusions in laboratory-grown halite crystals in the systems $\mathrm{NaCl}-\mathrm{H}_{2} \mathrm{O}, \mathrm{NaCl}-\mathrm{KCl}-\mathrm{H}_{2} \mathrm{O}, \mathrm{NaCl}-\mathrm{MgCl}_{2}-\mathrm{H}_{2} \mathrm{O}$ and $\mathrm{NaCl}-\mathrm{CaCl}_{2}-\mathrm{H}_{2} \mathrm{O}$. Geochimica et Cosmochimica Acta 54, $591-601$.

Dominguez, J.M.L., Misi A. (Eds.), 1993. Cráton do São Francisco. Sociedade Brasileira de Geologia, Sociedade Brasileira de Geologia (SBG, Bahia-Sergipe section), Superintendência de Geologia e Mineração (SGM) and Conselho Nacional de Desenvolvimento Científico e Tecnológico (CNPq), Salvador (BA), Brazil, 215 pp.

Fehn, U., 1985. Postmagmatic convection related to high heat production in granites of southeastern England: a theoretical study. In: Halls, C. (Ed.), High Heat Production (HHP) Granites, Hydrothermal Circulation and Ore Genesis. Institution of Mines and Metallurgy, London, pp. 99-112.

Fehn, U., Cathles, L.M., Holland, H.D., 1978. Hydrothermal convection and uranium deposits in abnormally radioactive plutons. Economic Geology 73, 1556-1566.

Franca-Rocha, W.J.S., 2001. Modelagem Metalogenética da Bacia de Irecê por meio de Sistema de Informações Geográficas (SIG). Unpublished PhD thesis, Federal University of Bahia (Brazil), 350 pp.

Franca Rocha, W.J.S., Misi, A., 1993. Estilo tectônico associado às mineralizações do tipo SEDEX nas coberturas do Proterozóico Médio do Craton do São Francisco. Proceedings of the II Simpósio Sobre o Craton do São Francisco, Sociedade Brasileira de Geologia, Sociedade Brasileira de Geologia 
(SBG, Bahia-Sergipe section), Superintendência de Geologia e Mineração (SGM) and Conselho Nacional de Desenvolvimento Científico e Tecnológico (CNPq), Salvador, BA, pp. 340-343.

Freitas Silva, F.H., Dardenne, M.A., 1997. $\mathrm{Pb} / \mathrm{Pb}$ isotopic patterns of galenas from Morro do Ouro (Paracatu Formation), Morro Agudo/Vazante (Vazante Formation) and Bambuí Group deposits. South American Symposium on Isotope Geology, Campos do Jordão (SP), Extended Abstracts, pp. 118-120.

Gomes, A.S.R., 1998. As mineralizações de sulfetos de Pb-Zn de Nova Redenção, Bacia de Una-Utinga, Bahia. Dissertação de Mestrado, Curso de Pós-Graduação em Geologia, Universidade Federal da Bahia (UFBA), Salvador (BA), 112 pp.

Goodfellow, W.D., Lydon, J.W., Turner, R.J.W., 1993. Geology and genesis of stratiform sediment-hosted (SEDEX) zinc-lead-silver sulfide deposits. In: Kirkham, R.V., Sinclair, W.D., Thorpe, R.I., Duke, J.M. (Eds.), Mineral Deposits Modelling, Special Paper Geological Association of Canada, vol. 40, pp. 201-251.

Gulson, B.L., 1986. Lead isotopes in mineral exploration. Developments in Economic Geology, vol. 23. Elsevier, New York. 245 pp.

Gupta, M.L., Sharma, S.R., Sundar, A., 1991. Heat flow pattern and lithosphere thickness of Peninsular India. In: Cermak, V., Rybach, R. (Eds.), Exploration of the Deep Continental Crust, Terrestrial Heat Flow and the Lithosphere Structure. SpringerVerlag, Heidelberg, pp. 283-292.

Hitzman, M.W., 1995. Mineralization in the Irish $\mathrm{Zn}-\mathrm{Pb}-(\mathrm{Ba}-\mathrm{Ag})$ orefield. In: Anderson, K.E., Ashton, J., Earls, G., Hitzman, M., Tear, S. (Eds.), Irish Carbonate-Hosted Zn-Pb Deposits, Society of Economic Geologists Guidebook Series, vol. 21, pp. 25-61.

Hitzman, M.W., 1997. Observations from the Vazante zinc mine, Minas Gerais, Brazil. Unpublished report, Companhia Mineira de Metais (CMM), 20 pp.

Iyer, S.S., 1984. A discussion on the lead isotope geochemistry of galenas from the Bambuí Group, Minas Gerais, Brazil. Mineralium Deposita, 19, 132-137.

Iyer, S.S., Hamza, V.M., 1992. Paleo heat flow and paleo heat generation in granulite facies terrains: implications for thermal regimes during metamorphism. Proceedings, Scientific Meeting of the Canadian Geophysical Union (Abstracts), Banff, Canada, p. 41.

Iyer, S.S., Hoefs, J., Krouse, H.R., 1992. Sulfur and lead isotope geochemistry of galenas from the Bambuí Group, Minas Gerais, Brazil: implications for ore genesis. Economic Geology, 87, 437-443.

Iyer, S.S, Babinski, M., Krouse, H.R., Chemale Jr., F., 1995. Highly ${ }^{13} \mathrm{C}$ enriched carbonate and organic matter in the Neoproterozoic sediments of the Bambuí Group, Brazil. Precambrian Research 73, 271-282.

Iyer, S.S., Barbosa, J.S.F., Hamza, V.M., Marinho, V.M., 1996. Temporal variation of radioactivity and radiogenic heat production in Archean granulite facies terrains in São Francisco Craton, Brazil: lead isotope approach. Proceedings XXXIX Congresso Brasileiro de Geologia, Sociedade Brasileira de Geologia, vol. 6. Sociedade Brasileira de Geologia (SBG Bahia-Sergipe section), Salvador (BA), Anais, pp. 308-309.
Iyer, S.S., Babinski, M., Marinho, M.M., Barbosa, J.S.F., Sato, I.M., Salvador, V.L., 1999. Lead isotope evidence for recent uranium mobility in geological formations of Brazil: implications for radioactive waste disposal. Applied Geochemistry 14, 197-221.

Jacobsen, S.B., Kaufman, A.J., 1999. The Sr, C and O isotopic evolution of Neoproterozoic seawater. Chemical Geology 161, 37-57.

Kyle, J.R., Misi, A., 1997. Origin of Zn-Pb-Ag sulfide deposits within Upper Proterozoic phosphate-rich carbonate strata, Irecê Basin, Bahia, Brazil. International Geology Review 39, 383-399.

Li, Y.C., Iyer, S.S., Krouse, H.R., Lange, L.M., Nassichuk, W., Misi, A., 1996. Sulfur isotope microanalysis of natural galenas by laser bombardment. Proceedings XXXIX Congresso Brasileiro de Geologia, Sociedade Brasileira de Geologia, vol. 6. Sociedade Brasileira de Geologia (SBG Bahia-Sergipe section), Salvador, Anais, pp. 535-538.

Macedo, M.H.F., 1982. Les systmes isotopiques $\mathrm{Rb}-\mathrm{Sr}$ et $\mathrm{K}-\mathrm{Ar}$ dans les argiles extraits de sédiments carbonatés. Application à la datation du Protérozoique sédimentaire du Brésil dans les États de Bahia et Santa Catarina. Thse Dr. Ingénieur, Université Louis Pasteur, Strasbourg, France, 119 pp.

Macedo, M.H.F., Bonhomme, M.G., 1984. Contribuição à cronoestratigrafia das Formações Caboclo, Bebedouro e Salitre na Chapada Diamantina (BA) pelos métodos $\mathrm{Rb}-\mathrm{Sr}$ e K-Ar. Revista Brasileira de Geociências 14, 153-163.

Machado, N., Schrank, A., Abreu, F.R., Knauer, L.G., Abreu, P.A.A., 1989. Resultados preliminares da geocronologia $\mathrm{U}-\mathrm{Pb}$ na Serra do Espinhaço Meridional. Proceedings of the $5^{\circ}$ Simpósio de Geologia de Minas Gerais. Sociedade Brasileira de Geologia SBG-MG, Belo Horizonte, Anais, pp. $171-174$.

Marinho, M.M., 1991. La séquence volcano-sédimentaire de Contendas-Mirante et la bordure occidentale du bloc Jequié (Craton du São Francisco, Brésil). Un éxemple de transition Archéen-Protérozoique. Thse Doctorat, Universite Blaise Pascal Clermont Ferrand, France, 388 pp.

Marini, O.J., Fuck, R.A., Danni, J.C.M., Dardenne, M.A., 1981. A evolução tectônica da Faixa Brasília e do seu embasamento. Proceedings of the I Simpósio sobre o Cráton do São Francisco e suas faixas marginais, Sociedade Brasileira de Geologia, Sociedade Brasileira de Geologia (SBG, Bahia-Sergipe section) and Coordenação da Produção Mineral (CPM), Salvador, Anais, pp. $100-115$.

Martins, M., 1999. Análise estratigráfica das seqüências Mesoproterozóicas (borda oeste) e Neoproterozóicas da Bacia do São Francisco. Dissertação de Mestrado (MsC thesis), Instituto de Geociências, Universidade Federal do Rio Grande do Sul. RS, Brazil, 214 pp.

Maruéjol, P., Cuney, M., Fuzikawa, K., Netto, A.M., Poty, B., 1987. The Lagoa Real subalkaline granitic complex, South Bahia, Brazil: a source for uranium mineralization associated with $\mathrm{Na}-\mathrm{Ca}$ metasomatism. Revista Brasileira de Geociências $17,578-594$

Miranda, L.L.F., Monteiro, M.M., Cavalcante, J.C.C., Valle, C.R.O., Silva, J.G., 1976. Projeto Fluorita da Serra do Ramalho. 
Unpublished report, Companhia Baiana de Pesquisa Mineral (CBPM) Salvador, $120 \mathrm{pp}$.

Misi, A., 1976. As sequências Bambuí no Estado da Bahia e as mineralizações de chumbo-zinco associadas. Tese Livre Docência (Professor Thesis), Universidade Federal Da Bahia, Salvador, $80 \mathrm{pp}$.

Misi, A., 1978. Ciclos de sedimentação e mineralizações de Pb$\mathrm{Zn}$ nas sequências Bambuí (Supergrupo São Francisco), Estado da Bahia. Proceedings XXX Congresso Brasileiro de Geologia, Sociedade Brasileira de Geologia, vol. 4. Sociedade Brasileira de Geologia (SBG, Northeast section), pp. $2548-2561$.

Misi, A., 1999. Um modelo de evolução metalogenética para os depósitos de zinco e chumbo hospedados em sedimentos proterozóicos de cobertura do Cráton do São Francisco (Bahia e Minas Gerais). Tese Professor Titular, Universidade Federal da Bahia, Salvador-BA, $151 \mathrm{pp}$.

Misi, A., 2001. Estratigrafia isotópica das seqüências do Supergrupo São Francisco, coberturas neoproterozóicas do Craton do São Francisco: Idade e correlações. In: Martins Neto, M.A., Pinto, C.P. (Eds.), Bacia do São Francisco: Geologia e Recursos Naturais. Sociedade Brasileira de Geologia, SBGMG, pp. 67-92.

Misi, A., Kyle, J.R., 1994. Upper Proterozoic carbonate stratigraphy, diagenesis, and stromatolitic phosphorite formation, Irecê Basin, Bahia, Brazil. Journal of Sedimentary Research. A 64, 299-310.

Misi, A., Veizer, J., 1998. Neoproterozoic carbonate sequences of the Una Group, Irecê Basin, Brazil: chemostratigraphy, age and correlations. Precambrian Research 89, 87-100.

Misi, A., Veizer, J., Kawashita, K., Dardenne, M.A., 1997. The age of the Neoproterozoic carbonate platform sedimentation based on ${ }^{87} \mathrm{Sr} /{ }^{86} \mathrm{Sr}$ determinations, Bambuí and Una Groups, Brazil. I South American Symposium on Isotope Geology, Campos do Jordão, São Paulo, Brazil, Extended, pp. 199-200.

Misi, A., Iyer, S.S.S, Tassinari, C.G.G., Coelho, C.E.S., Kyle, J.R., Franca-Rocha, W.J.S., Gomes, A.S.R., Cunha, I.A., Carvalho, I.G., Conceição Filho, V.M., 1998. Integrated Studies and Metallogenic Evolution of the Proterozoic Sediment-Hosted Pb$\mathrm{Zn}-\mathrm{Ag}$ Sulfide Deposits of the São Francisco Craton, Brazil. In: Proceedings of the Workshop "Depósitos Minerais Brasileiros de Metais Base", Centro de Pesquisa em Geofísica e Geologia (CPGG/UFBA), Campanha de Aperfeiçoamento de Pessoal de Nível Superior (CAPES), Associação para o Desenvolvimento da Indústria Mineral do Brasil (ADIMB) and Sociedade Brasileira de Geologia (SBG, Bahia-Sergipe section), Salvador, Anais, pp. 94-101.

Misi, A., Iyer, S.S.S., Tassinari, C.E.S., Kyle, C.G.G., Coelho, J.R., Franca-Rocha, W.J.S., Gomes, A.S.R., Cunha, I.A., Carvalho, I.G., 1999. Geological and isotopic constraints on the metallogenic evolution of the Proterozoic sedimenthosted $\mathrm{Pb}-\mathrm{Zn}(\mathrm{Ag})$ deposits of Brazil. Gondwana Research 2, 47-65.

Misi, A., Iyer, S.S.S, Coelho, C.E.S., Tassinari, C.G.G., Kyle, J.R., Franca-Rocha, W.J.S., Gomes, A.S.R., Cunha, I.A., Toulkeridis, T., Sanches, A.L., 2000. A metallogenic evolution model for the lead-zinc deposits of the Meso and Neoproterozoic basins of the
São Francisco Craton, Bahia and Minas Gerais, Brazil. Revista Brasileira de Geociências 30, 302-305.

Misi, A., Teixeira, J.B.G., Gaucher, C., Remus, M.V.D., Boggiani, P.C., Iyer, S.S.S., 2003. Chemostratigraphic correlation of the Neoproterozoic sequences from South America. IV South American Symposium on Isotope Geology, Salvador (Brazil), Short Papers, vol. 1, pp. 368-371.

Monteiro, M.D., 1989. Projeto Irecê-Lapão, $2^{\text {a }}$ etapa, reprogramação. Unpublished report, Companhia Baiana de Pesquisa Mineral (CBPM), 2 vol. 140 pp.

Monteiro, L.V.S., 1997. Contribuição à gênese das mineralizações de Zn da mina de Vazante, Minas Gerais. Dissertação de Mestrado (MsC), Universidade de São Paulo, SP, 159 pp.

Monteiro, L.V.S., Bettencourt, J.S., Spiro, B., Graça, R., Oliveira, T.F., 1999. The Vazante zinc mine, Minas Gerais, Brazil: constraints on fluid evolution and willemite mineralization. Exploration and Mining Geology 8, 21-42.

Moraes Filho, O., Leal, R.A., 1990. Prospecção de Chumbo/Zinco/ Prata no município de Nova Redenção (BA). Proceedings XXXVI Congresso Brasileiro de Geologia, Sociedade Brasileira de Geologia. Sociedade Brasileira de Geologia (SBG, Northeast section), pp. 1407-1501.

Oakes, C.S., 1997. Short discussion of apparent low eutectic temperature observations. Fluid Inclusions Web site: http:// www.geology.wisc.edu/ pbrown/fi.html (accessed June 1997).

Oakes, C.S., Bodnar, R.J., Simonson, J.M., 1990. The system $\mathrm{NaCl}-\mathrm{CaCl}_{2}-\mathrm{H}_{2} \mathrm{O}$. I. The hosts liquids at 1 atm total pressure. Geochimica et Cosmochimica Acta 54, 603-610.

O'Connor, P.J., 1986. Uranium mineralization in the Irish Caledonides. In: Andrew, C.J., Crowe, R.W.A., Finlay, S., Pennel, W.M., Fyfe, J.F. (Eds.), Geology and Genesis of Mineral Deposits in Ireland. Association Economic Geology, Dublin, pp. 157-175.

Ohmoto, H., Rye, R.O., 1979. Isotopes of sulphur and carbon. In: Barnes, H.L. (Ed.), Geochemistry of Hydrothermal Ore Deposits, 2nd ed. Holt, Rinehart and Winston, New York, pp. $509-567$.

Oxburgh, E.R., 1981. Heat flow and differences in lithosphere thickness. Philosophical Transactions of the Royal Society London. A 301, 337-346.

Pedrosa Soares, A.C., Dardenne, M.A., Hasui, Y., Castro, F.D.C., Carvalho, M.V.A., Reis, A.C., 1994. Mapa Geológico do Estado de Minas Gerais e Nota Explicativa. Secretaria de Recursos Minerais, Hídricos e Energéticos, Companhia Mineradora de Minas Gerais (COMIG), 97 pp.

Pedrosa Soares, A.C., Cordani, U.G., Nutman, A., 2000. Constraining the age of Neoproterozoic glaciation in eastern Brazil: first U-Pb (SHRIMP) data for detrital zircons. Revista Brasileira de Geociências 30, 58-61.

Porada, H., 1989. Pan-African rifting and orogenesis in southern to Equatorial Africa and eastern Brazil. Precambrian Research 44, $103-136$.

Robertson, J.R., 1963. Geology of the lead-zinc deposits in the "município" de Januária, State of Minas Gerais, Brazil. U.S. Geological Survey Bulletin, 1110-B (110 pp.)

Romagna, G., Costa, R.R., 1988. Jazida de zinco e chumbo de Morro Agudo, Paracatú, Minas Gerais. In: Schobbenhaus, C., Coelho C.E. (Eds.), Principais Depósitos Minerais do Brasil. 
Departamento Nacional da Produção Mineral (DNPM) and Companhia Vale do Rio Doce (CVRD), vol. 3, pp. 111-121.

Sangster, D.F., Savard, M.M., Kontak, D.J., 1998. A genetic model for mineralization of Lower Windsor (Viséan) carbonate rocks of Nova Scotia, Canada. Economic Geology 93, 932-952.

Santos Pinto, M.A., 1996. Le Récyclage de la croûte continentale archéenne. Exemple du Bloc du Gavião, Bahia, Brésil, Mémoires des Géosciences, vol. 75. Univ. Rennes, France. 193 pp.

Schobbenhaus, C., Campos, D.A., Derze, G.R., Asmus, H.E., 1981. Geological map of Brazil, scale 1:2.500.000. Departamento Nacional da Produção Mineral, Divisão de Geologia e Mineração (DNPM/DGM), Brasília.

Silva, M.G., 1992. Evidências isotópicas e geocronológicas de um fenômeno de acrescimento crustal Transamazônico no Cráton do São Francisco, Estado da Bahia. Proceedings of the XXXVII Congresso Brasileiro de Geologia, vol. 2. Sociedade Brasileira de Geologia, SBG-SP, Anais, pp. 181-182.
Thomaz Filho, A., Kawashita, K., Cordani, U.G., 1998. A origem do grupo Bambuí no contexto da evolução geotectônica e de idades radiométricas. Anais da Academia Brasileira de Ciências 70, 527-548

Turpin, L., Maruéjol, P., Cuney, M., 1988. U-Pb, Rb-Sr and Sm$\mathrm{Nd}$ chronology of granitic basement, hydrothermal albitites and uranium mineralization (Lagoa Real, South Bahia Brazil). Contributions to Mineralogy and Petrology 98, 139-147.

Ussami, N., 1993. Estudos geofísicos no Cráton do São Francisco: estágio atual e perspectivas. In: Dominguez, J.M.L., Misi A. (Eds.), O Cráton do São Francisco. Sociedade Brasileira de Geologia, Sociedade Brasileira de Geologia (SBG, BahiaSergipe section), Superintendência de Geologia e Mineração (SGM) and Conselho Nacional de Desenvolvimento Científico e Tecnológico (CNPq), Salvador, BA, pp. 35-43.

Zartman, R.E., Doe, B.R., 1981. Plumbotectonics - the model. Tectonophysics $75,135-162$. 